\section{Pacific Northwest} National Laboratory

Operated by Battelle for the

U.S. Department of Energy

\title{
Groundwater Monitoring Plan for the Hanford Site 216-B-3 Pond RCRA Facility
}

\author{
D. B. Barnett \\ R. M. Smith \\ C. J. Chou
}

November 2000

\author{
Prepared for the U.S. Department of Energy \\ under Contract DE-AC06-76RL01830
}




\title{
DISCLAIMER
}

This report was prepared as an account of work sponsored by an agency of the United States Government. Reference herein to any specific commercial product, process, or service by trade name, trademark, manufacturer, or otherwise does not necessarily constitute or imply its endorsement, recommendation, or favoring by the United States Government or any agency thereof, or Battelle Memorial Institute.

\author{
PACIFIC NORTHWEST NATIONAL LABORATORY \\ operated by \\ BATTELLE \\ for the \\ UNITED STATES DEPARTMENT OF ENERGY \\ under Contract DE-AC06-76RL01830
}

\author{
Printed in the United States of America \\ Available to DOE and DOE contractors from the \\ Office of Scientific and Technical Information, P.O. Box 62, Oak Ridge, TN 37831; \\ prices available from (615) 576-8401.
}

Available to the public from the National Technical Information Service, U.S. Department of Commerce, 5285 Port Royal Rd., Springfield, VA 22161

This document was printed on recycled paper. 


\title{
Groundwater Monitoring Plan for the Hanford Site 216-B-3 Pond RCRA Facility
}

\author{
D. B. Barnett \\ R. M. Smith \\ C. J. Chou
}

November 2000

Prepared for

the U.S. Department of Energy

under Contract DE-AC06-76RL01830

Pacific Northwest National Laboratory

Richland, Washington 99352 


\section{Summary}

The 216-B-3 Pond was a series of ponds used for disposal of liquid effluent from past Hanford production facilities. In operation since 1945, the B Pond System has been a RCRA facility since 1986, with RCRA interim-status groundwater monitoring in place since 1988. In 1994 the expansion ponds of the facility were cleaned closed, leaving only the main pond and a portion of the 216-B-3-3 ditch as the currently regulated facility.

In 1990, groundwater monitoring at B Pond was elevated from "detection" to assessment status because total organic halides and total organic carbon were found to exceed critical means in two wells. Groundwater quality assessment, which ended in 1996, failed to find any specific hazardous waste contaminant that could have accounted for the isolated occurrences of elevated total organic halides and total organic carbon. Hence, the facility was subsequently returned to detection-level monitoring in 1998.

Exhaustive groundwater analyses during the assessment period indicated that only two contaminants, tritium and nitrate, could be positively attributed to the B Pond System, with two others (arsenic and iodine-129) possibly originating from B Pond. Chemical and radiological analyses of soil at the main pond and 216-B-3-3 ditch has not revealed significant contamination.

Based on the observed, minor contamination in groundwater and in the soil column, three parameters were selected for site-specific, semiannual monitoring; gross alpha, gross beta, and specific conductance. Total organic halides and total organic carbon are included as constituents because of regulatory requirements. Arsenic, iodine-129, nitrate, and tritium will be monitored under the aegis of Hanford site-wide monitoring.

Although the B Pond System is not scheduled to advance from RCRA interim status to final status until the year 2003, a contingency plan for an improved monitoring strategy, which will partially emulate final status requirements, will be contemplated before the official change to final status. This modification will allow a more sensible and effective screening of groundwater for the facility. 


\section{Acknowledgments}

The authors extend their appreciation to reviewers M. J. Hartman, S. P. Luttrell, and D. R. Newcomer for valuable contribution to the quality of the document. Thanks are also extended to L. M. Andor and K. R. Neiderhiser for preparation of the document, and to J. T. Rieger, D. E. Brunson, and C. A. Newbill for graphics support. 


\title{
Acronyms and Abbreviations
}

\author{
$\mu \mathrm{g} / \mathrm{L}$ \\ micrograms per liter \\ CERCLA \\ Comprehensive Environmental Response, Compensation, and Liability Act of 1980 \\ CFEST \\ $\mathrm{CM}$ \\ Coupled Fluid, Energy, and Solute Transport (model) \\ DOE \\ critical mean \\ $\mathrm{DOE} / \mathrm{RL}$ \\ U.S. Department of Energy \\ DWS \\ U.S. Department of Energy/Richland Operations Office \\ Ecology \\ drinking water standards \\ EPA \\ $\mathrm{ft} / \mathrm{d}$ \\ Washington State Department of Ecology \\ HEIS \\ U.S. Environmental Protection Agency \\ $\mathrm{m} / \mathrm{d}$ \\ feet per day \\ Hanford Environmental Information System \\ MDA \\ meters per day \\ minimum detectable activities \\ $\mathrm{mg} / \mathrm{kg}$ \\ $\mathrm{mg} / \mathrm{L}$ \\ milligrams per kilogram \\ MTCA \\ milligrams per liter \\ NTU \\ Model Toxics Control Act \\ $\mathrm{OU}$ \\ $\mathrm{pCi} / \mathrm{g}$ \\ $\mathrm{pCi} / \mathrm{L}$ \\ PNNL \\ POC \\ PUREX \\ nephlometric turbidity unit \\ operable unit \\ picocuries per gram \\ picocuries per liter \\ Pacific Northwest National Laboratory \\ point of compliance \\ QA/QC \\ Plutonium-Uranium Extraction (plant) \\ RCRA \\ quality assurance/quality control \\ SVOC \\ Resource Conservation and Recovery Act \\ TEDF \\ TOC \\ TOX \\ semivolatile organic compound \\ 200 Areas Treated Effluent Disposal Facility \\ total organic carbon \\ total organic halides \\ TSD \\ treatment, storage, or disposal \\ VOC \\ volatile organic compound \\ WAC \\ Washington Administrative Code
}




\section{Contents}

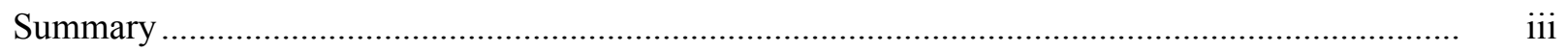

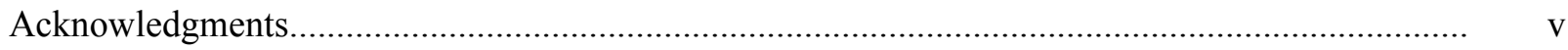

Acronyms and Abbreviations .................................................................................. vii

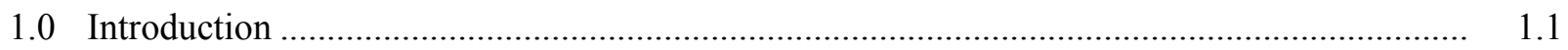

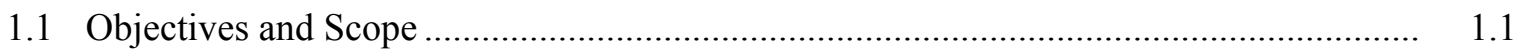

1.2 Facility Description and History of Operation ............................................................... 1.3

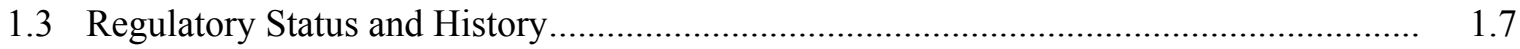

1.4 History of RCRA Groundwater Monitoring at the B Pond ......................................... 1.8

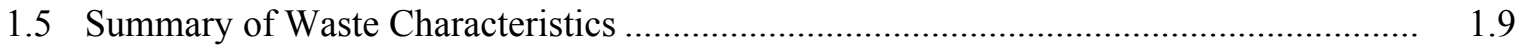

1.6 Results of Soil Contamination Characterization .......................................................... 1.10

1.6.1 Early Phases of Soil Investigation: 1989-1992 _................................................ 1.11

1.6.2 Recent Investigations for 200-CW-1 OU: 1999 ............................................. 1.11

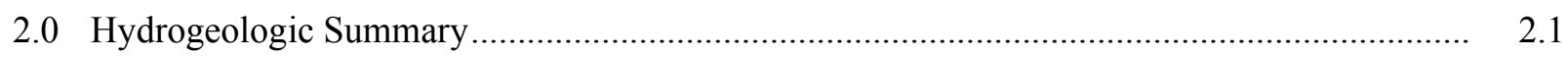

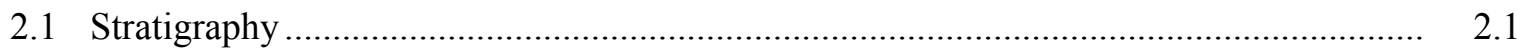

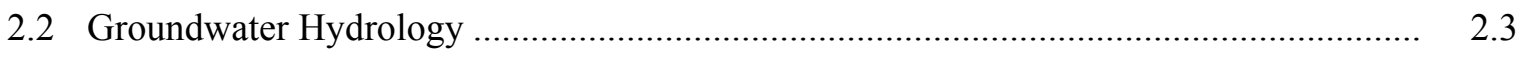

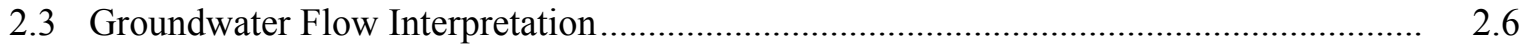

2.3.1 Status of the Groundwater Monitoring Network .............................................. 2.7

3.0 Summary of Groundwater Chemistry and Groundwater Quality Assessment ..................... 3.1

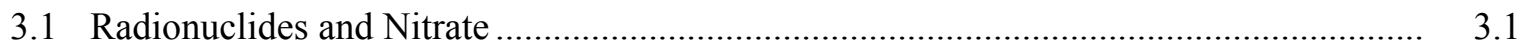

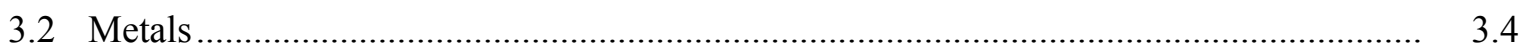

3.3 Total Organic Carbon and Total Organic Halides...................................................... 3.6 


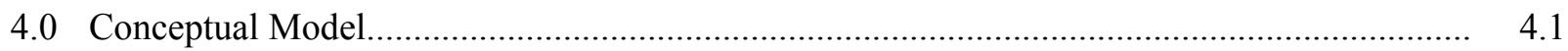

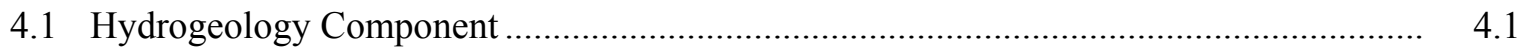

4.2 Groundwater Chemistry Component.................................................................. 4.1

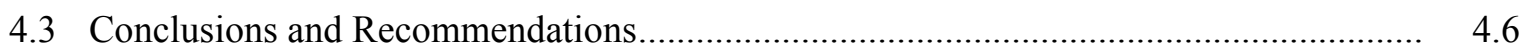

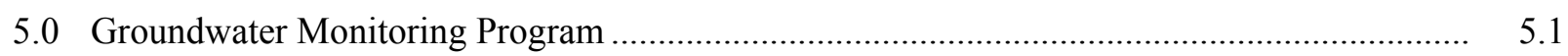

5.1 RCRA Interim-Status Regulatory Overview......................................................... 5.1

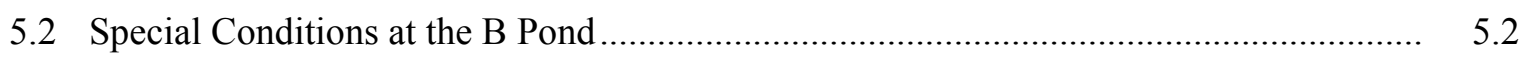

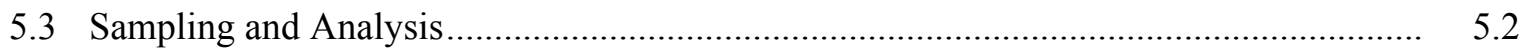

5.4 Point of Compliance and Well Network ............................................................... 5.4

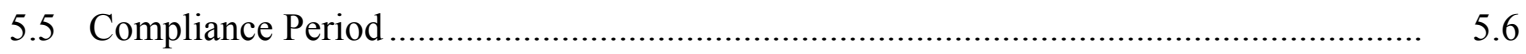

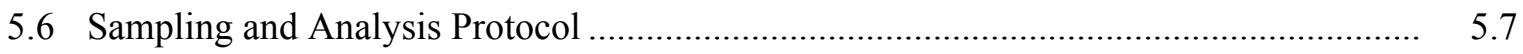

5.7 Quality Assurance and Quality Control ............................................................ 5.7

5.8 Data Management, Evaluation, Interpretation, and Reporting .................................. 5.7

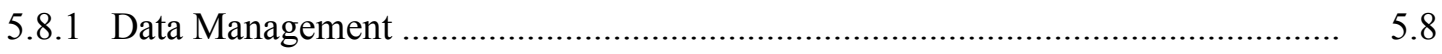

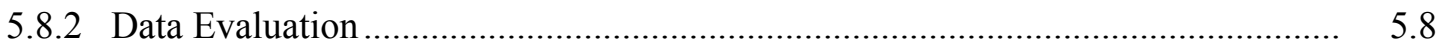

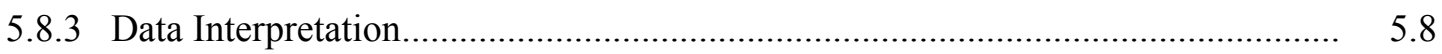

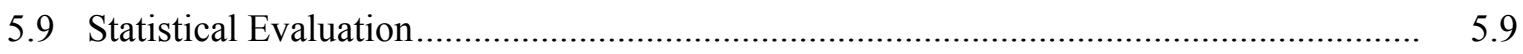

5.10 Contingency for Alternative Monitoring Approach and Statistical Methods.................. 5.10

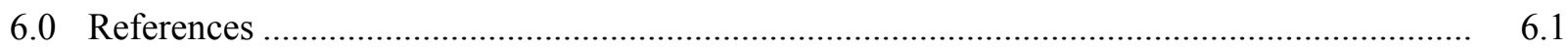

Appendix A - Historical Monitoring Well Network Information Summary for the B Pond ............ A.1

Appendix B - Hydrographs and Serviceability Information for Historical and Current

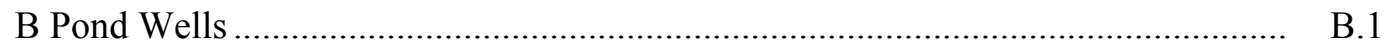

Appendix C - Well Lithologic Logs and Construction Details .............................................. C.1 


\section{Figures}

1.1 Location of the 216-B-3 Pond Facility and the Hanford Site.

1.2 Location and Configuration of the B Pond Facility and All Former Monitoring Wells Used for the Facility

1.3 Timeline of Significant Events at the B Pond Facility

1.4 Annual and Cumulative Discharge Volumes to the B Pond System, 1945 to 1997.

2.1 Generalized Stratigraphic Column for the B Pond Area

2.2 March 2000 Water-Table Map for the Confined and Unconfined Aquifer Near B Pond and Geometry of Significant Hydrostratigraphic Units.

2.3 Schematic Cross-Section of the B Pond Area Showing General Hydrostratigraphic Relationships and the Effects of Historical Discharges by B Pond and TEDF

3.1 Plots for Tritium and Nitrate at the B Pond Facility in Wells Illustrating Significant Trends

3.2 Trend Plots for Gross Alpha and Gross Beta in Selected B Pond Wells

3.3 Representative Trends for Specific Conductance at B Pond

3.4 Map of the B Pond Area Showing Long-Term Average Values for Specific Conductance .....

4.1 Hypothetical Hydrostratigraphic Relationships and Effluent Flow Patterns in the Vicinity of B Pond.

4.2 Tritium Maxima in B Pond and Vicinity Wells Showing Extent of Tritium Migration in the Confined Aquifer.

4.3 Major Ion Chemistry in Wells Completed in the Ringold Unit 9 in the Vicinity of B Pond 


\section{Tables}

3.1 Summary of Groundwater Results for Constituents of Potential Significance at the

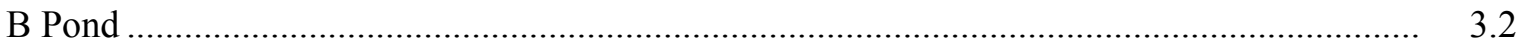

5.1 Constituent List for the B Pond Facility .................................................................. 5.3

5.2 Revised B Pond Groundwater Monitoring Well Network............................................. 5.6

5.3 Critical Means for 16 Comparisons-Background Contamination Indicator Parameter

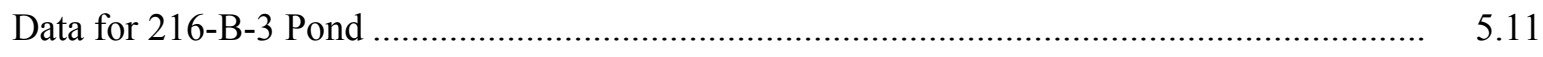




\subsection{Introduction}

The 216-B-3 pond system (B Pond) is a regulated wastewater disposal facility for operations in the 200 East Area of the Hanford Site (Figure 1.1). The B Pond has been a Resource Conservation and Recovery Act (RCRA) hazardous waste facility since 1986, when a RCRA (Part A) permit application was submitted to the Washington State Department of Ecology (Ecology). Groundwater monitoring has been conducted in accordance with RCRA interim status requirements since 1988, and the current detection-level monitoring program is described by Sweeney (1995). In 1998, the Groundwater Monitoring Plan for the Hanford Site 216-B-3 Pond RCRA Facility (Barnett and Chou 1998) was released to address the change in monitoring strategy derived from the 1997 work. The 1998 groundwater monitoring strategy included a plan for intra-well monitoring and more accurate statistical methods for evaluating groundwater data. However, inflexibility in the existing RCRA groundwater monitoring requirements administered by state regulators led to an impasse to applying the new strategy. The plan presented here proposes a revised well network and list of constituents that reflects the current interpretation of groundwater flow and potential for contamination occurrence. The plan also addresses regulatory constraints and requirements, while proposing a contingency for more appropriate groundwater monitoring to be effected in a follow-on effort.

\subsection{Objectives and Scope}

The purpose of this document is to establish a groundwater monitoring program for the B Pond that will effectively address recent changes in the groundwater flow directions, and incorporate the sum of knowledge about the potential for contamination originating from the facility. The program is based primarily on groundwater monitoring requirements for a RCRA facility in interim-status detection (detection level), but also presents an alternative approach using intrawell monitoring and control chart comparisons for site-specific constituents. This approach is necessary because of the unique hydrogeologic conditions and history of the site. Thus, this document describes the implementation of an updated, conventional RCRA groundwater monitoring plan using upgradient-downgradient well comparisons of indicator parameters, and includes a contingency for applying intra-well data comparisons of key constituents as an eventual replacement for the conventional plan. Pending regulator approval, the contingency plan will supersede the conventional plan, based on a schedule that will be developed during FY 2001 (see Section 5.10). This approach provides for a more rational and practical application of groundwater monitoring at the B Pond rather than simply defaulting to regulatory minimum requirements. This document also summarizes past and current groundwater monitoring at the B Pond and presents background information based on findings from the 1997 study, a conceptual model derived from soil and vadose zone characterization, and the most recent evaluations of groundwater hydrology and chemistry at the site. The groundwater monitoring plan in Section 5.0 supersedes the existing plan of Sweeney (1995). 


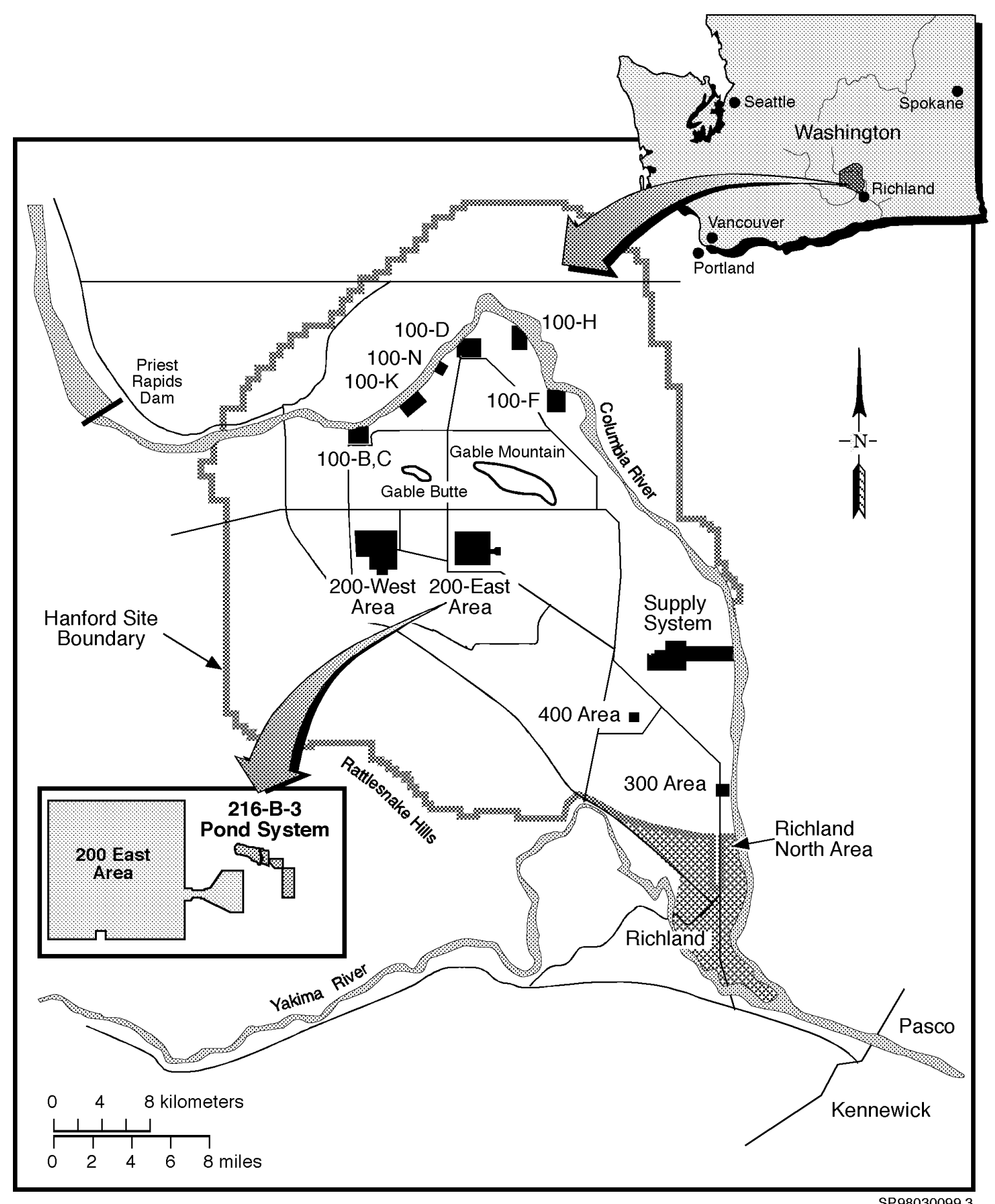

Figure 1.1. Location of the 216-B-3 Pond Facility and the Hanford Site 


\subsection{Facility Description and History of Operation}

The B Pond is located east of the 200 East Area and consisted of a main pond and three expansion ponds, all constructed for wastewater disposal (Figure 1.2). The B Pond began receiving effluent in 1945 at the site of the main pond. The main pond (initially termed the "B-3 Pond") was located in a natural topographic depression, diked on the eastern margin, covered approximately 14.2 hectares ( 35 acres), and had a maximum depth of $\sim 6.1$ meters (20 feet). Three expansion ponds (216-B-3A [3A], 216-B-3B [3B], and 216-B-3C [3C] expansion ponds) were placed into service in 1983, 1984, and 1985, respectively. The $3 \mathrm{~A}$ and $3 \mathrm{~B}$ expansion ponds are about 4.5 hectares $(11 \mathrm{acres})$ in size, and the $3 \mathrm{C}$ expansion pond is approximately 16.6 hectares (41 acres). Water discharged to these ponds, primarily the main and $3 \mathrm{~A}$ ponds, infiltrated into the ground and artificially recharged the underlying aquifer. An open spillway connected the main and $3 \mathrm{~A}$ ponds. The 216-B-3-1, B-3-2, B-3-3, and A-29 ditches were used to convey effluent from the producing facilities in the 200 East Area to the main pond. Details of the operation of these ponds and ditches are presented in DOE/RL (1993a).

Beginning in April 1994, discharges to the main pond/3A pond ceased, and all effluents were rerouted to the $3 \mathrm{C}$ expansion pond via a pipeline. Also during 1994, the main pond and B-216-B-3-3 ditch (B-3-3 ditch) were filled with clean soil, and all vegetation was removed from the perimeter and included with the fill soil, as part of interim stabilization activities. Just prior to the diversion of the effluent from the main pond, the 3A, 3B, and 3C expansion ponds were clean closed under RCRA. This determination indicates that no identifiable waste remains in the closed facilities. Hence, only the main pond and an adjoining part of the B-3-3 ditch require groundwater monitoring under RCRA requirements.

In June 1995, portions of the effluent stream were rerouted to the 200 Areas Treated Effluent Disposal Facility ([TEDF]; formerly known as "Project W-049H"). The remaining streams were diverted from the 3C Expansion Pond to the TEDF in August 1997, thus ending all operation of the B Pond. Historic effluent feeds are described in greater detail by DOE/RL (1993a) and Johnson et al. (1995). Figure 1.3 illustrates the sequence of important events surrounding operation of the B Pond.

In the past, the B Plant steam condensate and chemical sewer were discharged to the B Pond (primarily the main pond). Potential contaminants contained within past waste streams, which may have entered the groundwater, are discussed in DOE/RL (1993a) and are summarized in Section 1.5. The last chemical waste discharge to the B Pond (main pond) occurred in 1987. Tritium was discharged to the facility throughout its operational life, though recent quantities have been extremely small.

Discharge volumes to the B Pond were at a maximum during 1988 (Figure 1.4). Total discharge to the facility since 1945 is estimated to have exceeded $1.0 \mathrm{E}+12$ liters. For the first 8 months of 1997 , until operation ceased, the $3 \mathrm{C}$ pond received 487,000,000 liters (130,000,000 gallons) of effluent. The $3 \mathrm{C}$ Pond is still maintained as an overflow contingency facility for the TEDF. As of July 2000, only one diversion of 12 hours duration, in June 1999, has been sent to the 3C Pond. 


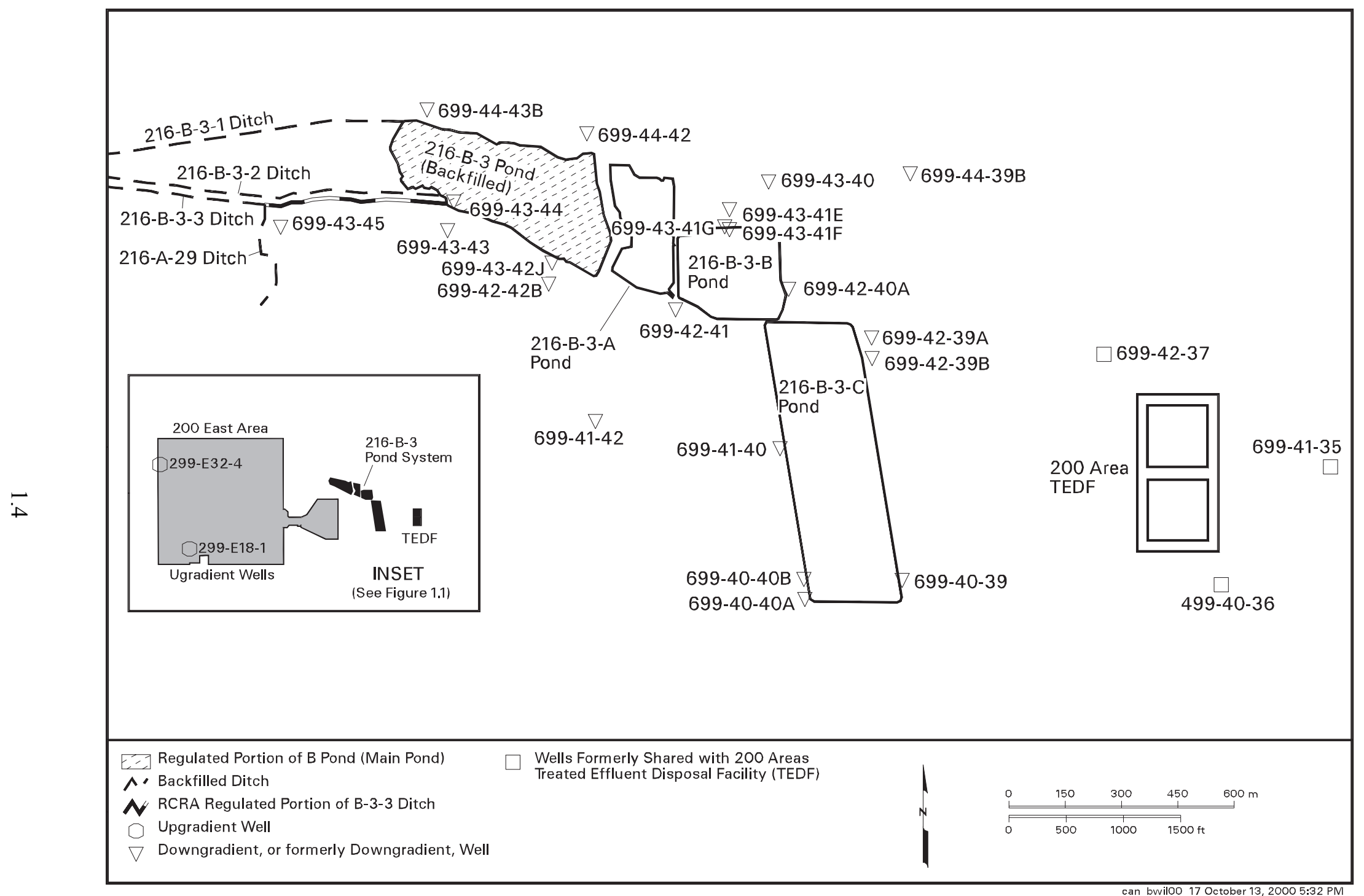

Figure 1.2. Location and Configuration of the B Pond Facility and All Former Monitoring Wells Used for the Facility 


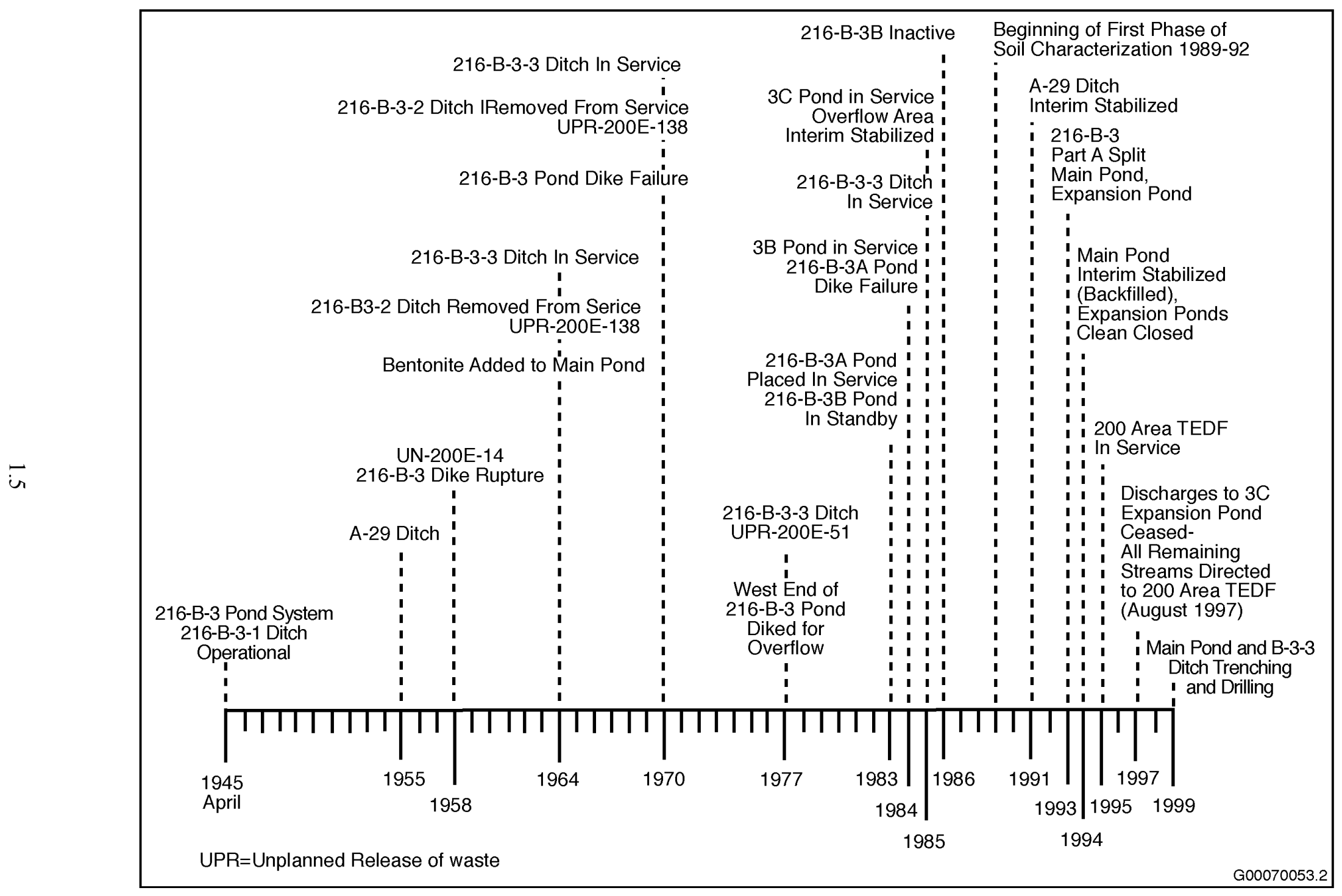

Figure 1.3. Timeline of Significant Events at the B Pond Facility 


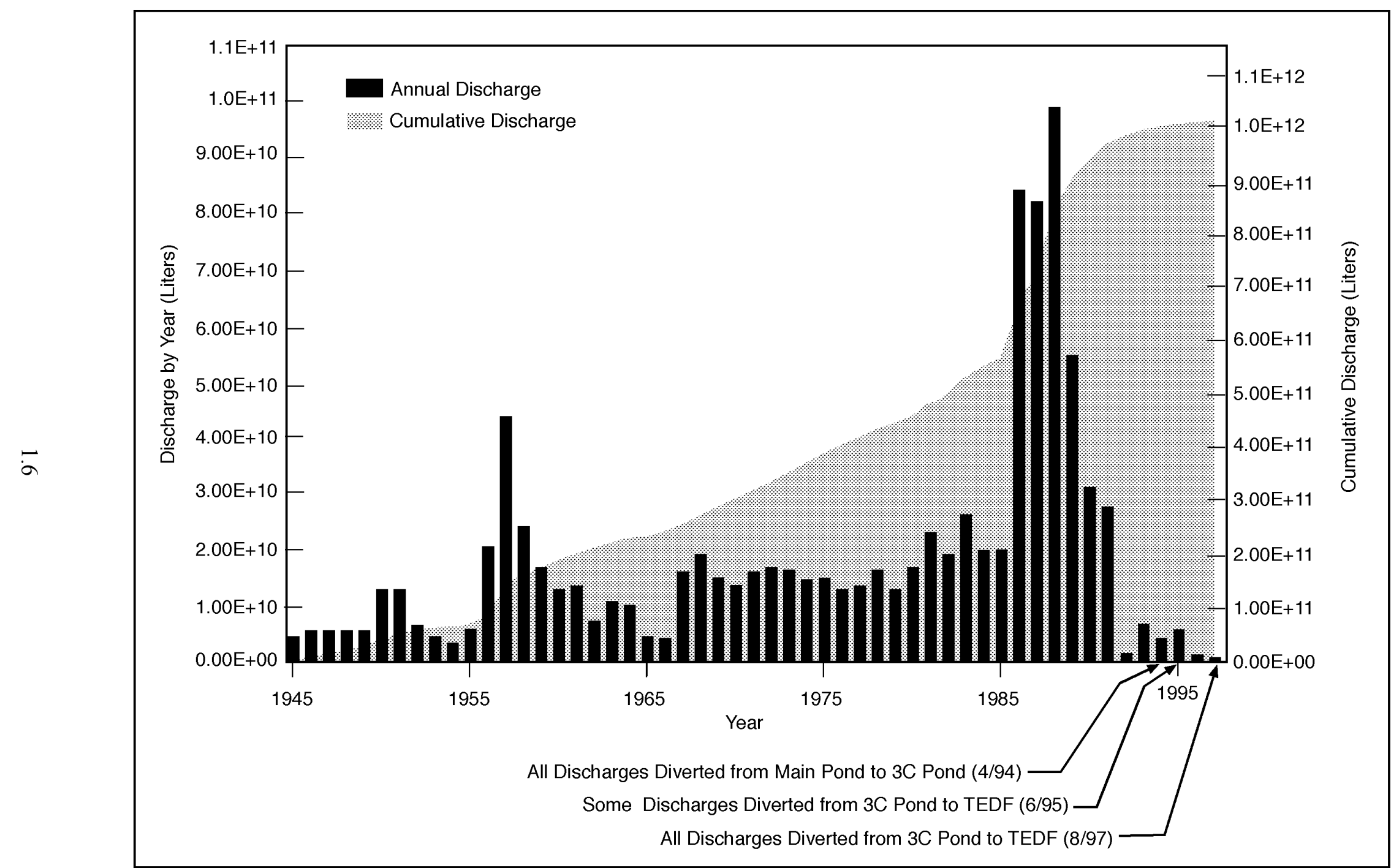

SG98030099.10

Figure 1.4. Annual and Cumulative Discharge Volumes to the B Pond System, 1945 to 1997 


\subsection{Regulatory Status and History}

During 1993, the original RCRA Part A permit application (DOE/RL 1990) was modified to distinguish the three expansion ponds (3A, 3B, and 3C) from the main pond and a segment of the B-3-3 ditch (DOE/RL 1993a). This change allowed clean closure of the expansion ponds to meet the Hanford Federal Facility Agreement and Consent Order, Milestone M-17-10 (Ecology et al. 1998). The expansion ponds were also included in a RCRA facility investigation/corrective measures study for the 200-CW-1 operable unit (formerly known as the 200-BP-11 operable unit) (DOE/RL 1994). The portion of the B-3-3 ditch west of its junction with the 216-A-29 ditch, and the B-3-1 and B-3-2 ditches are RCRA past-practice facilities and are not included in the B Pond treatment, storage, or disposal (TSD) unit. Thus, the only portions of the original facilities that are addressed under this RCRA groundwater monitoring plan are the main pond and the segment of the B-3-3 ditch between the main pond and the 216-A-29 ditch.

The Ground Water Impact Assessment Report for the 216-B-3 Pond System (Johnson et al. 1995) was released as a requirement of the Hanford Federal Facility Agreement and Consent Order (Ecology et al. 1998) Milestones M-17-00A and M-17-00B. This report addressed the impact of continued discharge of uncontaminated water to the 216-B-3C expansion pond of the B Pond until 1997, and concluded the following:

- Based on groundwater modeling, little change was predicted in the existing flow regime beneath the pond and in the vicinity of the 200 East Area until June 1997 (see Section 2.2.2).

- Remobilization of potential contamination beneath the main pond to groundwater, due to $3 \mathrm{C}$ pond operation, is unlikely.

- Effects on existing groundwater contamination plumes from effluent discharge until 1997 would be negligible.

These findings helped support the $3 \mathrm{C}$ pond mission as a contingency basin for the TEDF, and, thus far, these predictions appear to have proven correct.

The B Pond also falls within the 200-CW-1 source operable unit and the BP-5 and P0-1 groundwater operable units, which are regulated under the Comprehensive Environmental Response, Compensation, and Liability Act of 1980 (CERCLA) program (DOE/RL 1994).

Activities conducted as part of the closure process for the expansion ponds included soil and sediment sampling, interim stabilization of the main pond and B-3-3 ditch, and decontamination and removal of structures and associated fixed equipment (DOE/RL 1993b). Soil and sediment sampling activities in support of closure were conducted in three phases from 1989 through 1992. The most recent, and probably final characterization of the vadose zone at the B Pond occurred during September 1999 when one deep borehole and ten trenches were excavated in the main pond and B-3-3 ditch (Cearlock et al. 2000). The results of these investigations substantiated that soil contamination is generally shallow and of low concentrations. The results of soil investigation are summarized in Section 1.6. 


\subsection{History of RCRA Groundwater Monitoring at the B Pond}

RCRA groundwater monitoring of the B Pond began in 1988 with an interim status detection level program. The initial program is described by Luttrell (1989). Groundwater monitoring was changed from a RCRA detection program to an assessment program in 1990 because of elevated levels of total organic halides and total organic carbon in two downgradient wells. A groundwater quality assessment plan (Harris 1990) was submitted to Ecology in May 1990. The results of groundwater quality assessment, which concluded in 1996, are reported by Barnett and Teel (1997), and are summarized in Section 4.0. The most recent groundwater monitoring plan is found in Sweeney (1995), as amended by Interim Change Notice.

A list of the wells in the current and former B Pond RCRA groundwater monitoring networks (see Figure 1.2) and the dates of construction are shown in Appendix A. Downgradient wells were installed from 1988 through 1992. Ten of the network wells are constructed with screens at the water table. The remaining 15 wells are screened at deeper levels in the aquifer. Four well clusters, involving nine wells, are situated to provide information on vertical components of hydraulic gradient in the aquifer and potential contaminant distribution.

Both upgradient wells were selected to be as near the B Pond as possible, yet outside the hydrologic influence of the facility (see Section 2.2). The maximum number of wells (25) was monitored from 1993 until late 1995. The number of wells in the network was reduced to 13 in 1995 to eliminate redundancy and focus resources on additional hydrochemical analyses in the remaining wells. Three of the wells no longer in the B pond network are part of the TEDF groundwater monitoring network. These three wells were monitored for informational purposes only and were not part of the RCRA-regulated B Pond network. In 1996, one of two upgradient wells (299-E18-1) was dropped from the network to reduce redundancy. This well was part of the 2101-M pond facility, which was clean closed. The other upgradient well, 299-E32-4, was shared with the low-level burial grounds facility in the 200 East Area (see Figure 1.2).

In 1998, the groundwater monitoring program at the B Pond was returned to contamination detection level monitoring from assessment monitoring. From late 1998 through early 2000, the network was restructured (existing wells were dropped or added) to adjust for changes in the groundwater flow direction, to compensate for the drying of some wells, and to further reduce redundancy in monitoring locations. The site-specific constituent list of groundwater analyses was also amended to more accurately address the potential contaminants at this site.

In September 1999, a new downgradient well (699-43-44) was installed to fill a gap in coverage left by the drying of well 699-43-43 and to compensate for changes in groundwater flow directions beneath B Pond. The well was completed in conjunction with the vadose zone contaminant characterization for the CERCLA 200-CW-1 Operable Unit. 


\subsection{Summary of Waste Characteristics}

The B Pond received effluent from several 200 East Area facilities. Descriptions of waste sources, waste streams, process information, and unplanned releases involving the B Pond are described in several related documents (e.g., WHC 1989, WHC 1990a, DOE/RL 1993a, DOE 1993b, DOE/RL 1994, and most recently DOE/RL 2000). Some of the reports are reiterative, while others improve on previous information. The salient points from these reports, as they apply to potential contamination of the B pond soils or groundwater, are summarized here.

Several sources of wastewater and effluent have contributed to B Pond discharges during the facility's operational life. By far, the greatest volume consisted of raw Columbia River water. Discharges from these sources were routine, scheduled releases and a few unplanned releases. The most important of the sources of effluent include

- Plutonium-Uranium Extraction (PUREX) Plant chemical sewer

- B Plant chemical sewer

- 242-A evaporator steam condensate and cooling water

- 244-AR vault cooling water

- 284-E powerplant wastewater

- 241-A tank farm cooling water

- B Plant cooling water

- PUREX Plant cooling water.

Waste streams from these facilities were conveyed to the main pond through a system of ditches, and pipelines. From the PUREX Plant, the main pond received mixed wastes via the 216-A-29 ditch and the PUREX cooling water line. The B Plant facilities conveyed effluent via the 216-B-2-1, 216-B-2-2, and 216-B-2-3 ditches to the 216-B-3-1, 216-B-3-2, and B-3-3 ditches, which, in turn, emptied into the main pond. These ditches were decommissioned and stabilized (backfilled) over a period of time (see Figure 1.3), mostly as a result of unplanned releases of dangerous wastes (DOE/RL 1993b). During the final few years of operation, mostly uncontaminated water (essentially river water and condensate with some tritium) from the B Plant and PUREX facilities was conveyed to the main pond, 3A, and 3C ponds via closed pipelines. Of the eight streams listed above, the largest actual and potential contributors of dangerous waste to the B Pond are the PUREX and B Plant chemical sewers.

Corrosive hazardous wastes, such as nitric and sulfuric acid were routinely discharged to the B Pond via the ditches, although attempts were made to neutralize these wastes before they were discharged. 
Other volumetrically important chemicals discharged to the B Pond include cadmium nitrate, ammonium fluoride, ammonium nitrate, and sodium hydroxide. Sulfuric acid and sodium hydroxide were the most frequently discharged hazardous wastes. An unplanned release containing 51 kilograms (112 pounds) of cadmium nitrate from the PUREX chemical sewer was sent to the B Pond in 1977 (DOE/RL 1994). DOE/RL (1993b) reports this release contained only 15 kilograms (33 pounds) of cadmium nitrate. While Westinghouse Hanford Company (WHC 1990) states that $>172,000$ kilograms of cadmium from cadmium nitrate spills has been sent to the B Pond, DOE/RL (1993b) accounts for only 23 to 39 kilograms (51 to 86 pounds) of cadmium nitrate released. Records of dangerous waste discharges to the B Pond are poor prior to 1983, and information concerning chemical (non-radioactive) releases is sketchy prior to 1987 (DOE/RL 1993b). The last known, reportable discharge of chemical waste (sodium nitrate) occurred in 1987.

Most known radionuclide releases (except tritium) were associated with unplanned releases from the PUREX plant and B Plant. From 1963 to 1970, three of these releases to the B Pond occurred from operations at these facilities, discharging the estimated quantities of radionuclides, as follows (DOE/RL 1994):

- 1963-30 curies of cesium-137 and 0.05 curies of strontium-90 from B Plant

- 1964-2,500 curies of "mixed fission products" from PUREX Plant cooling water

- 1970-1,000 curies of strontium-90 from B Plant chemical sewer.

Tritium has been a perennial component of B Pond waste streams. An estimated 1,230 curies (decayed to 1988 levels) of tritium has been discharged during the operational life of the facility.

The discrepancies in reported inventories of these radionuclides may arise from decay status and methods of estimating quantities. Because results of waste stream sampling often produced results below minimum detectable activities (MDA) for these radionuclides, most of the inventories are reported as maximum quantities (i.e., less than the given quantity). In many cases, the MDAs were merely multiplied by liquid volumes to derive the inventories, so as not to underestimate inventories (DOE/RL 1993b).

\subsection{Results of Soil Contamination Characterization}

Because of the history of known and potential contaminants discharged to the B Pond, a series of evaluations of soil contamination was conducted for the main pond, expansion ponds, and nearby portions of the B-3-3 ditch. The first phases were completed from 1989 through 1992, and involved shallow soil sampling and analysis of sediments from the main pond, expansion ponds, and B-3-3 ditch (Kramer 1991), and deep vadose zone sampling in the expansion ponds (DOE/RL 1993b). A more recent vadose zone characterization effort was performed in 1999 in support of the $200-\mathrm{CW}-1$ operable unit (200-CW-1 OU) remedial investigation, which involved only the main pond and the B-3-3 ditch (Cearlock et al. 2000). The three expansion ponds are clean closed, and are no longer a part of the RCRA-regulated B Pond. However, salient results of sampling and analysis of these ponds are included here to help substantiate inferences about contamination from past practices at B Pond as a whole. 


\subsubsection{Early Phases of Soil Investigation: 1989-1992}

The first three phases of soil sampling involved extremely shallow soil sampling of the main and expansion ponds, with one deep vadose-zone boring in each of the three expansion ponds $(3 \mathrm{~A}, 3 \mathrm{~B}, 3 \mathrm{C}-$ see Figure 1.2). Additional soil samples were taken from locations around B Pond and contingency pond to provide local background values for comparison. The analytes sought during these projects included a comprehensive list of organic and inorganic constituents, metals, radionuclides, and radionuclide indicators (gross alpha, beta, and gamma scan). Analyses were selected based on known and suspected waste stream constituents (for list, see Kramer 1991).

Results of the first three phases indicated minimal amounts of contamination, either by radionuclides or hazardous constituents. In fact, Kramer (1991) notes that most metal concentrations were within "normal ranges," and implies that some elevated metals levels may have been the result of overlyaggressive acid digestion performed on samples, thus yielding higher levels of metals than are environmentally available. Significant results of these sampling efforts are as follow:

- Antimony, cadmium, copper, lead, mercury, and zinc were found above background levels, but were below toxic levels or Model Toxic Control Act (MCTA) (WAC 173-340) cleanup standards.

- Organic constituents were below detection or contractually-required quantitation limits, except for a few compounds at low levels associated with lab or blank contamination.

- Gross alpha was highest (42.59 pCi/g) in a sample from 31 meters (102 feet) beneath the 3A pond.

- Gross beta was highest $(718 \mathrm{pCi} / \mathrm{g})$ a sample in shallow soil from the $3 \mathrm{C}$ pond

- The highest strontium-90 result (36.1 pCi/g) was obtained from the 30-meter (97-foot) level in the borehole at the $3 \mathrm{~B}$ pond.

Based on these results the three expansion ponds were clean-closed in 1994 . The 3C pond is still maintained as a contingency diversion basin for the TEDF.

\subsubsection{Recent Investigations for 200-CW-1 OU: 1999}

During late 1999, test pits were excavated in the main pond and an adjoining part of the B-3-3 ditch. One deep borehole was drilled in the main pond where the B-3-3 ditch enters (Cearlock et al. 2000). The inlet location for the borehole was chosen because of its greater potential for retention of contamination within the vadose zone beneath the main pond. Both facilities have been covered with clean soil since 1994. Five trenches were excavated to a depth of 7.6 meters ( 25 feet) along the B-3-3 ditch, and six trenches and one deep borehole (drilled to basalt) were excavated in the main pond. Sampling was concentrated near the bottoms of the B-3-3 trench and main pond, with continuous samples taken from the bottoms to a level 3 meters ( 10 feet) below the bottoms. Thereafter, sampling intervals in the borehole were reduced to every 1.5 meters ( 5 feet) down to 7.6 meters ( 25 feet) below bottom, then to every 15 meters (50 feet) down to total depth. Additional samples were taken in the borehole at the interpreted 
level of the historically-highest water table and within the capillary fringe. The borehole was completed to the top of basalt (bottom of the aquifer) as a RCRA monitoring well.

Soil samples taken from the B-3-3 ditch and main pond were analyzed for volatile and semivolatile organic compounds, total metals, total petroleum hydrocarbons, anions, cyanide, ammonia as nitrogen, $\mathrm{pH}$, and radionuclides. Noteworthy results and maximum concentrations from the main pond are as follow:

- The greatest concentrations of hazardous constituents occur at the main pond bottom (1.5 to 4 meters [5 to 12 feet] below ground surface), with the highest in a trench in the northwest portion of the pond.

- Copper and zinc were found above background levels in places, but below MTCA B (WAC 173-340).

- Cadmium (max. $7.3 \mathrm{mg} / \mathrm{Kg}$ ), lead (max. $592 \mathrm{mg} / \mathrm{Kg}$ ), mercury $(11.9 \mathrm{mg} / \mathrm{Kg}$ ), and silver (max. $9.6 \mathrm{mg} / \mathrm{Kg}$ ) were above MTCA B cleanup levels in the northwest portion of the pond.

- Radionuclide activities were highest near the pond bottom, especially in the northwest portion of the pond, with the following maxima: strontium-90, $99.9 \mathrm{pCi} / \mathrm{g}$; cesium-137, 1,000 pCi/g; plutonium-239/240, $27.5 \mathrm{pCi} / \mathrm{g}$; and americium-241, $4.96 \mathrm{pCi} / \mathrm{g}$.

- Strontium-90 is found in increasing concentrations from the bottom of the pond to 8 meters ( 25 feet) below land surface, with traces as far down as 15 meters (50 feet) in the borehole.

Spectral gamma detection was used to survey the borehole to total depth. Cesium-137, which was the only manmade radionuclide detected in the borehole, produced a maximum activity of $21 \mathrm{pCi} / \mathrm{g}$ at 1.5 meters ( $\sim 5$ feet) below ground surface (corresponding to the approximate level of the pond bottom at this location). Total gamma activity was slightly elevated near the surface $(389 \mathrm{cpm})$, and near the bottom of the borehole on top of the Ringold lower mud unit $(280 \mathrm{cpm})$.

Contaminant distribution in the B-3-3 ditch was similar to the pattern in the main pond, such that most of the contamination was found at or slightly below the ditch bottom. However, concentrations were generally lower than those beneath the main pond. The most noteworthy contamination was from Aroclor-1260 (maximum $440 \mu \mathrm{g} / \mathrm{kg}$ ) and the semivolatile organic compound (SVOC) bis (2-ethylhexyl) phthalate (maximum $300 \mu \mathrm{g} / \mathrm{g}$ - a common lab contaminant). Five volatile organic compounds (VOCs) and 12 SVOCs were detected at low concentrations in the B-3-3 ditch sediments. Of these compounds, the highest concentration was that of bis (2-ethylhexyl) phthalate $(300 \mu \mathrm{g} / \mathrm{kg})$. Some of these VOCs and SVOCs were also detected in quality-control blanks, thus making some results suspect. Arsenic and mercury were found at maximum concentrations of $14.7 \mathrm{mg} / \mathrm{kg}$ and $0.51 \mathrm{mg} / \mathrm{kg}$, respectively. All results for hazardous constituents were below MTCA method B cleanup levels. No significant concentrations of 
man-made radionuclides were detected below 5 meters ( 15 feet) from ground surface. Maximum results for radionuclides obtained from the vadose zone at the B-3-3 ditch are as follow:

- Strontium-90, $9.79 \mathrm{pCi} / \mathrm{g}$

- Cesium-137, 188 pCi/g

- Plutonium-239/240, $5.73 \mathrm{pCi} / \mathrm{g}$

- Americium-241, $0.844 \mathrm{pCi} / \mathrm{g}$

- Plutonium-238, $0.50 \mathrm{pCi} / \mathrm{g}$.

In summation, contamination of soils in the 216-B-3 main pond and B-3-3 ditch appears to be relatively limited, both in depth and magnitude. The maximum levels of contamination were discovered at, or slightly below the former bottoms of these facilities. Strontium-90 is the only exception, being detected in minor concentrations as deep as 15 meters (50 feet) below land surface. 


\subsection{Hydrogeologic Summary}

Stratigraphy and groundwater hydrology of the B Pond have been described in several previous studies. The brief description given in this section is a summary of information derived from these earlier reports. The focus of this summary is the Hanford and Ringold Formations, because these strata comprise the uppermost aquifer and vadose zone in the area of the B Pond. The most detailed description of stratigraphic relationships at the B pond facility is presented in DOE/RL (1993a) and DOE/RL (1994). A description of groundwater hydrology and groundwater contamination in the region of the Hanford Site surrounding the B Pond is presented most recently by Hartman et al. (2000). A recent reinterpretation of well logs and hydrostratigraphy in the 200 East Area and vicinity by Williams et al. (2000) has allowed a more accurate portrayal of groundwater movement beneath the B Pond facility, upon which much of the groundwater monitoring program presented in Section 5.0 is based.

\subsection{Stratigraphy}

The principal geologic units beneath the B Pond include the Miocene/Pliocene Ringold Formation and the Pleistocene Hanford formation. As a tool for constructing a three-dimensional groundwater flow conceptual model, Thorne et al. (1994) describe and assign numbers to these strata that overlie the Columbia River Basalt on the Hanford Site. Williams et al. (2000) refine this nomenclature in the vicinity of the 200 East Area and the B Pond. A representative stratigraphic column based on these descriptions for the vicinity of the B Pond, is shown in Figure 2.1. The uppermost aquifer beneath the B Pond occurs primarily within sediments of the Ringold Formation, with the Hanford formation comprising the vadose zone. The Columbia River Basalt acts as the regional lower boundary for the uppermost unconfined aquifer.

Ringold Formation fluviolacustrine sediments consist of the unit A gravel (units 9A and 9C of Thorne et al. 1994, and Williams et al. 2000) and the lower mud unit (unit 8 of Thorne et al. 1994). The Ringold unit A gravel ranges in thickness from $\sim 12$ meters ( $\sim 40$ feet) in the area northwest of the main pond to $\sim 30$ meters $(\sim 100$ feet) in the southern portion. This unit is mainly composed of a silty sandy gravel with secondary lenses and interbeds of gravely sand, sand, and muddy sands to clay/silt (DOE/RL 1994). A particularly persistent lens of clay and silt within the Ringold unit A is designated unit 9B by Williams et al. (2000), and essentially separates the Ringold unit A into upper and lower components in the vicinity of the B Pond. The Ringold lower mud sequence is not present in the northwestern portion of the B Pond but is $\sim 24$ meters ( $\sim 80$ feet) thick near the southern extreme of the $3 \mathrm{C}$ expansion pond, and generally thickens south and southeast of the main pond. The lower mud unit consists mostly of various mixtures of silt and clay (DOE/RL 1994). This unit is particularly important to effluent infiltration and groundwater flow patterns near the B Pond (see Section 2.2).

The Hanford formation (unit 1 of Thorne et al. 1994) ranges in thickness from $\sim 40$ meters ( 130 feet) beneath the $3 \mathrm{C}$ expansion pond to $\sim 50$ meters ( $\sim 160$ feet) at the northwestern corner of the main pond (Davis et al. 1993). The Hanford formation is represented by three facies, in ascending stratigraphic order: 1) lower gravel sequence, 2) sandy sequence, and 3) upper gravel sequence (subdivisions after 


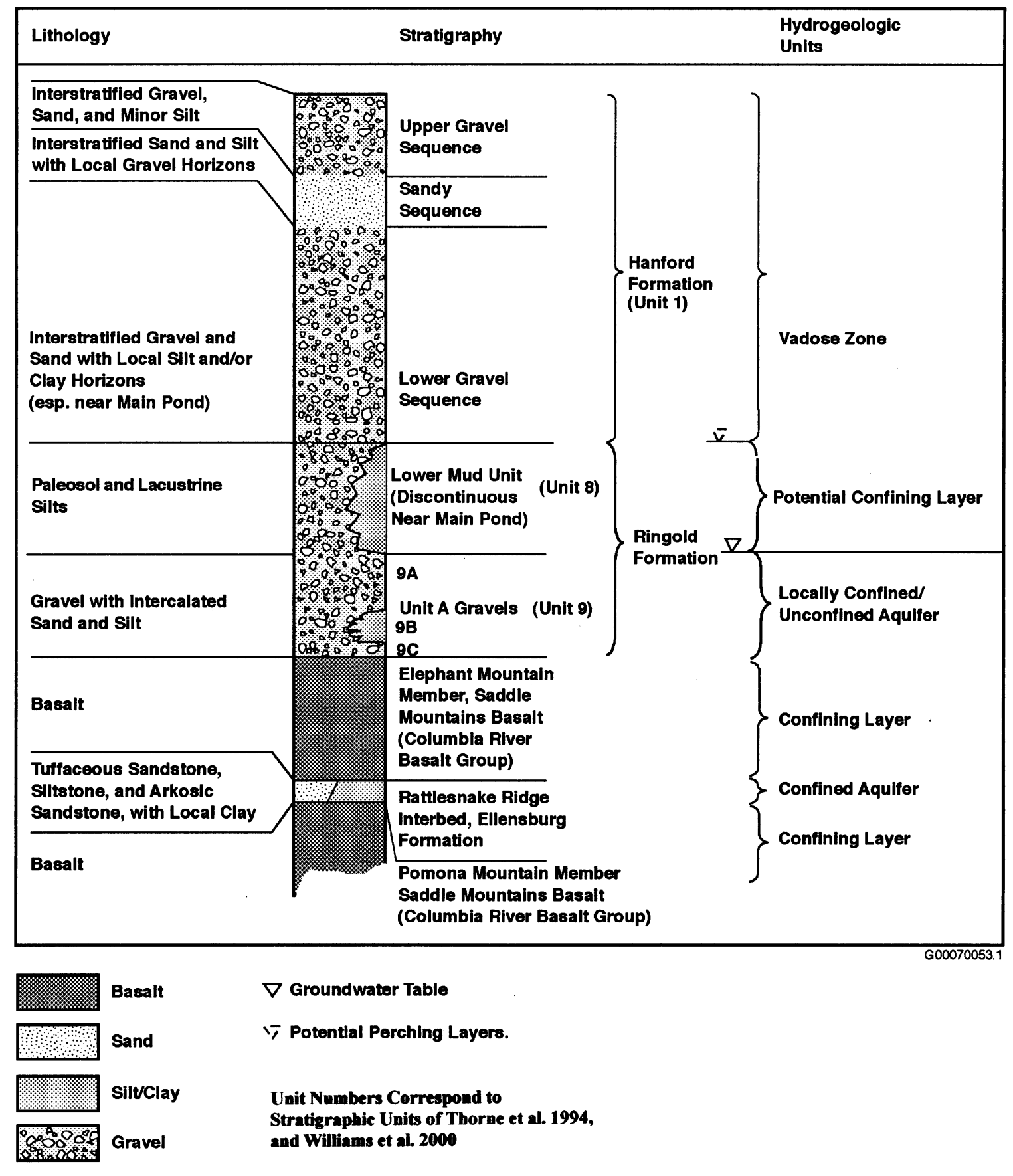

Figure 2.1. Generalized Stratigraphic Column for the B Pond Area 
Lindsey et al. 1992). The upper and lower gravel sequences are not differentiated in those areas where the intervening sandy sequence is absent. The gravel units consist of coarse-grained, basalt-rich, sandy gravels with varying amounts of silt/clay. These gravel units may also contain interbedded sand and or silt/clay lenses, and are notably rich in clay near the western portion of the main pond, as indicated in well logs from this area. The sandy sequence is dominated by sand to gravelly sand with minor sandy gravel or silt/clay interbeds. The sandy sequence is present mainly in the vicinity of the main pond of the B Pond, but has a significant silt/clay component in the extreme western portion of the main pond near the B-3-3 ditch.

\subsection{Groundwater Hydrology}

Lithologic and hydrologic data collected from drilling and groundwater monitoring over the past $10+$ years reveal that the uppermost aquifer beneath the B Pond occurs in a confined and unconfined state, depending on the specific location. These data suggest that the uppermost aquifer is unconfined to the west, southwest, and north of the main pond and becomes progressively more confined to the east and southeast of the facility. Figure 2.2 illustrates the hydrologic effects of the complex stratigraphy in the vicinity of B Pond. The heavy dashed line demarcates the approximate boundary between confined and unconfined conditions. Actual observations of water levels during drilling and monitoring, and aquifer testing data indicate that the change from unconfined to confined is apparently gradational in most of the areas around B Pond where the two aquifers meet. However, the high gradient, which is indicated by close packing of equipotentials near the western end of the main pond (Figure 2.3), suggests an impediment to flow in the Hanford formation where it abuts the transition area from Ringold Formation confined aquifer to the east. This may be resulting from the fine-grained component of the Hanford formation identified in this area. Figure 2.3 is a schematic cross section of the same general area depicted in Figure 2.2 along a northwest-southeast line. This figure also shows the emergent nature of units above the water table, the confining strata, and the effects associated with discharges from historical B Pond operations and current TEDF operation.

The Ringold unit A (9A) comprises the bulk of the uppermost aquifer in the B Pond area. In the extreme western portion of the facility (western end of the main pond and parts of the B-3-3 ditch) the aquifer occurs in the Hanford formation as well as the Ringold unit A. Although constraints to flow in the extreme western portions of the main pond area, indicated by a higher hydraulic gradient in this area, are probably a result of an isolated occurrence of fine-grained Hanford formation sediments, most of the

Hanford formation in the vicinity of the B Pond is coarse-grained and highly permeable. Estimates of the saturated thickness of the uppermost aquifer at the B Pond range from $<10$ meters ( $<33$ feet) in the northwest portion of the main pond to $>30$ meters ( $>98$ feet) near the southern end of the $3 \mathrm{C}$ expansion pond. Hydraulic conductivities in the B Pond area have been calculated at 1 to $640 \mathrm{~m} / \mathrm{d}$ ( 3 to 2,100 feet/d) depending on which unit (Ringold Formation and Hanford formation, respectively) this property is measured (WHC 1990b; Thorne et al. 1994).

The Ringold lower mud unit (unit 8 in Figure 2.2) forms both a confining horizon and potential perching layer for groundwater in the B pond area. An interpretation of the geometry of this stratum where it occurs in the vadose zone, is shown in Figure 2.2. The surface of the lower mud unit is also interpreted to dip gently to the south and southwest in the area immediately south of the main pond and 


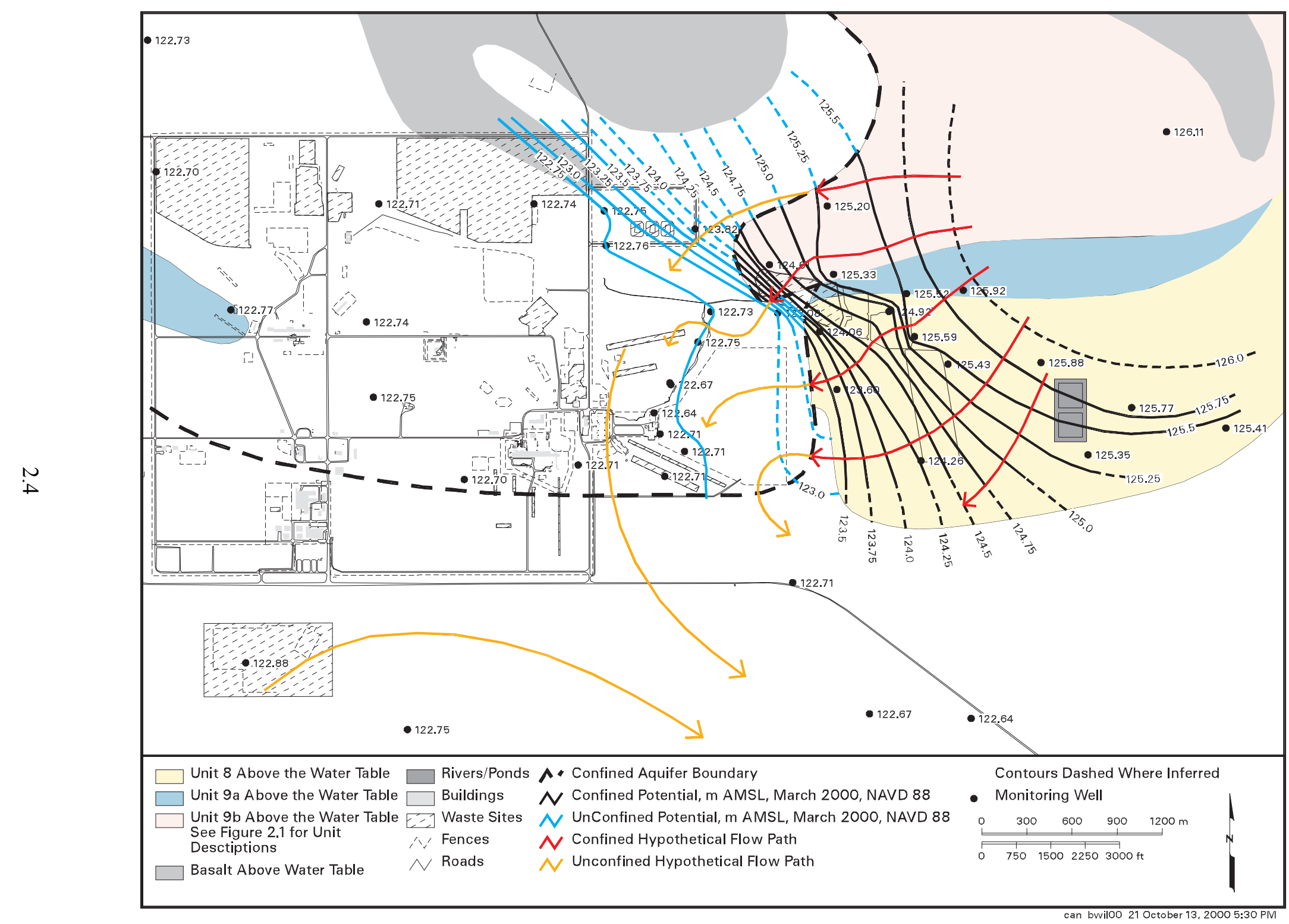

Figure 2.2. March 2000 Water-Table Map for the Confined and Unconfined Aquifers Near B Pond and Geometry of Significant Hydrostratigraphic Units (after Williams et al. 2000.) 


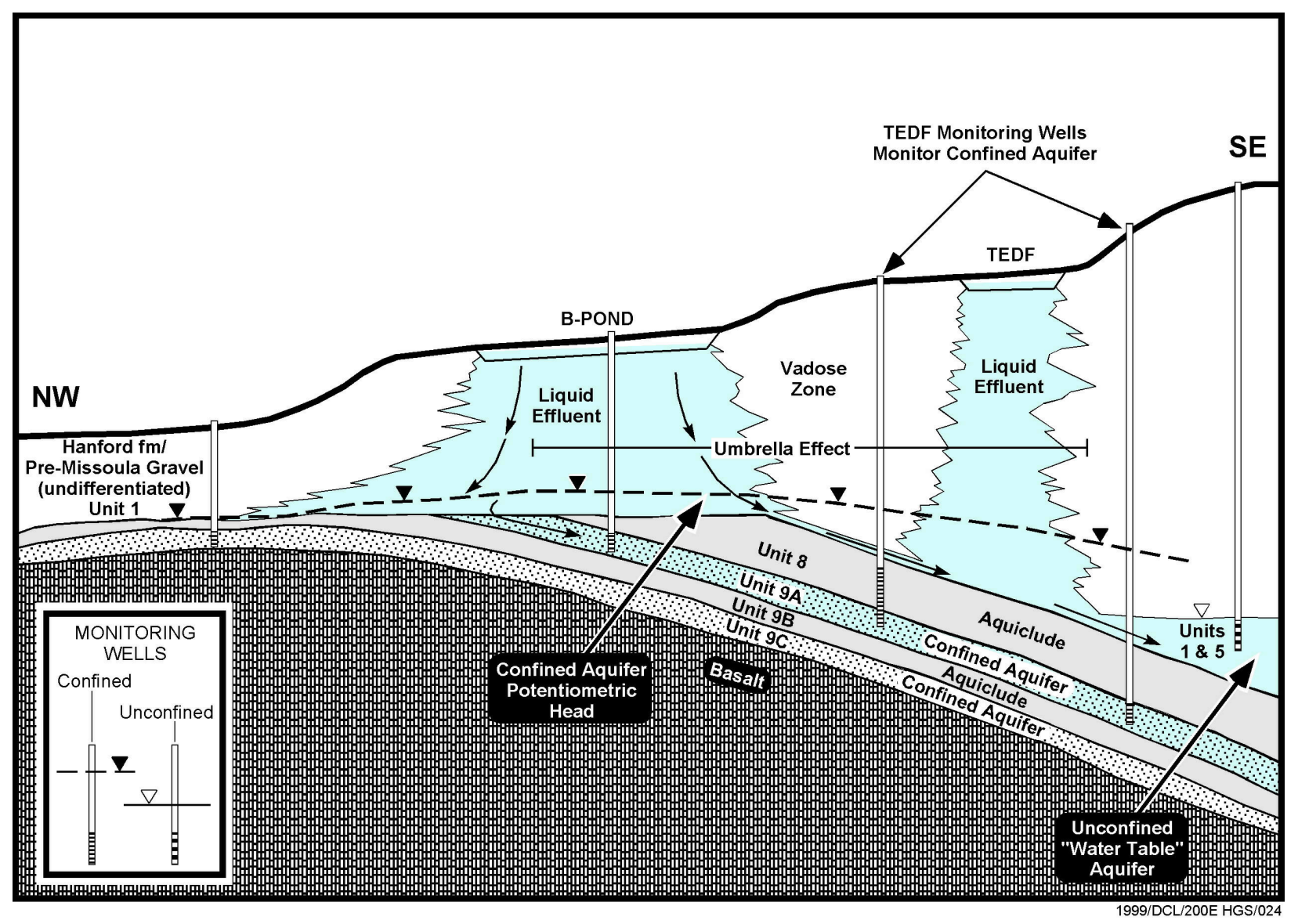

Figure 2.3. Schematic Cross-Section of the B Pond Area Showing General Hydrostratigraphic Relationships and the Effects of Historical Discharges by B Pond and TEDF. The "umbrella effect" refers to the interception and diversion of effluent by the relativelyimpermeable units 8 and 9B. The confined aquifer of unit 9A is locally unconfined beneath the B Pond. See text for discussion of flow potential. (After Williams et al. 2000.)

3C pond. Saturated hydraulic conductivity of this unit averaged $5.5 \mathrm{E}-07 \mathrm{~cm} \mathrm{sec}^{-1}(4.8 \mathrm{E}-04 \mathrm{~m} / \mathrm{d})($ Davis et al. 1993). The presence and configuration of this unit is probably responsible for the lack of correlatable hydraulic response in some monitoring wells in the uppermost aquifer near the $3 \mathrm{C}$ pond to large volumes of effluent diverted to this pond in 1994 (see Section 2.3). Because of its presence beneath the areas of effluent disposal to the ponds, the lower mud unit probably intercepted a large portion of infiltrating effluent during the years of operation. Farther east and southeast of the main pond, the lower mud unit also confines groundwater and isolates portions of the aquifer from surface contamination. From the configuration of units above the water table in Figures 2.2, it is apparent that much, if not most of the effluent infiltrating from the surface could have been diverted away from the underlying aquifer by the intervening fined-grained units 8 and 9B. This scenario is developed further in Section 4.0 to form a conceptual model for continued groundwater monitoring at the B Pond facility. 


\subsection{Groundwater Flow Interpretation}

Groundwater beneath the B Pond was historically interpreted to flow radially outward from a hydraulic mound, the apex of which was apparently located in the vicinity of the $3 \mathrm{~B}$ expansion pond. This mound was a result of past discharges to the B Pond, which ended in 1997. Continued well drilling, aquifer testing, and a recent reexamination of hydrostratigraphy by Williams et al. (2000) indicate that groundwater flow is more complicated than earlier interpretations suggested. Fine-grained units (units 8 and 9B of Figure 2.2) are assumed to have intercepted infiltrating effluent in some areas around the facility, diverting this water mostly to the south along the surface of the units - primarily the unit 8 lower mud unit. In the vicinity of the main pond these units are thin or absent, thus allowing effluent to reach units 9A and 9C. This artificial recharge has resulted in increased confined, hydrostatic pressure observed in wells completed below the fine-grained units east and southeast of the facility, some distance away from the point of infiltration. However, calculations of hydraulic conductivity, stratigraphic relationships recently recognized in distal southeast portions of the area (e.g., south of the TEDF-see Figure 1.2), and groundwater geochemistry (see Section 4.2) all suggest that actual movement of effluent in a southeast direction has been more limited than depicted by historical interpretations of the water table around B Pond (see Appendix B). Similar limitations to flow may exist immediately west of the main pond. Hence, the relatively-uniform radial flow pattern envisioned in earlier reports (e.g., Barnett and Teel 1997) was probably oversimplified and has been diminishing since RCRA monitoring began at B Pond.

Immediately west of the B Pond the uppermost aquifer is unconfined. The flow of groundwater is approximately from east to west in the vicinity of the pond. The flow pattern in the B Pond area has also changed significantly over the past few years because of the diminishing effects of the groundwater mound.

In general, Figure 2.2 illustrates that groundwater moves west to southwest within the Ringold confined aquifer beneath the B Pond complex before entering the unconfined aquifer south and west of the main pond. From that point, flow within the unconfined aquifer (Hanford formation) is also dominantly west-southwest before veering southeastward to flow over the top of the same units (e.g., unit 8) that are responsible for the confinement in the B Pond/TEDF region. This is possible because of the south-trending structural dip (exaggerated in Figure 2.3) of the Ringold Formation strata.

Based on March 2000 water-level measurements, the horizontal component of hydraulic gradient near B pond varies from $\sim 0.003$ east of the mound apex to 0.006 west-southwest of the former location of the main pond. The relationship:

$$
\overline{\mathrm{v}}=\mathrm{Ki} / \mathrm{n}_{\mathrm{e}}
$$

is used to estimate average linear flow velocities (v); where gradient values (i) are in the range noted above, hydraulic conductivity (K) ranges from $1 \mathrm{~m} / \mathrm{d}$ to $640 \mathrm{~m} / \mathrm{d}$ ( 3 to $2,100 \mathrm{ft} / \mathrm{d})$, and an effective porosity value $\left(\mathrm{n}_{\mathrm{e}}\right)$ of 0.25 is assumed. This calculation results in a range of average linear groundwater 
flow velocities of 0.01 to $15.36 \mathrm{~m} / \mathrm{d}(0.03$ to $50.07 \mathrm{ft} / \mathrm{d})$, with the lower rate occurring within the Ringold Formation unit A (9A and 9C) and the higher rate in the Hanford formation (unit 1).

Emphasis is placed on the fact that the water table and potentiometric surface represented in Figure 2.2 indicate flow potential. Although the hydraulic gradient around the B Pond clearly indicates a west to southwest groundwater flow direction, actual flow may be limited. The increased gradient indicated in the vicinity of the main pond suggests a constraint to flow in a west-southwest direction.

Four well pairs in the network, representing deep and shallow completions (see Table A.1, Appen$\operatorname{dix}$ A) are occasionally used to estimate the magnitude and direction of vertical hydraulic gradient. For the most recent measurements of water levels, all four pairs indicated a downward-directed component of hydraulic gradient, which is possibly a reflection of the continuing decline of the groundwater mound from remnant discharge effects. Head measurements from March 2000 indicated a downward-directed gradient of 0.03 and 0.04 in well pairs 699-42-42B/699-43-42J and 699-43-41E/699-43-41G, respectively. Because the screens in each of these wells are open to several meters of aquifer thickness, estimates of vertical head potential should be considered gross approximations.

\subsubsection{Status of the Groundwater Monitoring Network}

As the hydrographs of Appendix B illustrate, water levels in the 25 wells in the original network (see Figure 1.2) have generally declined during the life of the RCRA program, reflecting the curtailment, then ending of discharges to the facility. Exceptions to this trend occurred during the early to mid 1990s in some downgradient wells, such as wells 699-40-40A,B, 699-41-42, and wells around the TEDF. During the past $\sim 3$ years, however, water levels in all wells show a steep decline. The temporary reversal may have been the result of increased discharges in the late 1980s to early 1990s (see Figure 1.4). In most downgradient wells, water levels have dropped dramatically from 1996 to present. Most notably in this category are wells 699-40-40A, 699-42-39A, B, 699-42-40A, 699-42-42B, 699-43-40, 699-43-41E, G, 699-43-43, and 699-44-42. Some wells also indicate a very recent slowing in the high rate of water level decline since $\sim 1998$ (see below).

Table B.1 (Appendix B) summarizes the status of water levels in all wells formerly and currently in the B Pond network, and predicts the expected service life (in years) for these wells. The annual rates of decline are calculated using the most recent one year of data available for each well and assumes a linear rate of decline. For most wells, the one-year period ends in mid to late 1999. The years of potential service are calculated by subtracting the depth to water from the well depth, then dividing by the rate of decline. By this method, some wells are estimated to have only a few years of potential service remaining. Wells in the western portion of the network (e.g., well 699-44-42) generally have fewer years of service left than those elsewhere. Wells shared with the TEDF, southeast of the B Pond, appear to be least affected by the declining water levels. Wells 699-42-41, 699-43-40, 699-43-41F, 699-43-42J, 699-43-43, 699-44-42, and 699-44-43B are calculated to be dry or have pump intakes above the water level. Some wells may have service extended for a limited time by lowering of the pump in the well. In early 1998, the water level in well 699-43-45 had dropped to the point where the pump had to be lowered in the well to maintain serviceability. Well 699-42-41 was recently confirmed dry by field measurement. Discrepancies occur within Table B.1 because of errors in as-built diagrams, estimates in pump intake 
depths, and conflicting information on well completion. In most cases, these discrepancies have resulted in wells going dry slightly before or after predicted. In the most extreme case, conflicting records between depth and pump intake in well 699-43-41F result in an apparent pump level occurring deeper than the bottom of the well. However, for purposes of estimating serviceability this table is useful, particularly given the high rate of water level decline in most wells. As noted in the last column of Table B.1, most wells in the network indicate a recent slowing of rate of water level decline, as compared with the 1998 to 1999 period.

Projected life of wells at the Hanford Site was modeled by Wurstner and Freshley (1994) using the Coupled Fluid, Energy, and Solute Transport (CFEST) model. In the B Pond network, seven wells were predicted to be dry before the year 2000. Most of the wells projected to be dry are located near the main pond. By comparison, Table B.1 (Appendix B) estimates that 6 wells are now (year 2000) within $0.3 \mathrm{~m}$ of being dry. Five of these six wells (699-42-41, 699-43-40, 699-43-42J, 699-43-43, and 699-44-42) coincide with those predicted by Wurstner and Freshley (1994) to go dry during the same time frame. However, rates of water level decline have slowed appreciably in most wells in the network since $\sim 1998$. Only two wells, 699-41-35 (TEDF) and 699-43-45, have not displayed a slowing rate of decline. This recent change may help extend the life of some wells in the network.

No wells are completed above the Ringold lower mud unit (i.e., within the Hanford formation) in the B Pond network where this confining/perching unit is present. This region, from the lower mud unit to the surface, was initially within the unsaturated zone. However, it must be assumed that portions of B Pond discharges, including those diverted to the $3 \mathrm{C}$ pond, have been intercepted by the lower mud unit, particularly near the $3 \mathrm{C}$ pond and beneath the TEDF immediately to the east. 


\subsection{Summary of Groundwater Chemistry and Groundwater Quality Assessment}

Sampling and analysis of groundwater at the B Pond has been conducted under RCRA requirements since 1988. During this period, over 61,000 analytical results for various constituents were reported from groundwater samples from the B Pond well network. The majority of these results were below detection limits. This section summarizes the significant groundwater analytical results for the B Pond available through February 2000. Where available, the range for Hanford Site groundwater background concentrations of constituents are provided for comparison. These background values are taken from Johnson (1993) and DOE/RL (1997).

The B Pond was placed into assessment in 1990 because of elevated total organic halides (TOX) and total organic carbon (TOC) in two wells. From that time until mid 1996, comprehensive sampling and analysis was performed to determine the cause of these anomalies. In 1997, results spanning the first 8 years of monitoring were evaluated in Results of RCRA Groundwater Quality Assessment at the 216-B-3 Pond Facility (Barnett and Teel 1997). The assessment report concluded that these occurrences were mostly isolated, and, more significantly, that no hazardous waste could be correlated to TOC or TOX results. Both TOX and TOC were measured at relatively high concentrations primarily during a brief period in 1990 in a few wells at the B Pond, then subsequently only at concentrations near the limits of quantitation for these parameters. Only two organic compounds, which occurred in extremely low concentrations, were identified in the assessment as potential contributors to TOX and/or TOC concentrations. Also, recent evaluations of blank data for TOC indicate potential problems with reliability of results for this analyte when using certain methods (see Section 6.0).

Table 3.1 provides a summary of historical analytical results from groundwater sampling at the B Pond. The constituents chosen for this table are based on their significance as detected in groundwater analyses, or by elevated concentrations in soils (see Section 1.6). Contaminants consistently detected in groundwater that can be traced to B Pond operations are iodine-129 (maximum $5.33 \mathrm{pCi} / \mathrm{L}$ ), nitrate, and tritium. Only tritium has occurred in concentrations above drinking water standard (DWS). Concentrations of both nitrate and tritium have generally trended downward since monitoring began at the facility.

\subsection{Radionuclides and Nitrate}

With the exception of tritium, radionuclide activities in groundwater have been very low at the B Pond, particularly in light of supposed waste streams. Figure 3.1 illustrates the trends of tritium (maximum $232,000 \mathrm{pCi} / \mathrm{L}$ ) and nitrate (maximum 22,500 $\mu \mathrm{g} / \mathrm{L}$ ) in wells with significant trends, including the well (699-41-40) with the historically highest concentration of both of these constituents. Tritium and nitrate are sampled in selected wells at the B Pond as part of the sitewide surveillance monitoring (Atomic Energy Act). Trends for nitrate concentration are unchanged or downward for most wells in the network, but a few show recent upward trends for this constituent. Most wells in the network produce nitrate results below, to slightly above Hanford Site background (5,681 to $12,400 \mu \mathrm{g} / \mathrm{L})$, and all results have been well below DWS. 
Table 3.1. Summary of Groundwater Results for Constituents of Potential Significance at the B Pond

\begin{tabular}{|c|c|c|c|}
\hline Constituent & $\begin{array}{l}\text { Maximum } \\
\text { Result(s) }\end{array}$ & Well(s)/Date(s) & Overall Trends/Comments \\
\hline Arsenic (total) & $\begin{array}{l}18 \mu \mathrm{g} / \mathrm{L} \\
12 \mu \mathrm{g} / \mathrm{L}\end{array}$ & $\begin{array}{l}699-44-42 / 6-92 \\
699-43-45 / 10-93 \\
\end{array}$ & $\begin{array}{l}\text { None/most results within background } \\
\text { range }^{(\text {a) }}\end{array}$ \\
\hline Cadmium $^{(b)}$ (total) & $3.0 \mu \mathrm{g} / \mathrm{L}$ & $699-42-42 B / 7-93$ & None/most results non-detect \\
\hline Copper $^{(b)}$ (total) & $37 \mu \mathrm{g} / \mathrm{L}$ & 699-40-39/10-93 & None \\
\hline Lead $^{(\mathrm{b})}$ (total) & $\begin{array}{l}14 \mu \mathrm{g} / \mathrm{L} \\
11 \mu \mathrm{g} / \mathrm{L}\end{array}$ & $\begin{array}{l}699-43-41 \mathrm{E} / 6-91 \\
699-43-42 \mathrm{~J} / 7-91\end{array}$ & $\begin{array}{l}\text { None/most results non-detect or } \\
\text { background range }{ }^{(\mathrm{a})}\end{array}$ \\
\hline Mercury $^{(b)}$ (total) & $\begin{array}{ll}---- \\
---1\end{array}$ & ---- & $\begin{array}{l}\text { No detections. No analyses since } \\
1994\end{array}$ \\
\hline Nitrate & $\begin{array}{l}22,500 \mu \mathrm{g} / \mathrm{L} \\
17,000 \mu \mathrm{g} / \mathrm{L}\end{array}$ & $\begin{array}{l}699-41-40 / 12-89 \\
699-42-39 \mathrm{~B}\end{array}$ & $\begin{array}{l}\text { Possible upward trend in some } \\
\text { wells-down in most wells } \\
\text { (Figure 3.1) }\end{array}$ \\
\hline Silver $^{(\mathrm{b})}$ (total) & $9.5 \mu \mathrm{g} / \mathrm{L}^{*}$ & 699-42-40A/7-93 & $\begin{array}{l}\text { None/only } 5 \text { detections entire history } \\
\text { of network }\end{array}$ \\
\hline Cesium- $137^{(\mathrm{b})}$ & $5.38 \mathrm{pCi} / \mathrm{L}$ & 699-43-42J/10-93 & $\begin{array}{l}\text { None-this result is the only } \\
\text { detection; only one analysis exists per } \\
\text { well-gross beta substituted }\end{array}$ \\
\hline Strontium- $90^{(\mathrm{b})}$ & ----- & ----- & $\begin{array}{l}\text { No analyses historically for this } \\
\text { constituent; gross beta substituted }\end{array}$ \\
\hline Iodine-129 & $\begin{array}{l}5.33 \mathrm{pCi} / \mathrm{L} \\
4.36 \mathrm{pCi} / \mathrm{L}\end{array}$ & $\begin{array}{l}699-42-42 \mathrm{~B} / 3-98 \\
699-43-43 / 4-98\end{array}$ & $\begin{array}{l}\text { Possible upward trends in these two } \\
\text { wells }\end{array}$ \\
\hline Gross alpha & $\begin{array}{l}7.58 \mathrm{pCi} / \mathrm{L}^{*} \\
5.82 \mathrm{pCi} / \mathrm{L}\end{array}$ & $\begin{array}{l}699-40-40 \mathrm{~B} / 1-94 \\
699-42-39 \mathrm{~A} / 4-92 \\
\end{array}$ & $\begin{array}{l}\text { None/most results within background } \\
\text { range }^{(\text {a) }} \text { (Figure 3.2) }\end{array}$ \\
\hline Gross beta & $\begin{array}{l}20 \mathrm{pCi} / \mathrm{L}^{*} \\
16.3 \mathrm{pCi} / \mathrm{L}^{*} \\
6.95 \mathrm{pCi} / \mathrm{L}\end{array}$ & $\begin{array}{l}699-40-40 \mathrm{~A} / 1-97 \\
699-42-42 \mathrm{~B} / 1-97 \\
699-42-39 \mathrm{~A} / 1-94 \\
\end{array}$ & $\begin{array}{l}\text { Possible upward trends in two } \\
\text { wells - most results within } \\
\text { background range }{ }^{\text {(a) }}\end{array}$ \\
\hline Tritium & $226,000 \mathrm{pCi} / \mathrm{L}$ & $699-41-40 / 4-90$ & $\begin{array}{l}\text { Decreasing concentrations in all wells } \\
\text { since groundwater monitoring began } \\
\text { (Figure 3.1) }\end{array}$ \\
\hline Total Organic Carbon & $\begin{array}{l}29,000 \mu \mathrm{g} / \mathrm{L}^{(\mathrm{c}, \mathrm{d})} \\
6,000 \mu \mathrm{g} / \mathrm{L}^{* \mathrm{~d}} \\
2,000 \mu \mathrm{g} / \mathrm{L}^{(\mathrm{d})}\end{array}$ & \begin{tabular}{|l|}
$699-43-44 / 9-99$ \\
$699-40-40 \mathrm{~A} / 4-93$ \\
$699-42-41 \&$ \\
$699-42-39 / 4-92$ \\
\end{tabular} & $\begin{array}{l}\text { None-most results below limits of } \\
\text { quantitation (see discussion } \\
\text { Section 3.3) }\end{array}$ \\
\hline Total Organic Halides & $\begin{array}{l}1,310 \mu \mathrm{g} / \mathrm{L}^{(\mathrm{d})} \\
1,260 \mu \mathrm{g} / \mathrm{L}^{(\mathrm{d})}\end{array}$ & $\begin{array}{l}699-43-41 \mathrm{~F} / 4-90 \\
699-43-41 \mathrm{E} / 5-90\end{array}$ & $\begin{array}{l}\text { Possible decreasing concentrations in } \\
\text { some wells since 1990. Most results } \\
\text { below limits of quantitation (see } \\
\text { discussion Section 3.3) }\end{array}$ \\
\hline \multicolumn{4}{|c|}{$\begin{array}{l}\text { * Suspect result or outlier. } \\
\text { (a) Background range is based on Hanford Site background values provided by Johnson (1993) and DOE/RL } \\
\text { (1997). } \\
\text { (b) Significance is based on soil concentrations (see Section 1.6); (all others based on historical groundwater } \\
\text { results). } \\
\text { (c) Samples taken during drilling operations; results are interpreted to be unrelated to groundwater quality. } \\
\text { (d) Single result, not replicate average. }\end{array}$} \\
\hline
\end{tabular}




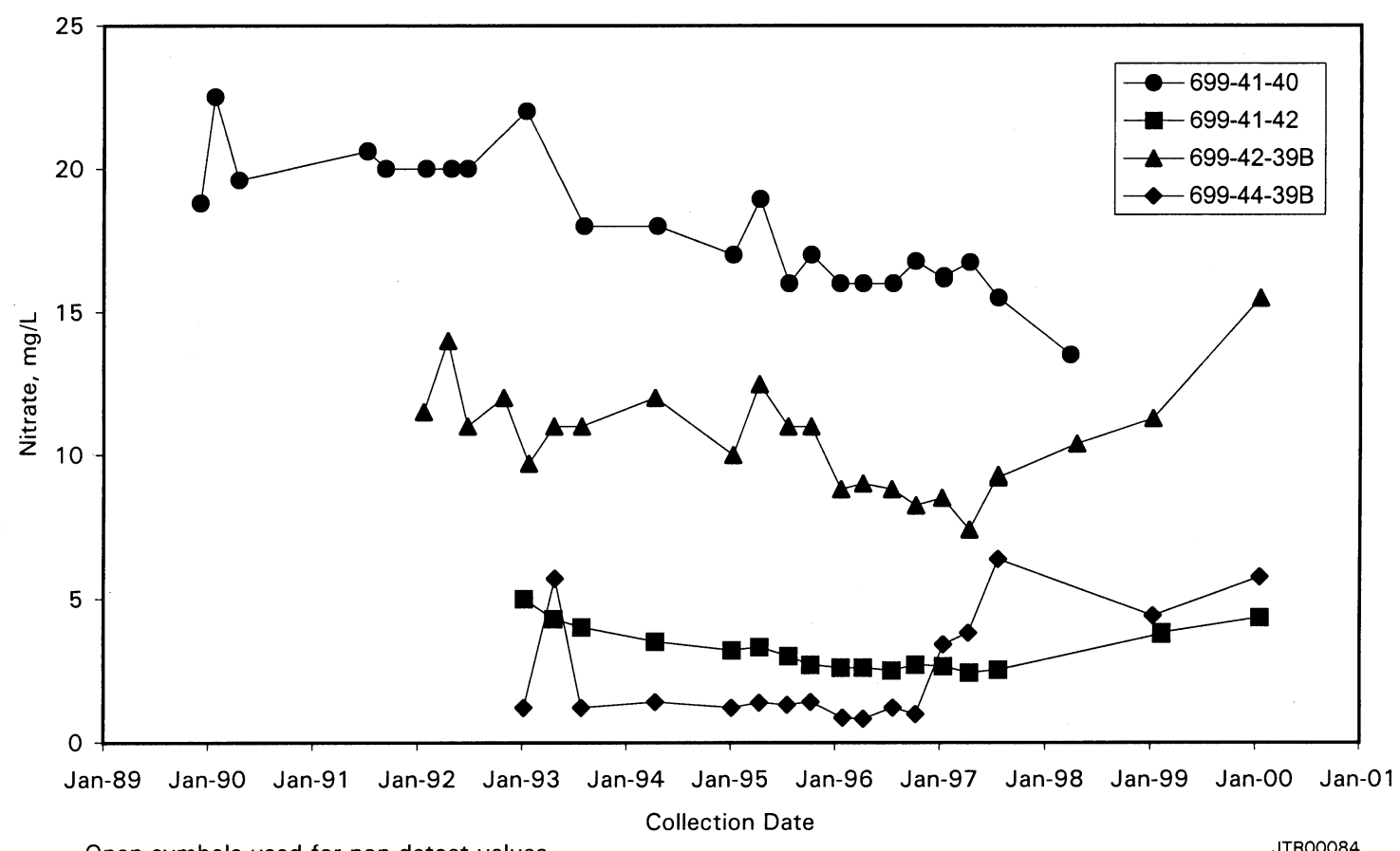

Open symbols used for non-detect values

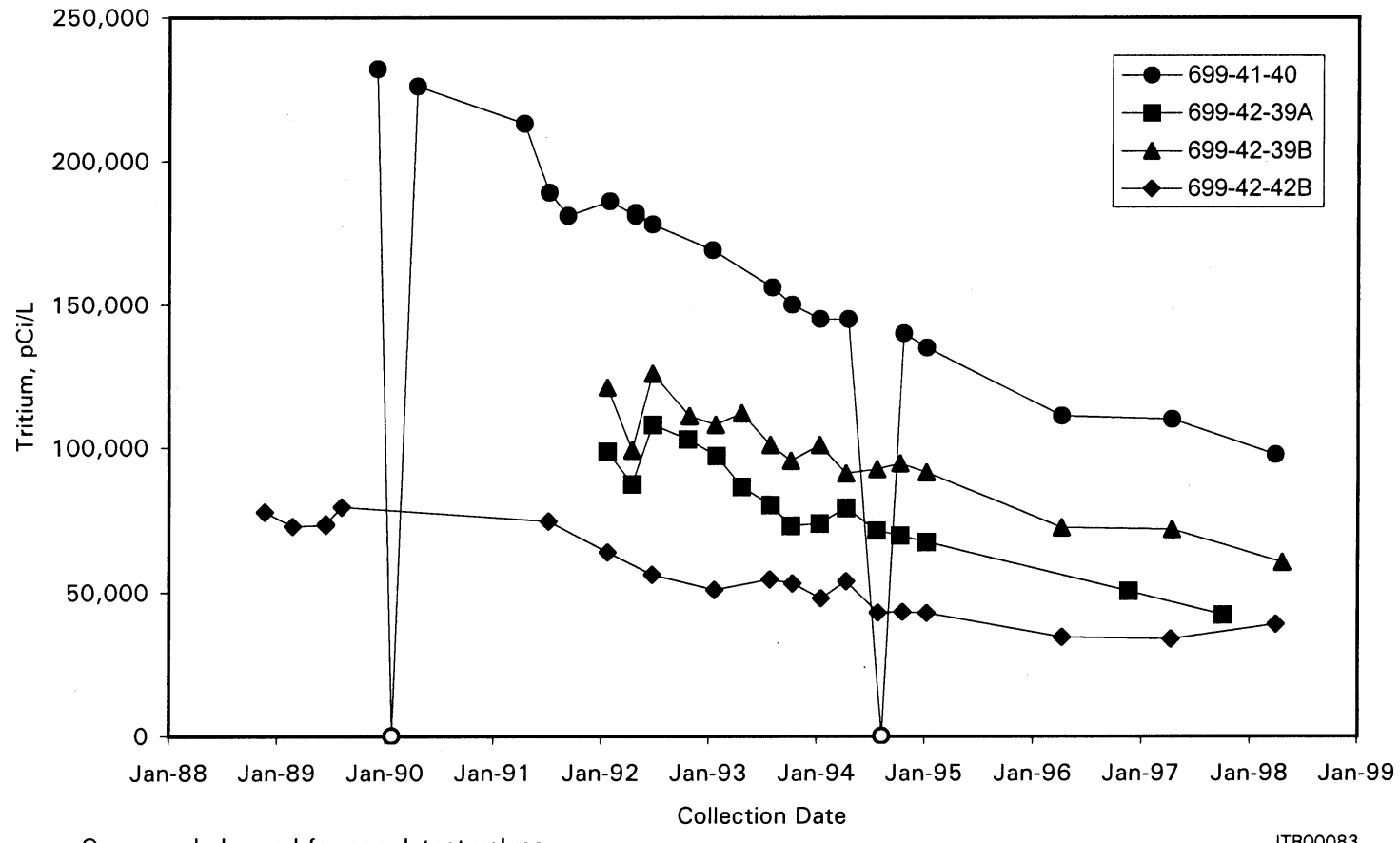

Open symbols used for non-detect values

JTR00083

Figure 3.1. Plots for Tritium and Nitrate at the B Pond Facility in Wells Illustrating Significant Trends. Records end in 1998 for tritium because wells at the B Pond are sampled for tritium on a triennial schedule by a sitewide surveillance monitoring. 
Of eight wells in the B Pond network sampled for iodine-129, this radionuclide was detected at least once in each well. Wells in the western portion of the facility appear to produce the highest results for iodine-129, with wells 699-42-42B and 699-43-43 consistently producing results above detection, and apparently displaying rising trends in activities. The most recent sample taken in well 699-42-42B, in March 1998, also produced the highest result (5.33 pCi/L) from the network thus far. Like tritium, iodine-129 is not sampled as part of RCRA groundwater monitoring, but wells in the B Pond network are routinely sampled for this constituent by the Hanford sitewide groundwater surveillance monitoring.

Strontium-90 is listed in Table 3.1 as a potentially significant constituent in groundwater because of its abundance in soil at the B Pond (see Section 1.6). Although no analyses have been performed for this specific radionuclide in groundwater, most gross beta (an effective indicator for strontium-90) results at B Pond have been near Hanford Site background levels (see Table 3.1).

Cesium-137 is also listed as a potential contaminant because of slightly elevated levels of this isotope in soil analytical results. Only one groundwater analysis per well (all during 1993) has been performed for each well in the network. Of these, only well 699-43-42J produced a detectable result $(5.38 \mathrm{pCi} / \mathrm{L})$. As with strontium-90, gross beta analysis is used to screen for cesium-137.

Trends for gross alpha and gross beta activities for B Pond wells are illustrated in Figure 3.2. Both of these indicators have been mostly within or below calculated Hanford Site background (Johnson 1993, $\mathrm{DOE} / \mathrm{RL}$ 1997). These studies indicate a range in groundwater for gross alpha background activity of 0.962 to $5.79 \mathrm{pCi} / \mathrm{L}$, and the range for gross beta is 5.88 to $12.62 \mathrm{pCi} / \mathrm{L}$. Discharges to the B Pond of Columbia River water, which is naturally lower in gross alpha and gross beta activities, has probably diluted groundwater beneath the facility. The simultaneous spikes evident in gross beta in January 1997 are probable errors in analysis, since it is unlikely that such excursions in concentrations would occur at the same time in wells widely separated in location.

\subsection{Metals}

Chromium, iron, and manganese have historically exceeded DWS in several wells at the B Pond facility. Elevated concentrations of these metals are found in many wells on the Hanford Site, and have been attributed to well construction, and do not have significance as groundwater or soil contaminants at the B Pond. Arsenic has been detected at extremely low levels (far below DWS) in wells near the west end of the main pond. There is a possibility that arsenic in groundwater at the B Pond originated from cribs and ditches in the 200 East Area, just prior to the onset of significant hydraulic mounding at the B Pond, or that a very minimal amount was discharged to the main pond via the ditches (Johnson et al. 1995). The maximum concentration of arsenic (18 $\mu \mathrm{g} / \mathrm{L})$ was measured in well 699-44-42 in June 1992.

Cadmium, copper, lead, mercury, and silver are listed as potentially significant constituents in Table 3.1 because of elevated levels of these metals detected in some soil samples during recent investigations (Section 1.6). Out of hundreds of groundwater analyses for each of these constituents in the B Pond well network, most are below detection or within background ranges. All results for these metals have been below maximum contaminant levels and DWS. Mercury analyses have not been performed since 1994. 

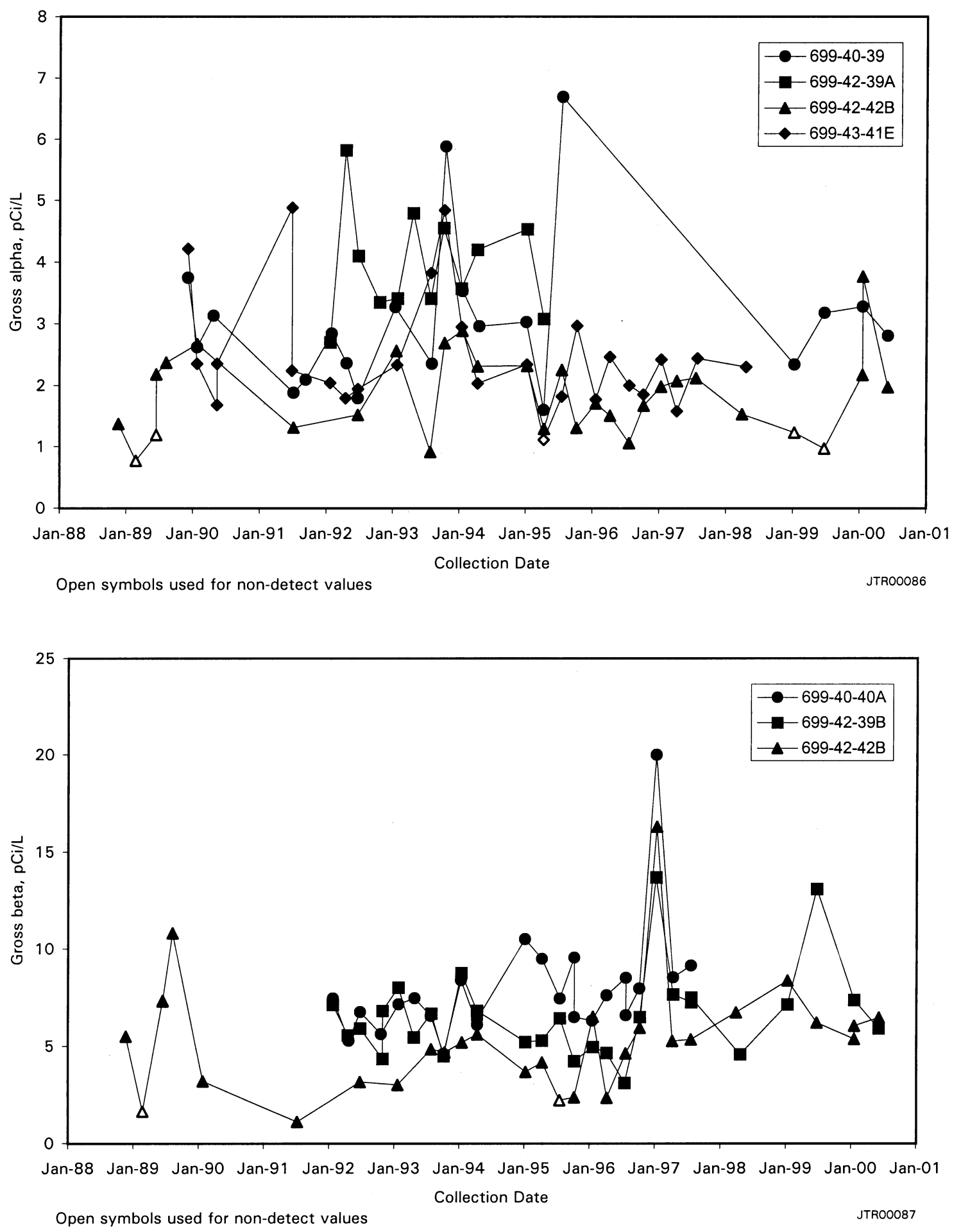

Figure 3.2. Trend Plots for Gross Alpha and Gross Beta in Selected B Pond Wells 
Specific conductance (electrical conductivity) measurements in all B Pond wells have routinely produced results consistently below or within the range of Hanford Site background values for groundwater (314 to $530 \mu \mathrm{mhos} / \mathrm{cm}$ ). Additionally, the spatial variation for specific conductance is high within the B Pond network, with averages ranging from $170 \mu \mathrm{S} / \mathrm{cm}$ in well $699-42-40 \mathrm{~A}$ to $370 \mu \mathrm{S} / \mathrm{cm}$ in well 699-44-43B. Of the wells in the network sampled since 1999, all indicate a recent trend of rising specific conductance. Rising specific conductance in some wells has been occurring since late 1995 (Figure 3.3). The lowest specific conductance results occur in wells immediately north to northwest of the 3C pond and south of the main pond (Figure 3.4). Two of these wells, 699-42-41 and 699-42-40A are near the point of most recent discharges to the $3 \mathrm{C}$ pond. Most of the effluent sent to the facility, especially in the later days of operation, was water originating from the Columbia River ("raw water"), which has very low dissolved solids load and low specific conductance. This effluent significantly diluted groundwater beneath B Pond and resulted in specific conductance levels lower than natural background for the aquifer. Now that the source of water has been discontinued, specific conductance values are beginning to resume natural profiles. The last discharges of this nature were sent to the 3C expansion pond from 1994 to 1997.

Analyses for such compounds as ammonium and hydrazine were conducted in the early years (ca. 1989-1994) of groundwater sampling at B Pond because of their presence in waste streams, but yielded only sporadic, marginally detectable results. Hydrazine, a highly reactive reducing agent, was detected in only four analyses, three of which are of suspect quality. Both of these compounds are short-lived in the oxidizing environment typified by B Pond discharge.

\subsection{Total Organic Carbon and Total Organic Halides}

Although TOC and TOX were responsible for placing the B Pond into assessment status in 1990, these indicators have since been extremely low in concentration. Most results for both have been below the limits of quantitation. Attempts to tie these indicators to specific contaminants were unsuccessful, primarily because of the lack of correlation of TOC and TOX with results of other compounds (Barnett and Teel 1997). Only one compound, tris (2-chloroethyl) phosphate $\left(\left[\mathrm{ClC}_{2} \mathrm{H}_{4}\right]_{3} \mathrm{PO}\right)$, a plasticizer, was detected sporadically during the six years of assessment, but was not consistent with corresponding occurrences of low-level TOX or TOC results. Moreover, no waste stream components were identified that could account for elevated TOX or TOC in groundwater. Well construction materials were tentatively identified as a possible source of tris (2-chloroethyl) phosphate. All replicate averages for both TOC and TOX have been below quantitation limits since the 1997 assessment. 


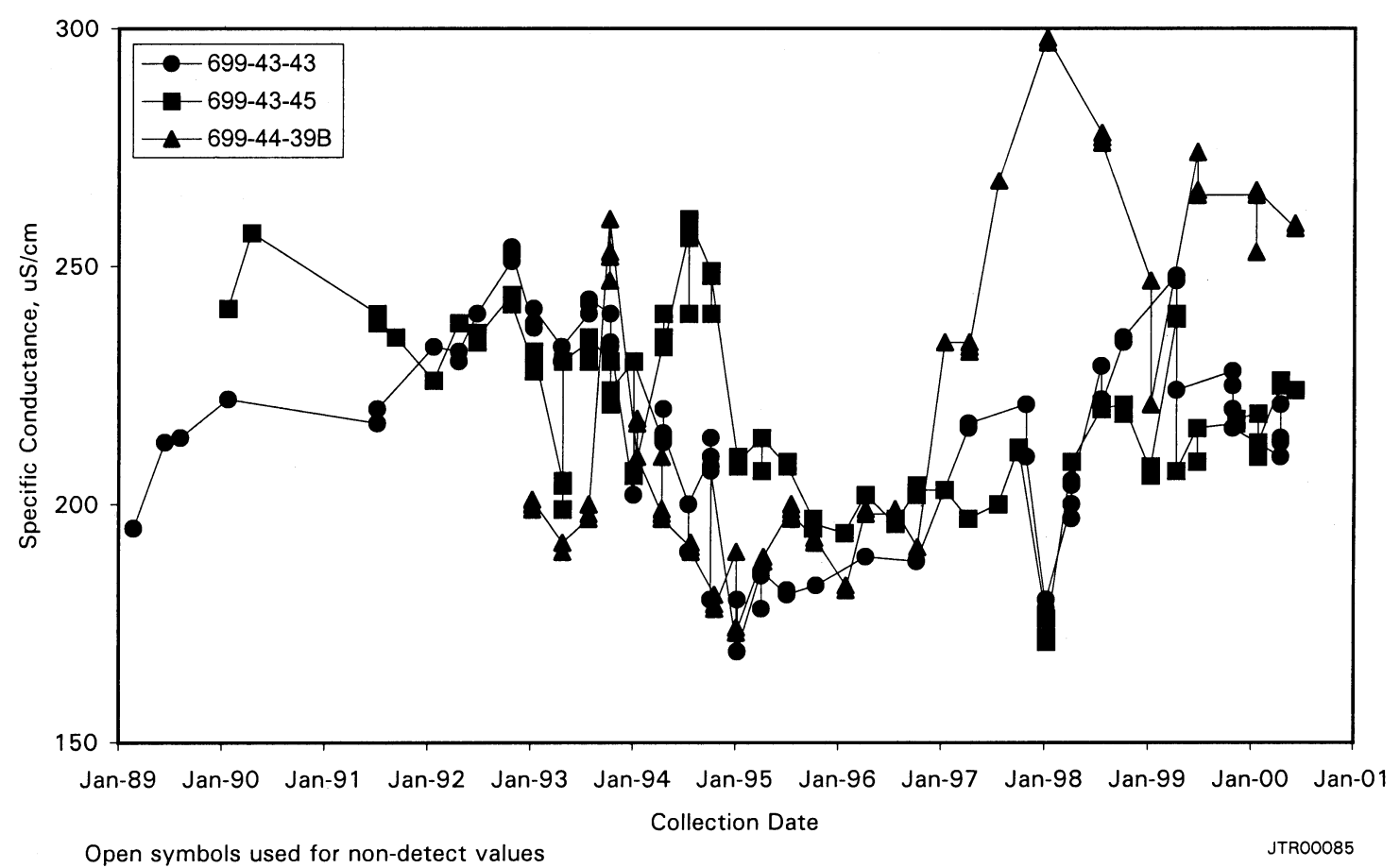

Figure 3.3. Representative Trends for Specific Conductance at B Pond 


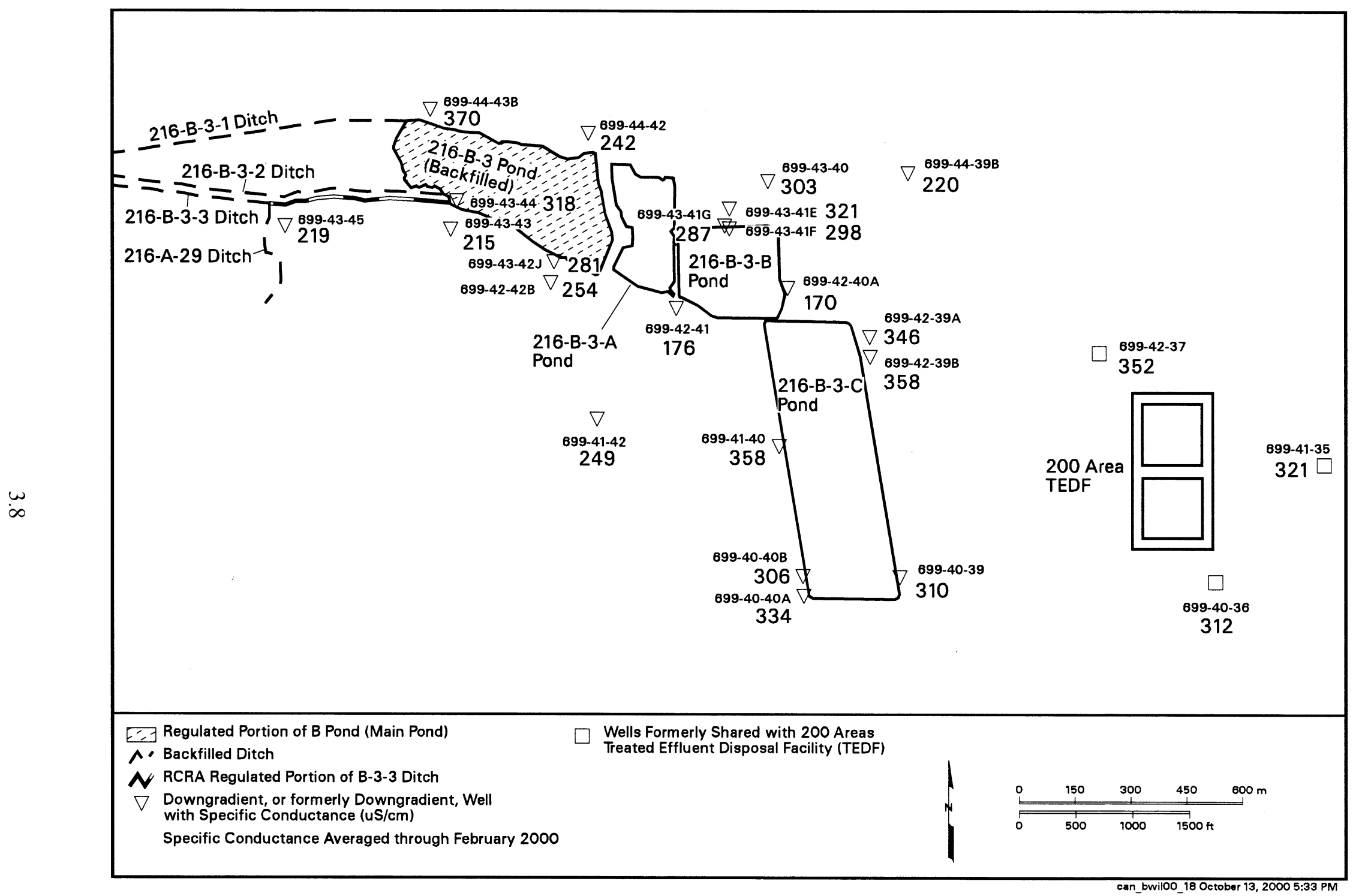

Figure 3.4. Map of the B Pond Area Showing Long-Term Average Values for Specific Conductance (large numbers are $\mu \mathrm{S} / \mathrm{cm}$ ) 


\subsection{Conceptual Model}

Chemical and radiological analyses of soil and exhaustive groundwater analyses have not revealed any substantial contamination in these media by hazardous or radiogenic wastes. As described in Section 1.6, extensive sampling of soils in the vadose zone across the B Pond showed very little contamination. From characterization and monitoring performed thus far, it would appear risks to groundwater from the B Pond soils and actual impacts are minor. Recent work on hydrostratigraphy of the B Pond area has provided further insight into the potential for contamination occurrence and movement in groundwater. A conceptual model of contaminant transport is proposed here to guide future groundwater monitoring. Because of the dynamic conditions at the B Pond (a receding groundwater mound and consequent alteration of groundwater flow patterns), this model will require periodic updates.

\subsection{Hydrogeology Component}

Aquifer tests from B Pond wells near the south end of the $3 \mathrm{C}$ expansion pond and wells monitored for the TEDF indicate low hydraulic conductivities and low groundwater flow rates $(\leq 0.004 \mathrm{~m} / \mathrm{d}[\leq 0.013 \mathrm{ft} / \mathrm{d}])$ in the Ringold Formation unit A (9A) in this area. Recent hydrostratigraphic research by Williams et al. (2000) indicates that a stratigraphic "trap" could exist near the south and southeast extremities of the facility (e.g., south of the TEDF and the $3 \mathrm{C}$ pond) that may have prevented any appreciable groundwater movement in this direction. Additionally, the aquifer in this region appears to be isolated from effluent discharges from a significant part of the B Pond operations, and probably all of the TEDF operations. The effluent is mostly being intercepted by the intervening lower mud unit (unit 8) and diverted predominantly south along the upper surface of this fine-grained unit. Some of this effluent will eventually reach the erosional edge of the lower mud unit and enter the more permeable Hanford formation south and west of the main pond (see Figures 2.2 and 2.3). Figure 4.1 shows a schematic representation of postulated hydrostratigraphic relationships in the B Pond/TEDF area. This interpretation is supported by the fact that no hydrologic response to TEDF discharges has been thus far observed in the TEDF wells (completed in unit 9A of the Ringold Formation) since the facility began operating in 1995. Wells in this region, including those near the southern extreme of the 3C Pond have shown only a general decline in head since installation in the early 1990 s, with only a brief period of stasis in 1995, prior to TEDF operation.

\subsection{Groundwater Chemistry Component}

Comparisons of tritium results in four well clusters, containing two or more wells at the same location, and which monitor different portions of the uppermost aquifer, suggest vertical discrimination of concentrations of constituents. With the exception of one group, deeper wells in the groups have produced historically higher concentrations of tritium. This trend is reversed in wells 699-43-41E,F, G, with the shallow well having higher concentrations. Concentrations of other constituents, such as iron, nitrate, manganese, $\mathrm{pH}$, and conductivity, display differences between deep/shallow well pairs, but no consistent pattern is recognizable across all four clusters of wells. No obvious differences between shallow/deep well companions were observed for concentrations of total organic carbon or total organic halides. Reasons for vertical differences in concentrations of constituents are undetermined, but may be due to an 
Northwest

Southeast

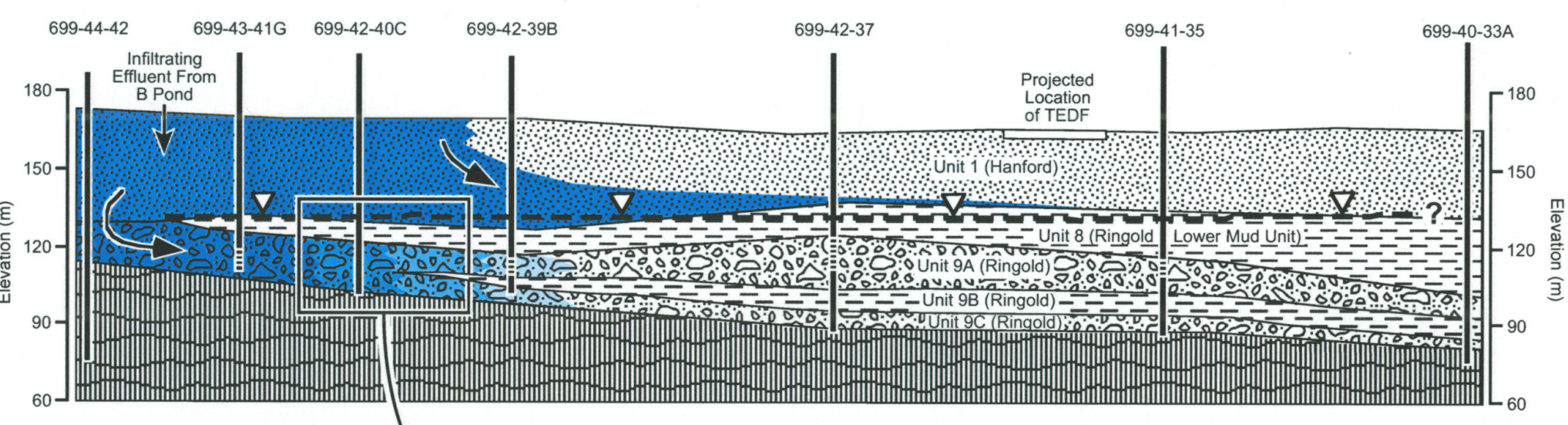

Variable penetration of

effluent into formation

(darker $=$ greater penetration)

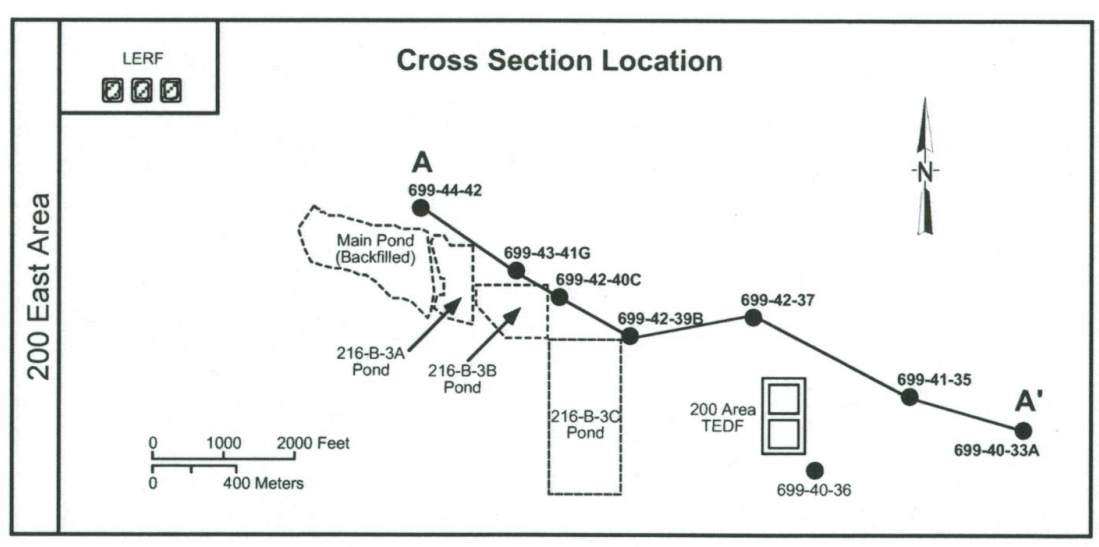

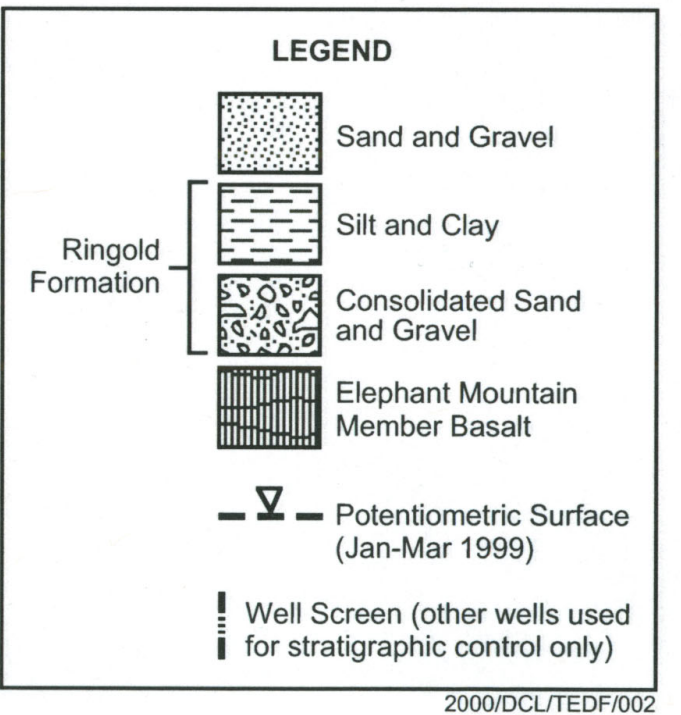

Figure 4.1. Hypothetical Hydrostratigraphic Relationships and Effluent Flow Patterns in the Vicinity of B Pond 
interplay of factors such as well construction, aquifer heterogeneities, variables in transport characteristics, and varying concentrations of constituents in effluent. In the case of tritium, later discharges of effluent were lower in tritium concentrations than earlier discharges, thus possibly accounting for higher concentrations being observed mostly lower in the aquifer.

Tritium distribution in groundwater at the B Pond is depicted by the map of maximum results in Figure 4.2. The most striking feature of this illustration is the apparent southwest-northeast line demarcating the limit of tritium occurrence in the aquifer. This feature suggests that tritium, and presumably, effluent from the B Pond may not have migrated southeast of this line. In fact, low level analyses for tritium from wells at the TEDF indicate levels of tritium below natural background for the uppermost aquifer (Barnett 1998), thus suggesting a relatively old age for groundwater at this location. Analyses for tritium in these wells have been performed since 1992 or earlier. This feature has important implications for groundwater monitoring at the B Pond (see Section 4.0).

Major ion chemistry for confined-aquifer groundwater in the vicinity of the B Pond also supports a southwest-northeast demarcation between groundwater chemistry (Figure 4.3). Wells east of the 3C pond are dominated by sodium bicarbonate groundwater, suggesting a more evolved groundwater chemistry and greater age, whereas wells closer to the main pond and $3 \mathrm{~A}$ and $3 \mathrm{~B}$ expansion ponds, and the northern wells around the 3C pond show either a less evolved (e.g., less sodium and more calcium) or dilute chemistry. The low ionic strength of groundwater from well 699-42-40A most closely resembles the ionic character of the effluent sent to the 3C pond until 1997 (thereafter diverted to the TEDF). This condition lends to tritium-related evidence, which indicates that wells east to southeast of the B Pond are unaffected by discharges from the facility. Had effluent reached these areas southeast of B Pond, the water chemistry would more closely resemble that of wells around the main pond and northern portion of the $3 \mathrm{C}$ expansion pond.

Considering all of the findings of media analyses (Sections 1.6 and 3.0), the most useful indicators for radionuclide detection will be gross alpha and gross beta analysis. These parameters will have the greatest potential for alerting to the presence of the radionuclides species thought to be potentially present in the vadose zone beneath the main pond. Arsenic, iodine-129, nitrate, and tritium are essentially the only constituents that have been detected in groundwater that cannot be explained as anything but contamination. All four of these constituents are also associated with widespread (sitewide) contamination plumes. Tritium and nitrate show areal distributions that suggest they originate, at least in part, from the B Pond (see Hartman et al. 2000). However, arsenic and iodine-129 have been detected primarily in wells at the western extremity of the B Pond network, and have not been identified as components of the B Pond waste stream.

Anionic species, often complexed with radionuclides, predominated the waste streams sent to the B Pond. Nitrate is still present in groundwater beneath the facility, and has recently shown a reversal in a generally downward trend in some monitoring wells (see Section 3.0). For these reasons, specific conductance of groundwater samples should be measured as part of a B Pond monitoring program. 


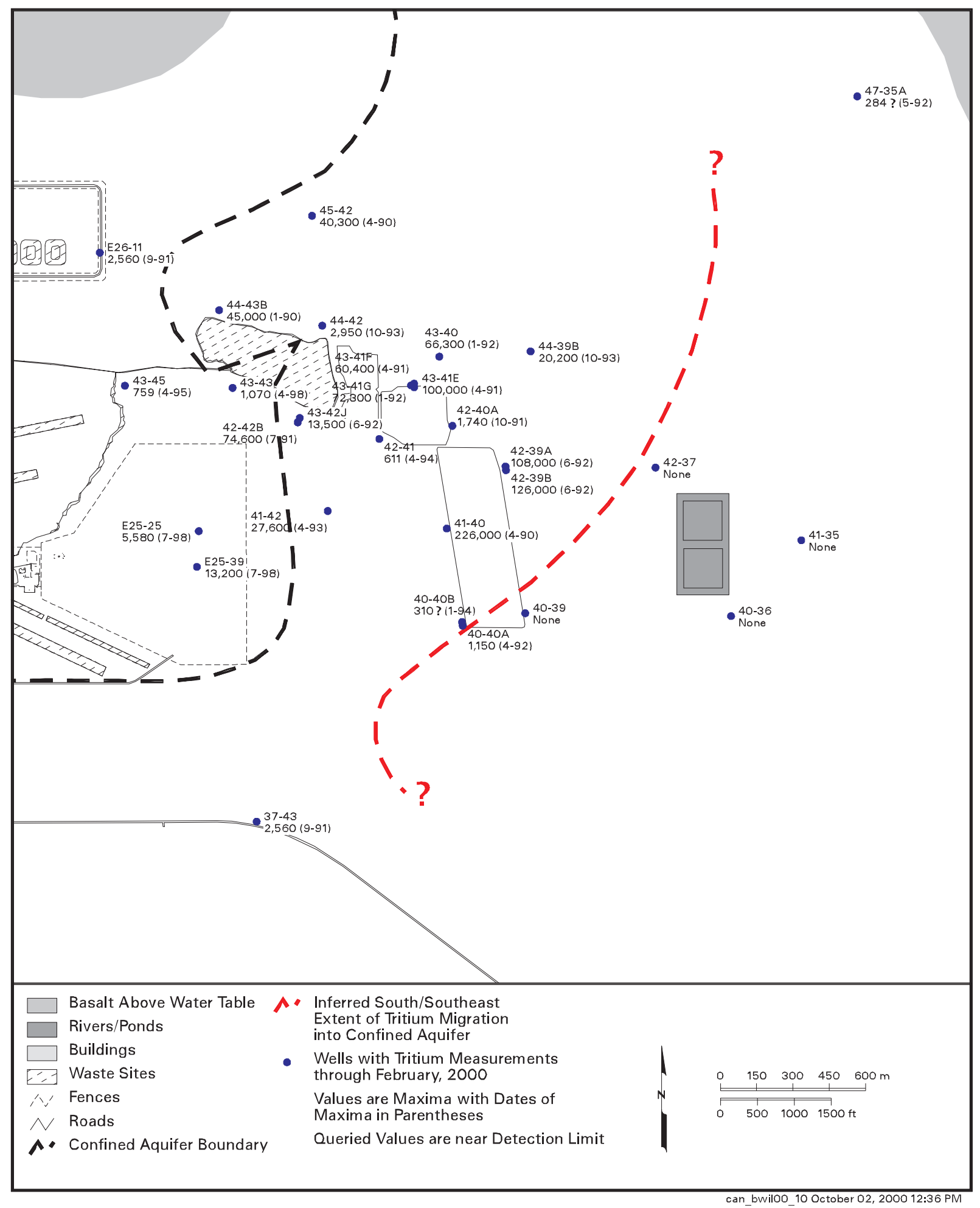

Figure 4.2. Tritium Maxima in B Pond and Vicinity Wells Showing Extent of Tritium Migration in the Confined Aquifer 


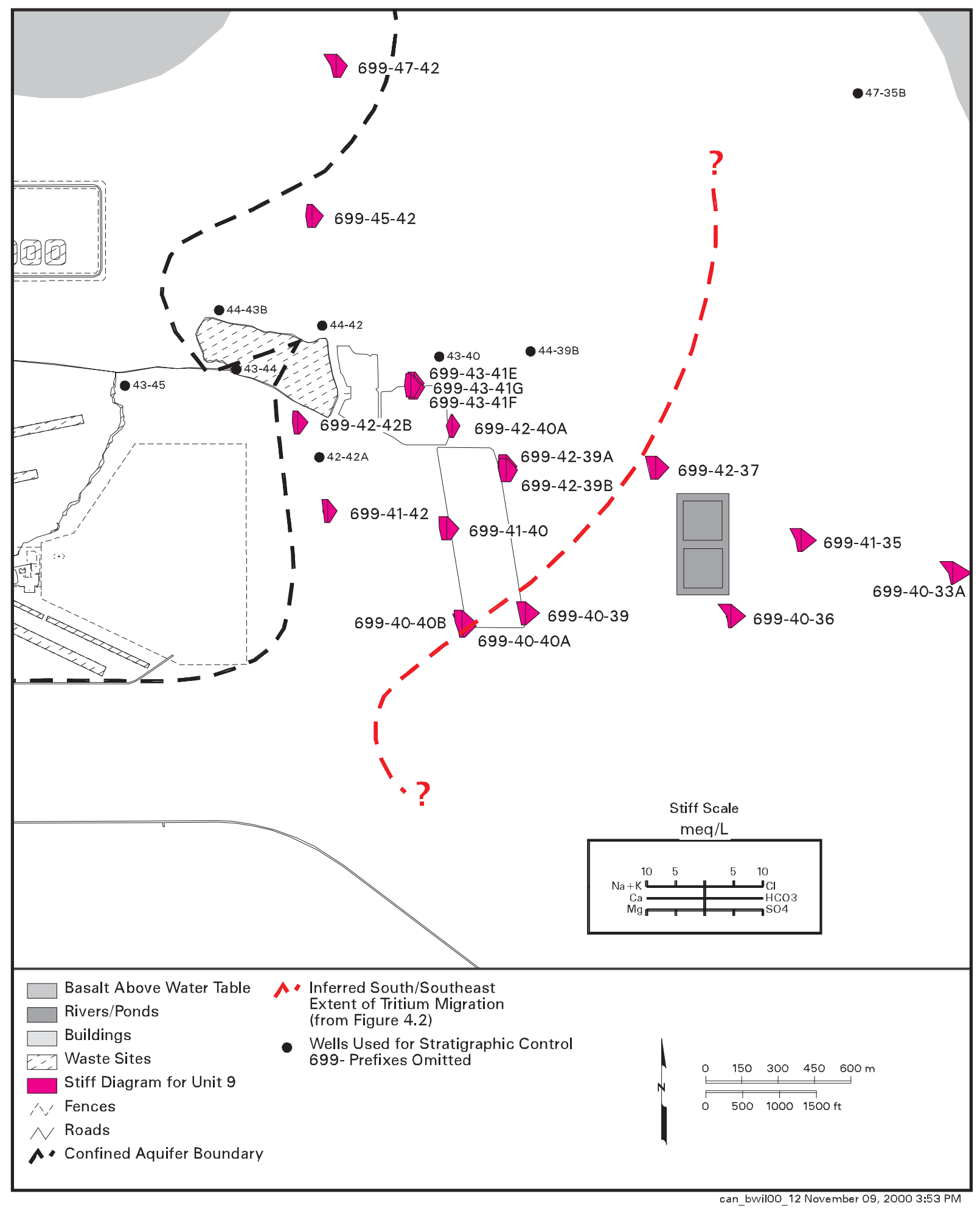

Figure 4.3. Major Ion Chemistry in Wells Completed in the Ringold Unit 9 in the Vicinity of B Pond (after Webber in Williams et al. 2000) 


\subsection{Conclusions and Recommendations}

The aquifer beneath the region of infiltration at the B Pond facility has been protected from direct effects of waste disposal not only by the impermeable lower mud unit, but by the relatively low hydraulic conductivity of the Ringold Formation aquifer itself. If tritium distribution is an indication, then apparently minimal migration has occurred to the east and southeast of the facility.

Very low levels of contamination are detected in soil and groundwater samples at B Pond. Conceptual models of contaminant fate (DOE/RL 1994; DOE/RL 2000) and subsequent soil chemistry and radiochemistry testing suggest that most of the contaminated effluent directed to the B Pond infiltrated in the ditches leading to the main pond, probably within the 200 East Area and in the main pond. The sources of risk for contamination reaching groundwater are from remobilization of existing contamination in the vadose zone beneath the main pond or effluent that has been intercepted in the vadose zone by the Ringold lower mud unit (Unit 8), which may then cascade off of this perching layer to enter the unconfined aquifer south of the main pond. Using or emplacing wells south to southwest of the main pond can monitor both of these potential sources under the current groundwater flow regime. Arsenic, gross alpha, gross beta, iodine-129, nitrate, specific conductance, and tritium are chosen as target constituents because these parameters are most likely to expose any residual contamination potentially remaining beneath the B Pond.

Monitoring specific conductance poses a special problem. Because of the dilutive effects of the large volumes of raw river water discharged to the facility, values for this parameter have been artificially depressed below natural background and are not currently in equilibrium with the solid phase of the aquifer. However, this parameter may be a useful indicator for contamination if Hanford Site background levels are reattained and later exceeded in B Pond wells (also see Sections 4.0, 6.3, 6.9.2, 6.9.3, and D.6). 


\subsection{Groundwater Monitoring Program}

This section describes a groundwater monitoring program consisting of a monitoring well network, target constituents, sampling and analysis methods, and a statistical approach for data evaluation. In 1988, RCRA monitoring at B Pond began in the interim status detection level phase of groundwater monitoring. In 1990, it was placed in assessment monitoring after TOX and TOC levels in downgradient wells exceeded critical concentration limits determined from the upgradient well. After extensive assessment monitoring, it was determined that the source for the elevated TOX and TOC levels had disappeared or was indeterminate (Barnett and Teel 1997). Consequently, B Pond returned to detection level monitoring in 1998. The elements of this monitoring program presented here were modified from the existing plan (Sweeney 1995) by incorporating recent evaluations of groundwater flow and chemistry at the B Pond facility with the major objectives to:

- protect human health and the environment

- comply with regulatory requirements (i.e., WAC 173-303-400 and 40 CFR 265 Subpart F) and agreements

- provide information for groundwater investigations and/or remediation.

RCRA groundwater monitoring efforts proposed for the B Pond will be consistent with the groundwater remediation strategy for the Hanford Site (DOE 1997a) and will be integrated with the sitewide monitoring activities where appropriate. In addition, an alternative monitoring and statistical approach based on final-status monitoring is proposed for discussion and possible future implementation, contingent upon concurrence by regulators.

\subsection{RCRA Interim-Status Regulatory Overview}

The U.S. Environmental Protection Agency (EPA) promulgated groundwater monitoring and response standards for certain land-based interim-status facilities in 1980 (45 FR 33232, May 19, 1980), codified in 40 CFR Part 265, Subpart F. Facility owners and operators are required to sample groundwater at specified intervals and to use a statistical procedure to determine whether or not hazardous wastes from these units are contaminating groundwater.

The Hanford Site is designated as a single RCRA facility and has been assigned a single identification number for the purpose of RCRA permitting activity. Because of the complexity of the Hanford Site, most of the RCRA-regulated units are interim-status facilities and will be brought into the Hanford Facility RCRA Permit (Ecology 1994) through a permit modification process. The B Pond is currently a RCRA interim-status facility, and a closure plan will be submitted to Ecology during 2001 for implementation by 2003. However, B Pond is currently an interim-status facility subject to inflexible sampling/ analysis requirements (i.e., contamination-indicator parameters). Historical sampling results and groundwater research at this facility indicate that these parameters are not the most appropriate for this site. To 
remedy this shortcoming, site-specific parameters are added. In addition, a brief description of a monitoring system that follows the final-status sampling and analysis requirements is also proposed, in anticipation that final-status monitoring may be implemented for greater efficiency. This contingent approach would also incorporate more appropriate data comparisons and statistical tests, and would apply to finalstatus monitoring at B Pond.

\subsection{Special Conditions at the B Pond}

The peculiar history of effluent discharges to the B pond facility, the complex geologic formations in which the aquifer beneath the facility is found, and the resulting hydrologic and hydrochemical conditions require special consideration in the formulation of an appropriate groundwater monitoring program. The conceptual model of Section 4.0 describes these peculiarities. The following elements of the plan are designed to detect contaminants with the greatest potential for occurrence in groundwater at the B Pond facility, and to address problems of groundwater geochemical equilibration, and high spatial variation in groundwater chemistry.

\subsection{Sampling and Analysis}

Table 5.1 lists the constituents to be analyzed under the B Pond facility groundwater monitoring program. Groundwater will be sampled for all constituents on a semiannual basis except the groundwater quality parameters, which will be sought annually.

Waste stream information and soil analyses (see Sections 1.5 and 1.6) indicate the possibility that some specific contaminants could impact groundwater quality at B Pond. Additionally, because B Pond remains an interim-status facility, contamination indicator parameters are retained as constituents to satisfy regulations. Based on these criteria, the B Pond will be monitored semiannually for $\mathrm{pH}$, specific conductance, total organic carbon, and total organic halides, gross alpha, and gross beta. Annual sampling will occur for chloride, iron, manganese, phenols, sodium, and sulfate. Additional field parameters; alkalinity, dissolved oxygen, temperature, and turbidity, will be sought as indicators of sample quality and general aquifer/well environmental conditions. Specific conductance, aside from being a regulatory requirement, will also be valuable in detecting complexants and ligands that are linked to B Pond operations.

Gross alpha and gross beta will be monitored semiannually as site-specific constituents, along with the indicator parameters required by regulations. These indicators will be monitored to detect whether radiogenic elements from the regulated unit (especially strontium-90 and cesium-137-those having greatest potential for contributing to contamination at the B Pond) have impacted groundwater beneath the site. These indicator species can only provide an indication of the presence of radioactive constituents in the groundwater. They cannot identify the specific constituent(s) that cause the degradation in groundwater quality. The specific constituents would be identified and concentration limits set should assessment or compliance monitoring be required. If additional constituents are identified, the groundwater monitoring plan will be revised in accordance with the most updated understanding of the site conditions. 
Table 5.1. Constituent List for the B Pond Facility

\begin{tabular}{||l||}
\hline Indicator Parameters \\
pH \\
Specific Conductance \\
Total Organic Carbon \\
Total Organic Halides \\
\\
Groundwater Quality Parameters ${ }^{(\mathbf{b})}$ \\
Chloride $^{(\mathrm{c})}$ \\
Iron \\
Manganese \\
Phenols \\
Sodium \\
Sulfate \\
(d) \\
Site-Specific Parameters \\
Gross alpha \\
Gross beta \\
Arsenic \\
Nitrate \\
Iodine-129 \\
Tritium \\
\end{tabular}

Arsenic, iodine-129, nitrate, and tritium are also identified as contaminants of concern in groundwater that could be associated with B pond operations. Because these constituents are also associated with existing, widespread sitewide plumes, they will be monitored on a regional scale by sitewide groundwater surveillance, and are not included specifically as constituents for B Pond. 


\subsection{Point of Compliance and Well Network}

The point of compliance (POC) is defined in 40 CFR 265.91 and WAC 173-303-645 (6) as a "vertical surface" located at the hydraulically downgradient limit of the waste management area that extends down into the uppermost aquifer underlying the regulated unit. For the B Pond, the POC will consist of the monitoring wells illustrated in Figure 5.1 (i.e., 699-43-45, 699-43-44, and 699-42-42B) and Table 5.2. These wells are directly downgradient of the facility, including the regulated portion of the B-3-3 ditch. Most of the wells in Figure 5.1 near the B Pond (see Figure 1.2) may be used for tracking the plumes of sitewide concern; arsenic, iodine-129, nitrate, and tritium, but are not specifically part of this monitoring plan.

An effective groundwater monitoring network of wells for the B Pond must account for the peculiar groundwater flow conditions existing at this facility. To ensure interception of any potential contamination the configuration of the network will need to consider not only the degree of areal coverage, but location of potential contamination in the vadose zone and aquifer (from main pond and B-3-3 ditch operation). More specifically, selection of wells for the revised groundwater monitoring network at the B Pond is based on:

- Areal distribution of wells in relation to the facility and the interpreted direction of groundwater flow in the confined and unconfined aquifers beneath and in the vicinity of the pond as prefaced by the conceptual model (Section 4.0). In deference to this criterion, a uniform spacing is otherwise attempted, recognizing that contaminants may potentially still be entrained in groundwater within the bounds of the facility, but with the qualification that the main pond and adjoining part of the B-3-3 ditch are the specific sources of potential contamination.

- The depth in the aquifer at which the wells are screened. As noted in Section 4.0, vertical differences in constituent concentrations are observed and must be accounted for qualitatively in network design. Wells are needed to monitor the confined aquifer in unit 9A as well as in the unconfined aquifer west and south of the pond.

- The expected life of the well, based on the water level and rate of decline; as discussed in Section 2.0, some wells have very limited projected life. Wells in the revised network are selected to optimize the balance between well life and the other attributes described here.

Using these guidelines, the revised groundwater monitoring network for the B Pond was derived, as shown in Figure 5.1. The proposed monitoring network for the B Pond consists of four wells; the construction details and lithologic logs of these wells are presented in Appendix C. The complex orientation of geologic strata beneath B Pond, and the unconfined and confined aquifers, makes well 699-44-39B, the most logical selection for an upgradient monitoring location. This well is completed in Ringold unit 9A, and is currently upgradient of the B Pond and the selected downgradient wells. Although groundwater flows under confined conditions in the vicinity of well 699-44-39B, this water discharges to the unconfined portion of the aquifer southwest and south of the main pond and B-3-3 ditch. 


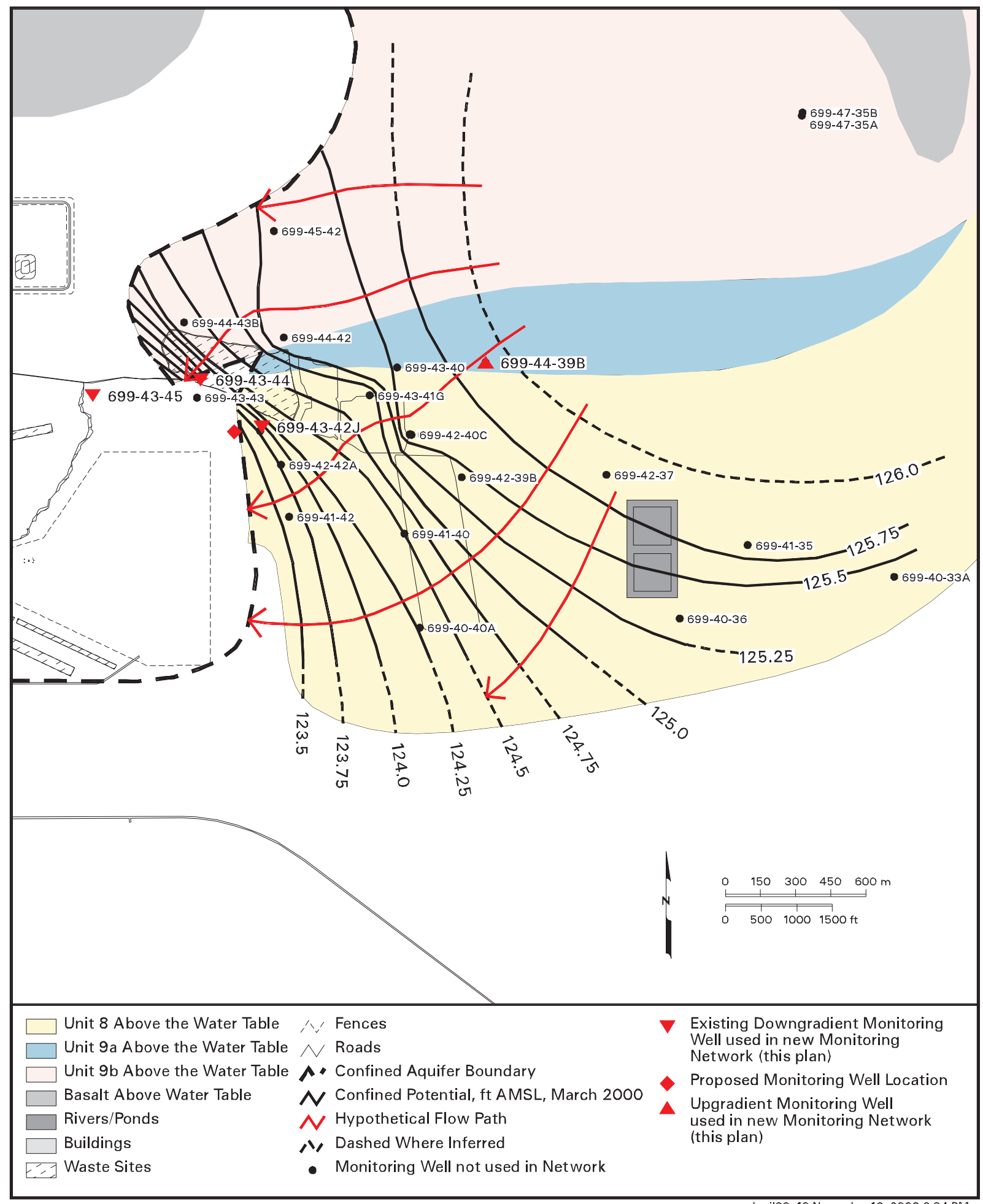

can bwil0o 19 November 10, 2000 2:34 PM

Figure 5.1. Location of Monitoring Wells in the Revised B Pond Network 
Table 5.2. Revised B Pond Groundwater Monitoring Well Network

\begin{tabular}{||l|l|l|l||}
\hline \multicolumn{1}{|c|}{ Well } & \multicolumn{1}{|c|}{ Date of Construction } & \multicolumn{1}{|c||}{ Units Monitored } & \multicolumn{1}{|c||}{$\begin{array}{c}\text { Estimated Years of } \\
\text { Service Left }^{\text {(a) }}\end{array}$} \\
\hline \hline $\begin{array}{l}\text { 699-44-39B } \\
\text { (upgradient) }\end{array}$ & September 1992 & $\begin{array}{l}\text { Ringold unit A-completed } \\
\text { below water table }\end{array}$ & 9 \\
\hline 699-42-42B & August 1988 & $\begin{array}{l}\text { Ringold unit A-completed } \\
\text { below water table }\end{array}$ & 20 \\
\hline $699-43-44$ & September 1999 & $\begin{array}{l}\text { Hanford formation- } \\
\text { completed at water table }\end{array}$ & $\begin{array}{l}\text { New well—no } \\
\text { estimate yet } \\
\text { available }\end{array}$ \\
\hline 699-43-45 & May 1989 & $\begin{array}{l}\text { Hanford formation- } \\
\text { completed at water table }\end{array}$ & 8.4 \\
\hline (a) As calculated in Table B.1, Appendix B.
\end{tabular}

Figure 5.1 also shows the approximate location of a new proposed well southwest of B Pond. Because of the complexity of the potential groundwater flow paths around B Pond, and the possibility that contaminants may be at lower levels in the aquifer, the new well in Figure 5.1 would be emplaced at a location that would:

- Intercept any contaminated groundwater spilling off of the lower mud confining unit (perching horizon) to the east and northeast of the well

- Detect contamination traveling in the aquifer (Ringold unit A [9A]) in a south to southwesterly direction.

- Detect contamination deeper within the aquifer. This would require a deep, or multiple-level completion, depending on the thickness of the aquifer at the selected location.

The proposed location shown is only approximate, and could change if groundwater flow patterns alter in the near term. Additionally, funding for new wells on the Hanford Site is prioritized according to perceived risk and negotiations between regulators and DOE. The location, depth, and other details of the new well will be resolved when these issues are resolved.

\subsection{Compliance Period}

Typically, groundwater monitoring is required during the active life of the regulated unit and for a period of 30 years following completion of closure activities if not clean closed, although this period may be shortened or extended by the regulatory authority. The compliance period begins when the owner or operator initiates a compliance monitoring program [WAC 173-303-645 (7)(b)]. If the regulated unit undergoes corrective action, then the compliance period will be extended until it can be demonstrated that the applicable limit(s) for constituents in groundwater has not been exceeded for a period of three consecutive years [WAC 173-303-645 (7)(c)]. 


\subsection{Sampling and Analysis Protocol}

Monitoring for the B Pond site is part of the Hanford Groundwater Monitoring Project. Procedures for groundwater sampling, documentation, sample preservation, shipment, and chain-of-custody requirements are described in PNNL or subcontractor manuals (e.g., Sampling Services Procedures Manual ${ }^{1}$ ) and in the quality assurance plan (PNNL $1998^{2}$ ). Samples generally are collected after three casing volumes of water have been purged from the well or after field parameters $(\mathrm{pH}$, temperature, specific conductance, and turbidity) have stabilized. Field parameters are measured in a flow-through chamber. Turbidities should be equal to or below $5 \mathrm{NTU}$ (nephlometric turbidity units; $1 \mathrm{NTU}=1 \mathrm{mg} / \mathrm{L}$ of solids) prior to sample collection. Sample preservatives are added to the collection bottles in the laboratory prior to their use in the field. Duplicates, trip blanks and field equipment blanks are collected as part of the general quality control program. The sampling and analysis methods and procedures and associated quality control results are described in more detail in Hartman et al. (2000). Samples to be analyzed for metals are usually filtered in the field so that results represent dissolved metals.

Procedures for field measurements are specified in the subcontractor's or manufacturer's manuals. Analytical methods are specified in contracts with laboratories, and most are standard methods from Test Methods for Evaluating Solid Wastes, Physical/Chemical Methods (EPA 1986a). Alternative procedures meet the guidelines of SW-846, Chapter 10.

\subsection{Quality Assurance and Quality Control}

The groundwater monitoring project's quality assurance/quality control (QA/QC) program is designed to assess and enhance the reliability and validity of groundwater data. The primary quantitative measures or parameters used to assess data quality are accuracy, precision, completeness, and the method detection limit. Qualitative measures include representativeness and comparability. Goals for data representativeness for groundwater monitoring projects are addressed qualitatively by the specification of well locations, well construction, sampling intervals, and sampling and analysis techniques in the groundwater monitoring plan for each RCRA facility. Comparability is the confidence with which one data set can be compared to another. The QC parameters are evaluated through laboratory checks (e.g., matrix spikes, laboratory blanks), replicate sampling and analysis, analysis of blind standards and blanks, and interlaboratory comparisons. Acceptance criteria have been established for each of these parameters, based on guidance from the U.S. Environmental Protection Agency (OSWER-9950.1, EPA 1986a). When a parameter is outside the criteria, corrective actions are taken to prevent a future occurrence and affected data are flagged in the database.

\subsection{Data Management, Evaluation, Interpretation, and Reporting}

This section describes how groundwater data are stored, retrieved, evaluated, and interpreted. Reporting of analytical results and interpretations thereof occurs as annual groundwater monitoring reports (e.g., Hartman et al. 2000) and as periodic letter reports to DOE.

\footnotetext{
${ }^{1}$ Waste Management Federal Services, ES-SSPM-001, 1998.

${ }^{2}$ The Hanford Groundwater Monitoring Project Quality Assurance Plan.
} 


\subsubsection{Data Management}

The contract laboratories report analytical results electronically. The results are loaded into the Hanford Environmental Information System (HEIS) database. Field-measured parameters are entered manually or through electronic transfer. Paper data reports and field records are considered to be the record copies and are stored at PNNL.

\subsubsection{Data Evaluation}

The data undergo a validation/verification process according to a documented procedure, as described in the project QA plan. QC data are evaluated against the criteria listed in the project QA plan and data flags are assigned when appropriate. In addition, data are screened by scientists familiar with the hydrogeology of the unit, compared to historical trends or spatial patterns, and flagged if they are not representative. Other checks on data may include comparison of general parameters to their specific counterparts (e.g., conductivity to ions; gross alpha to uranium), calculation of charge balances, and comparison of calculated vs measured conductivity. If necessary, the laboratory may be asked to check calculations or reanalyze the sample, or the well may be resampled.

\subsubsection{Data Interpretation}

After data are validated and verified, the acceptable data are used to interpret groundwater conditions at the site. Interpretive techniques include:

- Hydrographs: graph water levels versus time to determine decreases, increases, seasonal, or manmade fluctuations in groundwater levels.

- Water-table maps: use water-table elevations from multiple wells to construct contour maps to estimate flow directions. Groundwater flow is assumed to be perpendicular to lines of equal potential.

- Trend plots: graph concentrations of chemical or radiological constituents versus time to determine increases, decreases, and fluctuations. May be used in tandem with hydrographs and/or water-table maps to determine if concentrations relate to changes in water level or in groundwater flow directions.

- Plume maps: map distributions of chemical or radiological constituents areally in the aquifer to determine extent of contamination. Changes in plume distribution over time aid in determining movement of plumes and direction of flow.

- Contaminant ratios: can sometimes be used to distinguish between different sources of contamination. 


\subsection{Statistical Evaluation}

This section presents two approaches to statistical evaluation of data depending on whether the site is monitored under strict interim status detection level monitoring or under final-status type detection monitoring.

The goal of RCRA detection monitoring is to determine if the regulated unit has affected groundwater quality in the uppermost aquifer beneath the site. This is determined based on the results of statistical tests. According to 40 CFR 265.92 [and by reference of WAC 173-303-400(3)] the owner/operator of an interim-status hazardous waste facility must establish initial background concentrations for the contamination indicator parameters: specific conductance, $\mathrm{pH}, \mathrm{TOC}$, and TOX by obtaining at least four replicate measurements from each well quarterly for 1 year. Monitoring data (from January 1997 to June 2000) from the upgradient well 699-44-39B were used to determine the initial background arithmetic mean and variance. The expansion of the background period is deemed necessary because 4 quarters of monitoring data from one upgradient well are insufficient to provide reliable estimates of background mean and standard deviation. In addition, the resulting background values will be insensitive to real changes in groundwater quality. That is, 4 observations yield 3 degrees of freedom for the t-test that in turn will make the critical $t$ value too large to detect impact from the regulated unit (see discussion below).

Monitoring data collected after the first year are compared with the initial background data to determine if there is an indication that contamination may have occurred. A t-test is required to make this determination [40 CFR 265.93(b)]. A recommended method is the averaged replicate t-test method described in Appendix B of the RCRA Groundwater Monitoring Technical Enforcement Guidance Document (EPA 1986b). The averaged replicate t-test method for each contamination indicator parameter is calculated as:

$$
\mathrm{t}=\left(\overline{\mathrm{x}}_{\mathrm{i}}-\overline{\mathrm{x}}_{\mathrm{b}}\right) / \mathrm{S}_{\mathrm{b}} * \sqrt{1+1 / \mathrm{n}_{\mathrm{b}}}
$$

where $\mathrm{t}=$ test statistic

$\overline{\mathrm{x}}_{\mathrm{i}}=$ average of replicates from the $\mathrm{i}^{\text {th }}$ monitoring well

$\overline{\mathrm{x}}_{\mathrm{b}}=$ background average

$\mathrm{S}_{\mathrm{b}}=$ background standard deviation

$\mathrm{n}_{\mathrm{b}}=$ number of background replicate averages.

A test statistic larger than the Bonferroni critical value, $t_{c}$, (i.e., $t>t_{c}$ ) indicates a statistically significant probability of contamination. These Bonferroni critical values depend on the overall falsepositive rate required for each sampling period (i.e., $1 \%$ for interim status), the total number of wells in the monitoring network, and the number of degrees of freedom $\left(n_{b}-1\right)$ associated with the background standard deviation. Because of the nature of the test statistic in the above equation, results to be compared to background do not contribute to the estimate of the variance. The test can be reformulated, 
without prior knowledge of the results of the sample to be compared to background (i.e., $\overline{\mathrm{x}}_{\mathrm{i}}$ ), in such a way that a critical mean, CM, can be obtained:

$$
\begin{aligned}
& \mathrm{CM}=\overline{\mathrm{x}}_{\mathrm{b}}+\mathrm{t}_{\mathrm{c}} * \mathrm{~S}_{\mathrm{b}} * \sqrt{\left(1+1 / \mathrm{n}_{\mathrm{b}}\right)} \quad \text { (one tailed) } \\
& \mathrm{CM}=\overline{\mathrm{x}}_{\mathrm{b}} \pm \mathrm{t}_{\mathrm{c}} * \mathrm{~S}_{\mathrm{b}} * \sqrt{\left(1+1 / \mathrm{n}_{\mathrm{b}}\right)} \quad \text { (two tailed) }
\end{aligned}
$$

If downgradient data exceed the $\mathrm{CM}$, they are determined to be statistically different from background. For $\mathrm{pH}$, a two-tailed $\mathrm{CM}$ (or critical range) is calculated and downgradient data beyond the range are considered to be statistically different from background. If a statistical exceedance is detected, the well will be resampled to determine if the originally detected increase (or $\mathrm{pH}$ decrease) was a result of laboratory or measurement error (verification sampling). If verification sampling confirms the exceedance, the owner/operator must notify Ecology within 7 days and submit a groundwater quality assessment plan within 15 days following the notification [40 CFR 265.93(d)]. The goal of the assessment monitoring program is to determine if dangerous waste or dangerous waste constituents from the facility have entered the groundwater and, if so, to determine their concentration and the rate and extent of migration in groundwater [40 CFR 265.93(d)].

Critical mean values for the B Pond are presented in Table 5.3. It should be noted that TOC values obtained during January 2000 and June 2000 were excluded from the critical mean calculation because laboratory analyses yielded inconsistent results. Investigation of field blanks from the same periods also indicated there is a systematic bias in the laboratory TOC analyses. The problem is currently under investigation.

\subsection{Contingency for Alternative Monitoring Approach and Statistical Methods}

Sampling procedures and statistical evaluation method discussed in Section 5.9 are required to comply with interim status regulations as stipulated in 40 CFR 265 Subpart F (and by reference of WAC 173303-400). However, the t-test used is based on 4 replicate measurements and is flawed for the following reasons (see Davis and McNichols 1994 and Cameron 1996):

1. the required pooling of background data is not valid when spatial, temporal, and sampling variability constitute a significant portion of the total variability;

2. a static background is assumed because one initial set of background samples is collected and statistically compared to downgradient data collected during later monitoring

3. the background data pool does not incorporate any component of spatial variability if only one upgradient well is used

4. the four indicator parameters selected do not serve well as early warning indicators of incipient contamination of groundwater by leachate from the facility. 
Table 5.3. Critical Means for 16 Comparisons-Background Contamination Indicator Parameter Data for 216-B-3 Pond ${ }^{(a)}$

\begin{tabular}{|c|c|c|c|c|c|c|c|}
\hline Constituent, Unit & $\mathrm{n}$ & df & $t_{c}$ & $\begin{array}{c}\text { Average } \\
\text { Background }\end{array}$ & $\begin{array}{c}\text { Standard } \\
\text { Deviation }\end{array}$ & Critical Mean & $\begin{array}{c}\text { Upgradient/ } \\
\text { Downgradient } \\
\text { Comparison Value }\end{array}$ \\
\hline \begin{tabular}{|l} 
Specific \\
conductance, \\
$\mu \mathrm{S} / \mathrm{cm}$
\end{tabular} & 9 & 8 & 4.8643 & 258.694 & 24.828 & 386.0 & 386.0 \\
\hline Field $\mathrm{pH}$ & 9 & 8 & 5.4284 & 8.132 & 0.069 & {$[7.74,8.52]$} & {$[7.74,8.52]$} \\
\hline $\begin{array}{l}\text { Total organic } \\
\text { carbon, }{ }^{(\mathrm{c}, \mathrm{d})} \mu \mathrm{g} / \mathrm{L}\end{array}$ & 7 & $6^{(\mathrm{b})}$ & 5.7090 & 426.381 & 115.938 & $1,134.0$ & $1,142.8$ \\
\hline $\begin{array}{l}\text { Total organic } \\
\text { halides, }{ }^{(\mathrm{c}, \mathrm{d})} \mu \mathrm{g} / \mathrm{L}\end{array}$ & 9 & 8 & 4.8643 & 3.167 & 1.660 & 11.7 & 18.7 \\
\hline \multicolumn{8}{|c|}{\begin{tabular}{|l} 
(a) Data collected based on quarterly and semiannual sampling events from January 1997 to June 2000 for \\
upgradient well 699-44-39B. \\
(b) Outlier excluded. \\
(c) Critical mean calculated from values reported below vendor's specified method detection limit. \\
(d) Upgradient/downgradient comparison value is the most recent determined limit of quantitation based on the \\
second quarter FY 2000 blank results (see discussions in Appendix B, Hartman et al. 2000). \\
df $=$ Degrees of freedom (n-1). \\
$\mathrm{n}=$ Number of background replicate averages. \\
$\mathrm{t}_{\mathrm{c}}=$ Bonferroni critical t-value for appropriate df and 16 comparisons (4 wells x 4 indicator parameters).
\end{tabular}} \\
\hline
\end{tabular}

Because of the problems associated with the interim status requirements, other statistical evaluation methods are warranted and currently under consideration. One method, allowable under final status regulations WAC 173-303-645(8), is the use of a combined Shewhart-CUSUM control chart approach, first referenced by Westgard et al. (1977) and further developed by Lucas (1982). The method is also discussed in a groundwater context by Starks (1989), Gibbons (1994), and ASTM (1996) and first adopted into U.S. Environmental Protection Agency (EPA) guidance in 1989 (EPA 1989, 1992). This method is deemed the most viable alternative statistical test because:

- This is an intrawell method that compares each well in the monitoring system to its own history for each site-specific water quality parameter.

- No upgradient well is needed.

- This method is also useful in the case where an upgradient well exists, but there is a high degree of spatial variability in constituent concentrations among wells in a system.

- The method achieves a reasonable balance between false positive and false negative rates.

The path forward to a more flexible and technical sound sampling procedure and statistical evaluation methods is underway. Ecology has given general guidance for possible sitewide application of the method. However, formal agreements that address latitude in selecting monitoring parameters, methods of data comparisons, appropriate control limits, and variance on a facility basis are needed. When the 
remaining obstacles are resolved and a variance is granted by Ecology to deviate from interim status sampling and analysis requirements, Shewhart and CUSUM control limits for each constituents of interest will be proposed in an addendum or revision to this monitoring plan. 


\subsection{References}

- Public Laws

Comprehensive Environmental Response, Compensation, and Liability Act of 1980, as amended, Public Law 96-510, 94 Stat. 2767, 42 USC 9601 et seq.

Resource Conservation and Recovery Act of 1976, as amended, Public Law 94-580, 90 Stat. 2795, 42 USC 6901 et seq.

- Code of Federal Regulations

40 CFR 258, Code of Federal Regulations, Title 40, Part 258. Solid Waste Facility Criteria.

40 CFR 264, Code of Federal Regulations, Title 40, Part 264, Subpart F. Standards for Owners of Hazardous Waste Treatment, Storage, and Disposal Facilities.

40 CFR 265, Code of Federal Regulations, Title 40, Part 265, Subpart F. Interim Status Standards for Owners of Hazardous Waste Treatment, Storage, and Disposal Facilities.

- Federal Register

45 FR 33232. May 19, 1980. “Hazardous Waste and Consolidated Permit Regulations.” Federal Register.

47 FR 32350. July 26, 1982. Part 2. "Hazardous Waste Management System; Permitting Requirements for Land Disposal Facilities." Federal Register.

53 FR 39720. October 11, 1988. "Statistical Methods for Evaluating Ground-Water Monitoring Data from Hazardous Waste Facilities.” Federal Register.

- Washington Administrative Code

WAC 173-160, Washington Administrative Code. Minimum Standards for Construction and Maintenance of Wells. Olympia, Washington.

WAC 173-340, Washington Administrative Code. Model Toxics Control Act-Cleanup. Olympia, Washington.

WAC 173-303-400, Washington Administrative Code. Interim Status Facility Standards. Olympia, Washington. 
WAC 173-303-645, Washington Administrative Code. Releases from Regulated Units. Olympia, Washington.

\section{Others}

ASTM. 1996. Provisional Standard Guide for Developing Appropriate Statistical Approaches for Groundwater Detection Monitoring Programs, Committee D-18 on Soil and Rock, Designation PS 64-96, American Society for Testing and Materials, West Coshocton, Pennsylvania.

Barnett, D. B., and S. S. Teel. 1997. Results of RCRA Groundwater Quality Assessment at the 216-B-3 Pond Facility. PNNL-11604, Pacific Northwest National Laboratory, Richland, Washington.

Barnett, D. B., M. P. Bergeron, C. R. Cole, M. D. Freshley, and S. K. Wurstner. 1997. Tritium Monitoring in Groundwater and Evaluation of Model Predictions for the Hanford Site 200 Area Effluent Treatment Facility. PNNL-11665, Pacific Northwest National Laboratory, Richland, Washington.

Barnett, D. B. 1998. Evaluation of Groundwater Monitoring Results at the Hanford Site 200 Area Treated Effluent Disposal Facility. PNNL-11986, Pacific Northwest National Laboratory, Richland, Washington.

Barnett, D. B., and C. J. Chou. 1998. Groundwater Monitoring Plan for the Hanford Site 216-B-3 Pond RCRA Facility. PNNL-11903, Pacific Northwest National Laboratory, Richland, Washington.

Barnett, D. B. 2000. Groundwater Monitoring Plan for the Hanford Site 200 Area Treated Effluent Disposal Facility. Pacific Northwest National Laboratory, Richland, Washington.

Cameron, K., MD. 1996. "RCRA Leapfrog: How Statistics Shape and in Turn are Shaped by Regulatory Mandates.” Remediation 7(1)15-25.

Cearlock, C. S., K. M. Singleton, M. E. Todd, and D. B. Barnett. 2000. 200-CW-1 Operable Unit Borehole/Test Pit Summary. BHI-01367, Rev. 0. Bechtel Hanford Inc., Richland, Washington.

Conover, W. J. 1980. Practical Nonparametric Statistics, John Wiley \& Sons, Inc., New York.

Davis, C. B., and R. J. McNichols. 1994. "Groundwater Monitoring Statistics Update: Part I: Progress Since 1988." Groundwater Monitoring Review, pp. 148-158.

Davis, J. D., D. B. Barnett, L. C. Swanson, W. J. McMahon, and C. D. Palomares. 1993. Site Characterization Report: Results of Detailed Evaluation of the Suitability of the Site Proposed for Disposal of 200 Areas Treated Effluent. WHC-SD-EN-ES-004, Westinghouse Hanford Company, Richland, Washington.

Dirkes, R. L., and R. W. Hanf. 1996. Hanford Site 1995 Environmental Report. PNNL-11139, Pacific Northwest National Laboratory, Richland, Washington. 
DOE-RL. 1990. 216-B-3 Pond System Closure/Post Closure Plan. DOE/RL-89-28, Rev. 0, U.S. Department of Energy, Richland Operations Office, Richland, Washington.

DOE-RL. 1993a. B Plant Source Aggregate Area Management Study Report. DOE/RL-92-05, Rev. 0, U.S. Department of Energy, Richland Operations Office, Richland, Washington.

DOE-RL. 1993b. 216-B-3 Expansion Ponds Closure Plan. DOE/RL-89-28, Rev. 1, U.S. Department of Energy, Richland Operations Office, Richland, Washington.

DOE-RL. 1994. 200-BP-11 Operable Unit and 216-B-3 Main Pond Work/Closure Plan, Hanford Site, Richland, Washington, Volume 1: Field Investigation and Sampling Strategy. U.S. Department of Energy, Richland Operations Office, Richland, Washington.

DOE-RL. 1997. Hanford Site Background: Part 3, Groundwater Background. DOE/RL-96-61, Revision 0, U.S. Department of Energy, Richland Operations Office, Richland, Washington.

DOE-RL. 2000. 200-CW-1 Operable Unit RI/FS Work Plan and 216-B-3 RCRA TSD Unit Sampling Plan. DOE/RL-99-07. U.S. Department of Energy, Richland Operations Office, Richland, Washington.

Ecology - Washington State Department of Ecology, U.S. Environmental Protection Agency, and U.S. Department of Energy. 1998. Hanford Federal Facility Agreement and Consent Order. Document No. 89-10, Rev. 5 (The Tri-Party Agreement), Olympia, Washington.

Ecology. 1994. Dangerous Waste Portion of the Resource Conservation and Recovery Act Permit for the Treatment, Storage, and Disposal of Dangerous Waste, as amended. Permit Number 7890008967, effective September 28, 1994, Olympia, Washington.

EPA. 1986a. Test Methods for Evaluating Solid Wastes: Physical/Chemical Methods, $3^{\text {rd }}$ ed. SW-846, Office of Solid Waste and Emergency Response, Washington, D.C.

EPA. 1986b. RCRA Ground Water Monitoring Technical Enforcement Guidance Document (TEGD). Printed by National Water Well Association, Dublin, Ohio.

EPA. 1989. Statistical Analysis of Groundwater Monitoring Data at RCRA Facilities - Interim Final Guidance. PB89-151047, U.S. Environmental Protection Agency, Washington, D.C.

EPA. 1992. Statistical Analysis of Groundwater Monitoring Data at RCRA Facilities - Draft Addendum to Interim Final Guidance. EPA/530-R-93-003, U.S. Environmental Protection Agency, Washington, D.C.

EPA. 1994. Guidance for the Data Quality Objective Process. EPA QA/G-4, U.S. Environmental Protection Agency, Washington, D.C. 
Gibbons, R. D. 1994. Statistical Methods for Groundwater Monitoring. John Wiley and Sons, Inc., New York, pp. 15-16, 84-93.

Grubbs, F. E. 1969. "Procedures for Detecting Outlying Observations in Samples." Technometrics 11:1-21.

Harris, S. F. 1990. Ground Water Quality Assessment Plan for the 216-B-3 Pond System. WHC-SD-EN-AP-030, Westinghouse Hanford Company, Richland, Washington.

Hartman, M. J., and P. E. Dresel (eds). 1998. Hanford Site Groundwater Monitoring for Fiscal Year 1997. PNNL-11793, Pacific Northwest National Laboratory, Richland, Washington.

Hartman, M. J., L. F. Morasch, and W. D. Webber (eds). 2000. Hanford Site Groundwater Monitoring for Fiscal Year 1999. PNNL-13116, Pacific Northwest National Laboratory, Richland, Washington.

Johnson, V. G. 1993. Westinghouse Hanford Company Operational Groundwater Status Report, 19901992. WHC-EP-0595, Westinghouse Hanford Company, Richland, Washington.

Johnson, V. G., A. G. Law, S. P. Reidel, S. D. Evelo, D. B. Barnett, and M. D. Sweeney. 1995. Groundwater Impact Assessment Report for the 216-B-3 Pond System. WHC-EP-0813, Westinghouse Hanford Company, Richland, Washington.

Kramer, C. D. 1991. Phase I Characterization of the 216-B-3 Pond System. WHC-SD-EN-AP-042, Westinghouse Hanford Company, Richland, Washington.

Lindsey, K. A., B. N. Bjornstad, J. W. Lindberg, and K. M. Hoffman. 1992. Geologic Setting of the 200 East Area: An Update. WHC-SD-EN-TI-012, Westinghouse Hanford Company, Richland, Washington.

Lucas, J. M. 1982. “Combined Shewart-CUSUM Quality Control Schemes.” Journal of Quality Technology 14:51-59.

Luttrell, S. P. 1989. 216-B-3 Pond, In RCRA Ground-Water Monitoring Projects for Hanford Facilities: Annual Progress Report for 1988. R. M. Fruland and R. E. Lundgren (eds.). PNL-6852, Pacific Northwest Laboratory, Richland, Washington.

Ostle, B., and L. C. Malone. 1988. Statistics in Research: Basic Concepts and Techniques for Research Workers, Fourth Edition. Iowa State University Press, Ames, Iowa, pp. 66-67.

Starks, T. H. 1989. Evaluation of Control Chart Methodologies for RCRA Waste Sites. USEPA Technical Report CR814342-01-3, U.S. Environmental Protection Agency, Las Vegas, Nevada. Sweeney, M. D. 1995. Interim Status Groundwater Monitoring Plan for the 216-B-3 Pond. WHC-SD-EN-AP-013, Rev. 1, Westinghouse Hanford Company, Richland, Washington. 
Thorne, P. D., M. A. Chamness, V. R. Vermeul, Q. C. Madonald, and S. E. Schubert. 1994. ThreeDimensional Conceptual Model for the Hanford Site Unconfined Aquifer System. FY 1994 Status Report. PNL-10195, Pacific Northwest Laboratory, Richland, Washington.

Westgard, J. O., T. Groth, T. Aronson, and C. De Verdier. 1977. Combined Shewhart-CUSUM Control Chart for Improved Quality Control in Clinical Chemistry, Clinical Chemistry 28(10)1881-1887.

WHC. 1989. Waste Stream Characterization Report, Vols. 1-4. WHC-EP-0287, Westinghouse Hanford Company, Richland, Washington.

WHC. 1990a. Liquid Effluent Study Final Project Report. WHC-EP-0367, Westinghouse Hanford Company, Richland, Washington.

WHC. 1990b. Interim Hydrogeologic Characterization Report for the 216-B-3 Pond. WHC-SD-ENEV-002, Westinghouse Hanford Company, Richland, Washington.

Williams, B. A., B. N. Bjornstad, R. Schalla, and W. D. Webber. 2000. Revised Hydrogeology for the Suprabasalt Aquifer System, 200-East Area and Vicinity, Hanford Site, Washington. PNNL-12261, Pacific Northwest Laboratory, Richland, Washington.

Wurstner, S. K., and M. D. Freshley. 1994. Predicted Impacts of Future Water Level Decline on Monitoring Wells Using a Ground-Water Model of the Hanford Site. PNL-10196, Pacific Northwest Laboratory, Richland, Washington. 


\section{Appendix A}

Historical Monitoring Well Network Information Summary for the B Pond 


\section{Appendix A}

\section{Historical Monitoring Well Network Information Summary for the B Pond}

The locations of these wells are shown in Figure 1.2. Shallow wells indicated in Table 1.1 are those

that are screened at or near the water table. Wells designated "deep" or "intermediate" were screened deeper within the uppermost aquifer. 
Table A.1. Groundwater Monitoring Wells Used at the 216-B-3 Pond System Since RCRA Monitoring Began in 1988

\begin{tabular}{|c|c|c|}
\hline Well & $\begin{array}{c}\text { Date of } \\
\text { Construction }\end{array}$ & Comments \\
\hline $299-18-1$ & 1988 & Upgradient monitoring well; dropped in 1996 \\
\hline 299-E26-11 & 1989 & Shared with LERF, completed at bottom of aquifer \\
\hline 299-E32-4 & 1987 & Upgradient monitoring well \\
\hline $699-40-36$ & 1992 & TEDF monitoring well ${ }^{(\mathrm{a})}$ \\
\hline $699-40-39$ & 1989 & Shallow well; dropped from monitoring network in 1995 \\
\hline $699-40-40 \mathrm{~A}$ & 1991 & Deep $^{(b)}$ companion to well $699-40-40 B$ \\
\hline 699-40-40B & 1991 & $\begin{array}{l}\text { Shallow companion to well 699-40-40A; dropped from } \\
\text { monitoring network in } 1995\end{array}$ \\
\hline $699-41-35$ & 1992 & TEDF monitoring well ${ }^{(\mathrm{a})}$ \\
\hline $699-41-40$ & 1989 & Shallow \\
\hline $699-41-42$ & 1992 & Deep \\
\hline $699-42-37$ & 1992 & TEDF monitoring well ${ }^{(a)}$ \\
\hline 699-42-39A & 1991 & $\begin{array}{l}\text { Shallow companion to well 699-42-39B; dropped from } \\
\text { monitoring network in } 1995\end{array}$ \\
\hline 699-42-39B & 1991 & Deep companion to well 699-42-39A \\
\hline $699-42-40 \mathrm{~A}$ & 1981 & Shallow; dropped from monitoring network in 1995 \\
\hline $699-42-41$ & 1991 & Shallow \\
\hline $699-42-42 B$ & 1988 & Deep companion to well $699-43-42 \mathrm{~J}$ \\
\hline $699-43-40$ & 1991 & Shallow \\
\hline $699-43-41 \mathrm{E}$ & 1989 & Shallow companion to wells $699-43-41 \mathrm{~F},-41 \mathrm{G}$ \\
\hline $699-43-41 \mathrm{~F}$ & 1989 & $\begin{array}{l}\text { Intermediate-depth companion to wells } 699-43-41 \mathrm{E},-41 \mathrm{G} \text {; } \\
\text { dropped from monitoring network in } 1995\end{array}$ \\
\hline $699-43-41 \mathrm{G}$ & 1991 & Deep companion to wells $699-43-41 \mathrm{E},-41 \mathrm{~F}$ \\
\hline $699-43-42 J$ & 1988 & $\begin{array}{l}\text { Shallow companion with well 699-42-42B; dropped from } \\
\text { monitoring network in } 1995\end{array}$ \\
\hline $699-43-43$ & 1988 & Shallow; dropped from monitoring network in 1995 \\
\hline $699-43-44$ & 1999 & "Deep," completed immediately above basalt \\
\hline $699-43-45$ & 1989 & Shallow \\
\hline 699-44-39B & 1992 & Deep \\
\hline $699-44-42$ & 1988 & Shallow; dropped from network in 1995 \\
\hline 699-44-43B & 1989 & Shallow \\
\hline \multicolumn{3}{|c|}{$\begin{array}{l}\text { (a) Included in B Pond monitoring network as a coordinated effort with TEDF until } 1995 . \\
\text { (b) The terms "Deep" "Intermediate" and "Shallow" indicate relative position within the aquifer of } \\
\text { the screened portions of wells (see Section 1.3). Shallow wells are generally completed across } \\
\text { the water table. } \\
\text { TEDF }=200 \text { Area Treated Effluent Disposal Facility. } \\
\text { Upgradient wells designated in italic. }\end{array}$} \\
\hline
\end{tabular}




\section{Appendix B}

\section{Hydrographs and Serviceability Information for Historical and Current B Pond Wells}




\section{Appendix B}

\section{Hydrographs and Serviceability Information for Historical and Current B Pond Wells}

The following hydrographs display water level trends in all wells historically used for groundwater monitoring at B Pond. These records include all water level data through March 2000. However, water levels in some wells have not been measured since 1997, and may be measured every three years or have not been used at all since the last shown measurement date.

Table B.1 provides predictions of well serviceability calculated from water level data. The table represents a linear calculation of water level decline in the B Pond wells for the most recent $\sim 1$ year of data, ending January 2000. The predicted years of service are based on the water remaining in the well divided by the rate of decline, assuming a minimum of 1 foot of water must remain in the well to be serviceable. Discrepancies occur within Table B.1 because of errors in as-built diagrams, estimates in pump intake depths, and conflicting information on well completion. In most cases, these discrepancies have resulted in wells going dry slightly before or after predicted. In the most extreme case, conflicting records between depth and pump intake in well 699-43-41F result in an apparent pump level occurring deeper than the bottom of the well. However, for purposes of estimating serviceability this table is still useful, particularly given the high rate of water level decline in most wells. Abbreviations are:

DTW $=$ depth to water

WT Elev = water table elevation

REF Elev= elevation reference (of the measurement point on the well casing)

All distances in Table B.1 are in feet, as they appear in the HEIS database. 

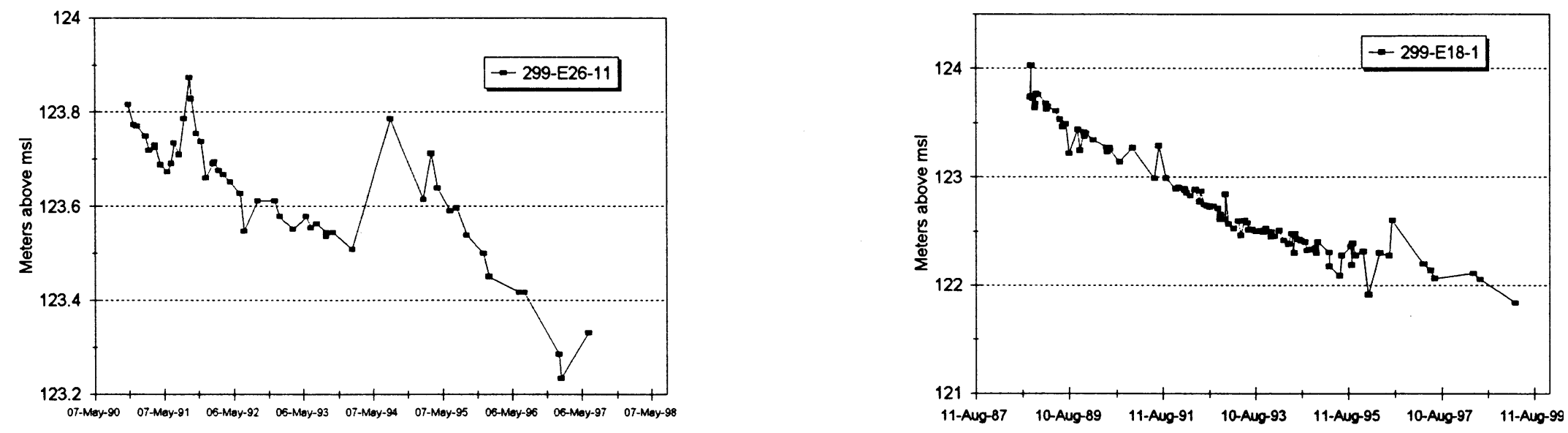

$\underset{N}{\infty}$
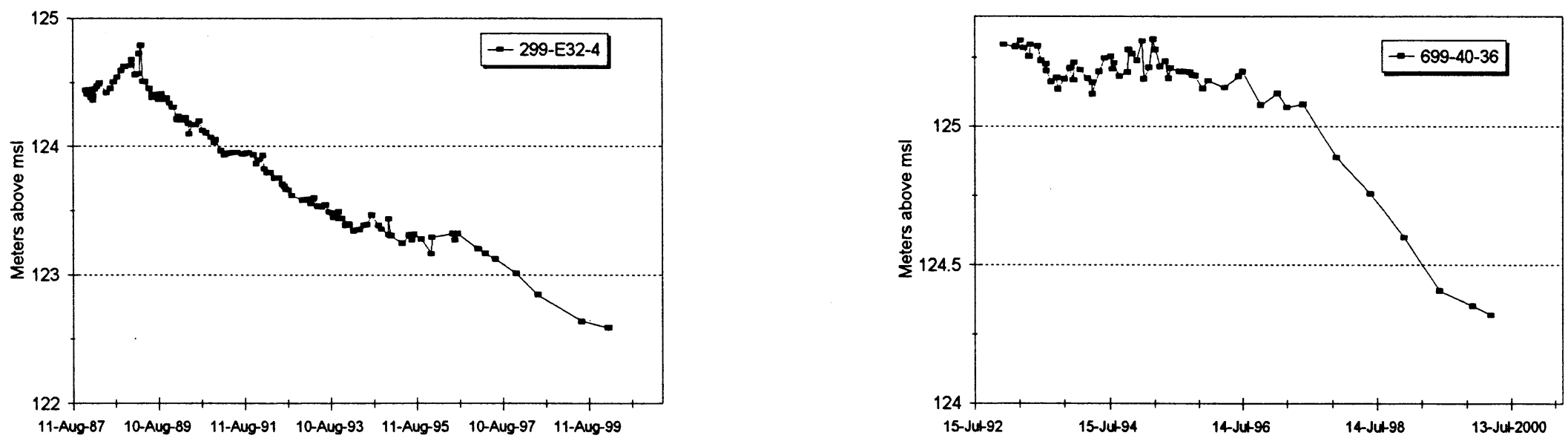


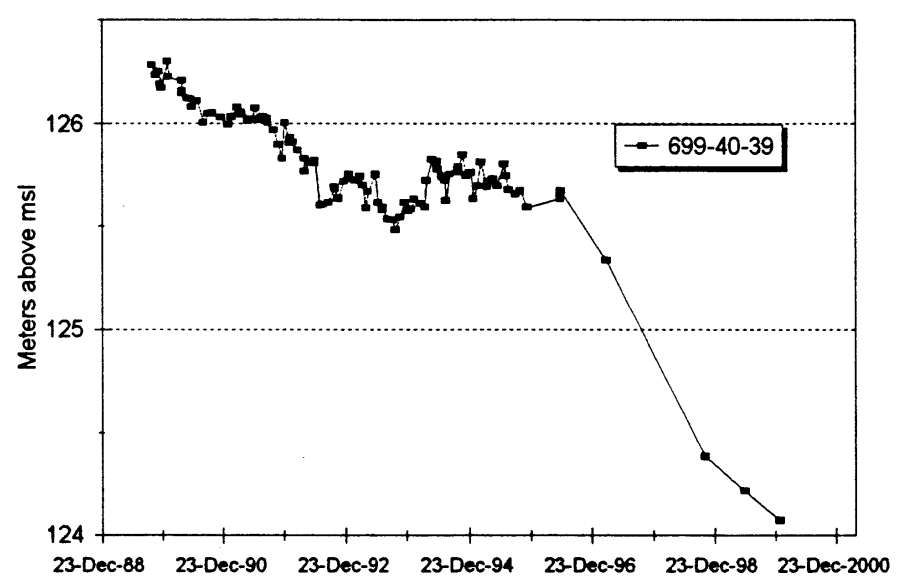

w

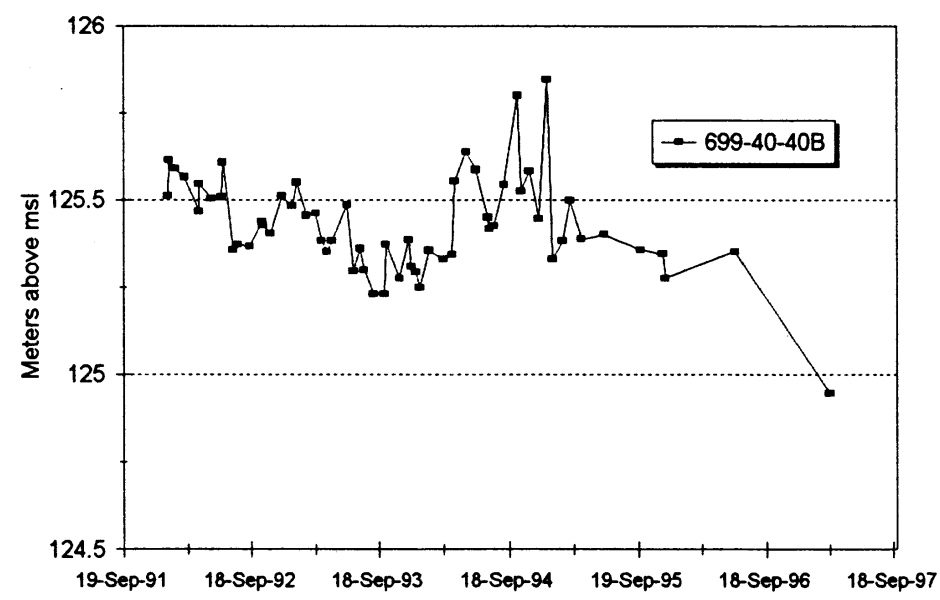

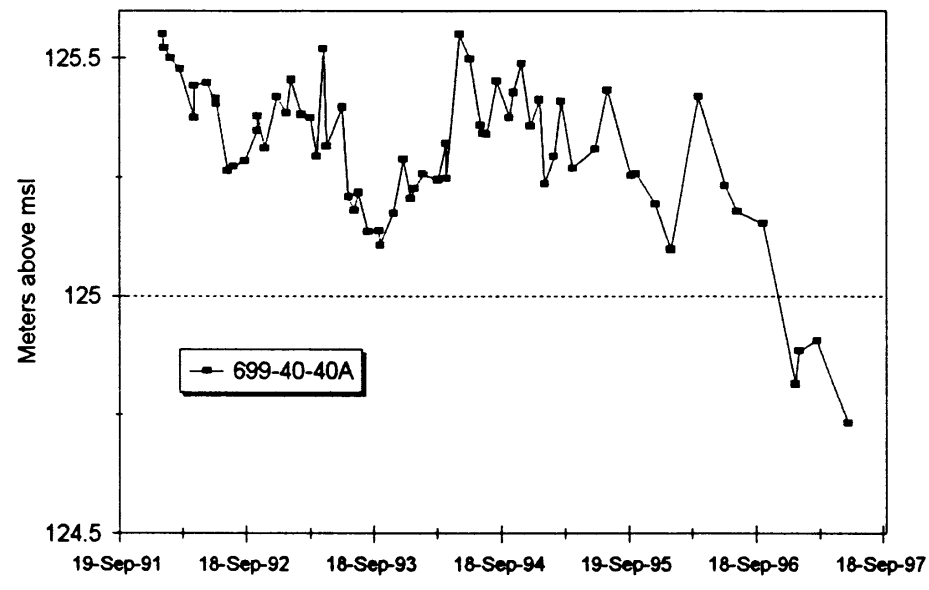

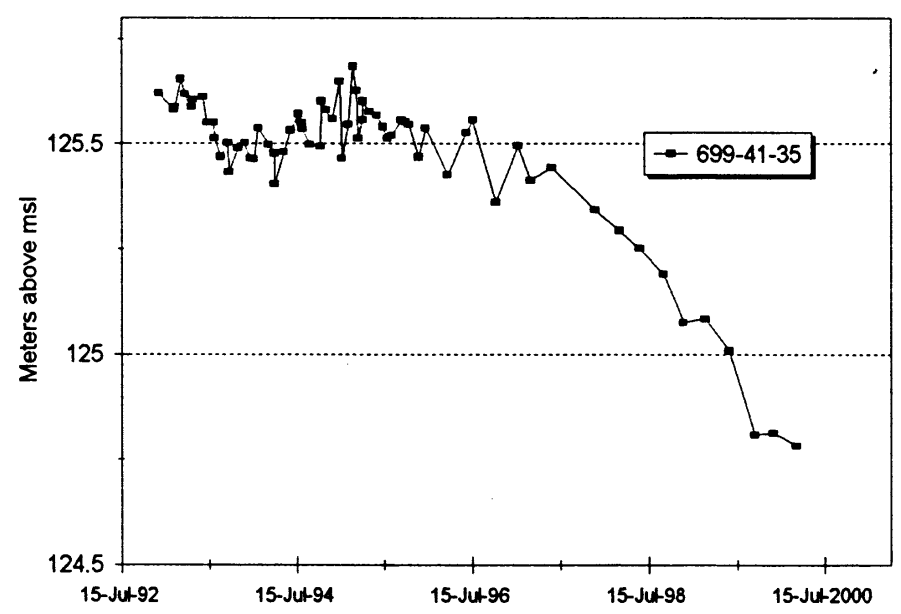



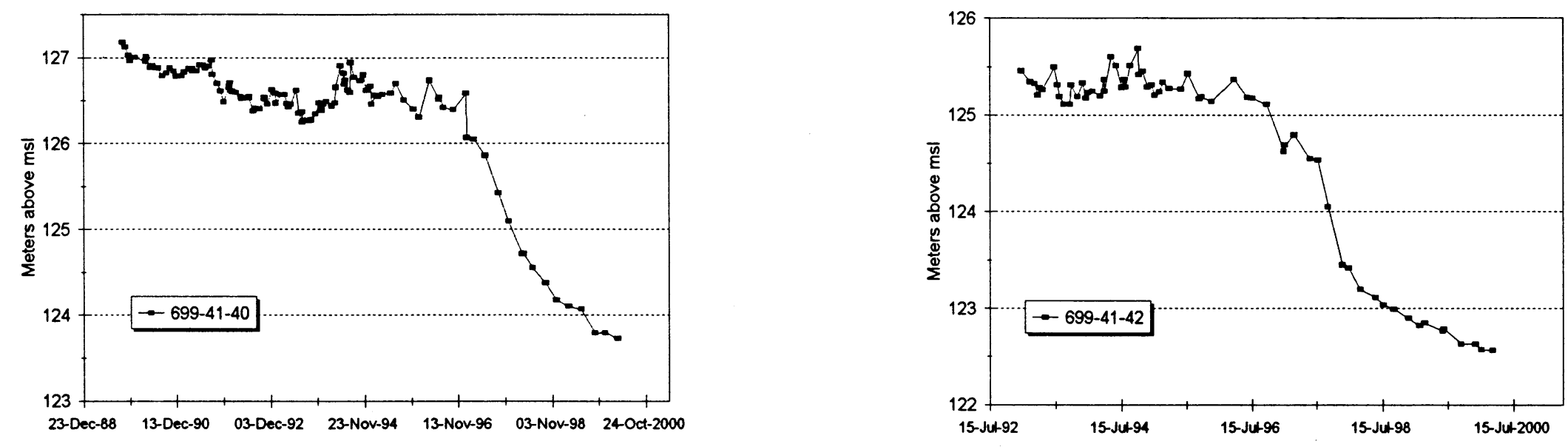

i
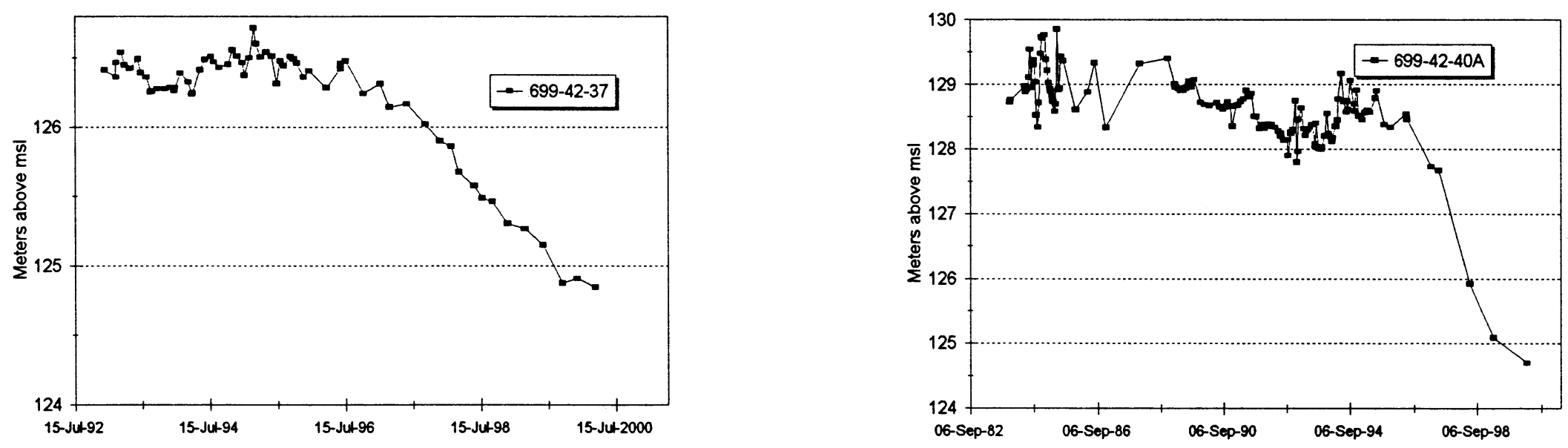

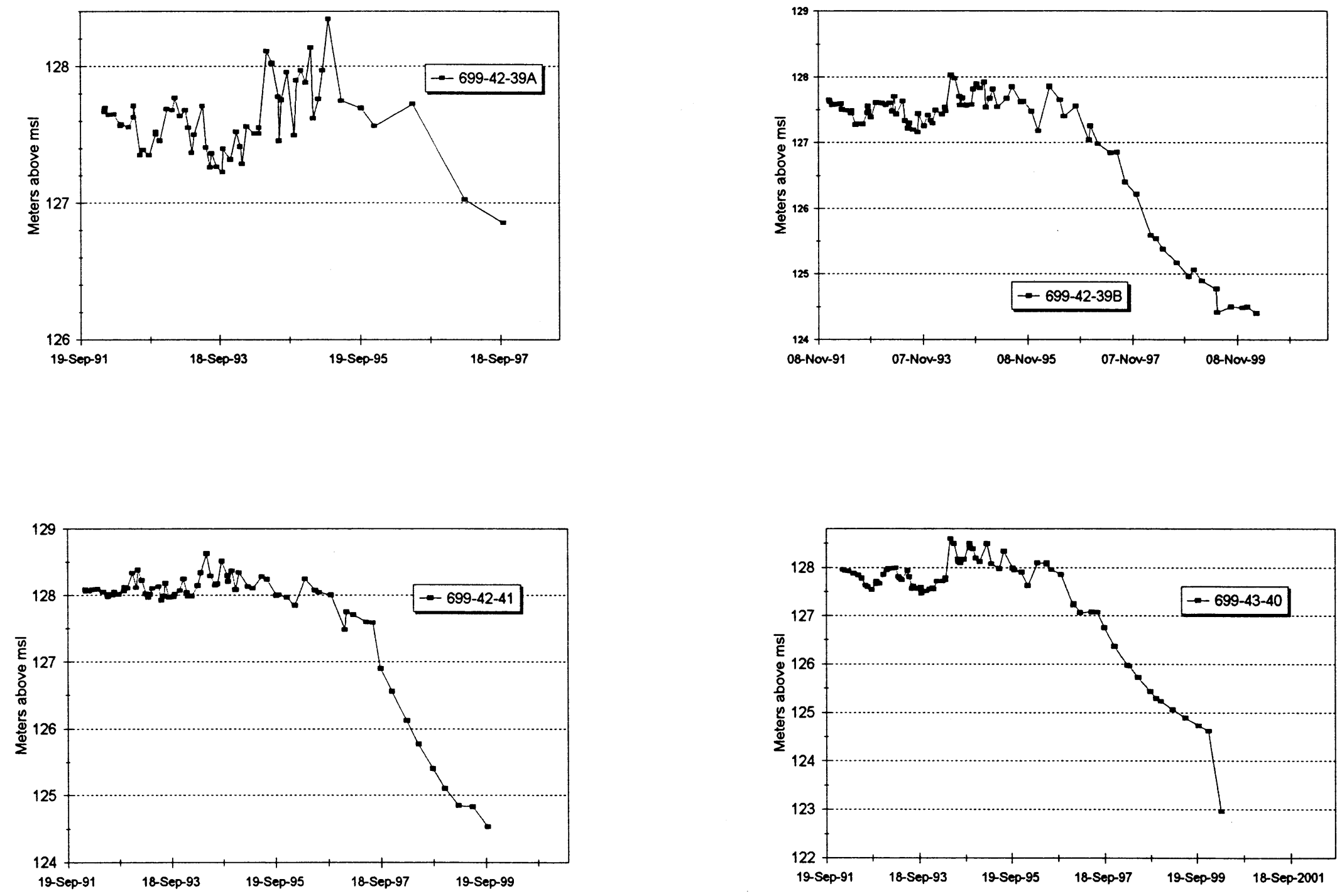

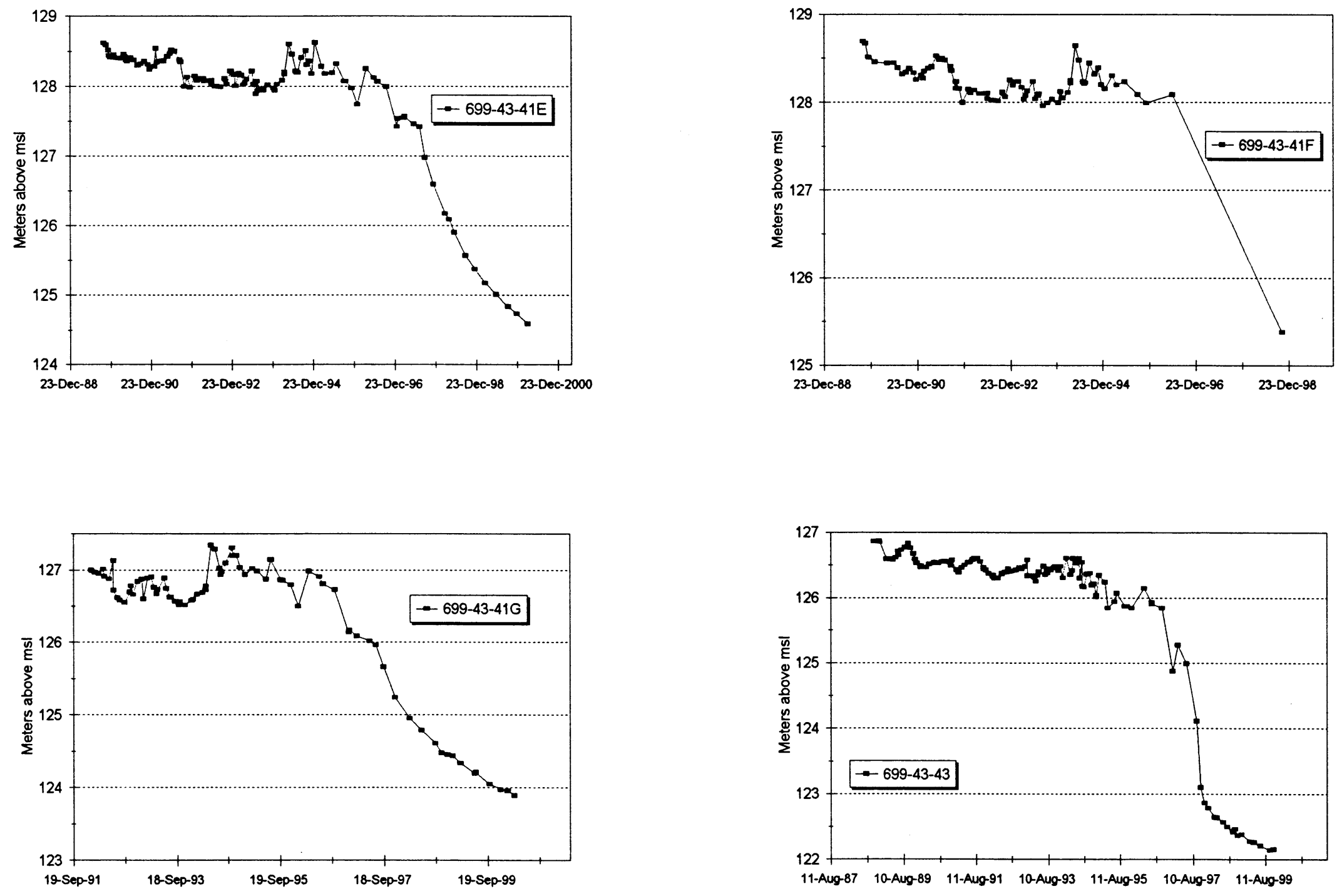

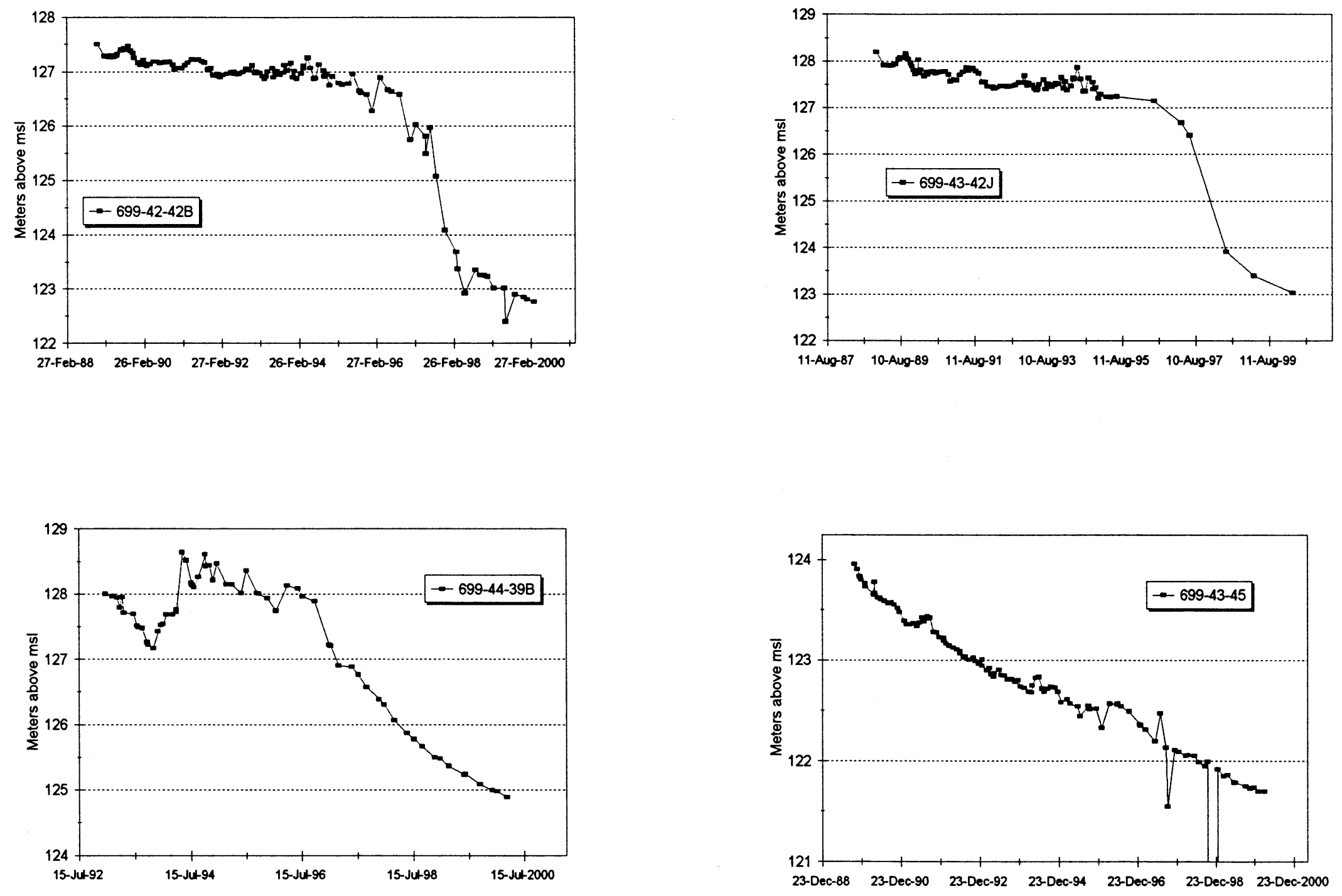

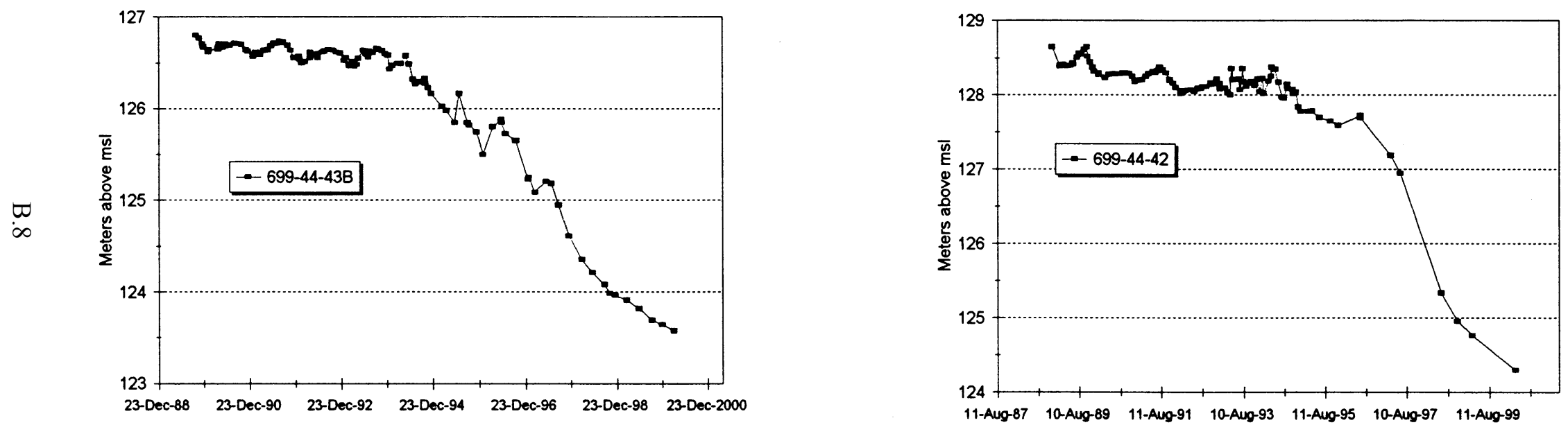
Table B.1. Well Information Serviceability

\begin{tabular}{|c|c|c|c|c|c|c|c|c|c|c|c|c|c|c|}
\hline Well & 98 Meas. Date & 99 Meas. Date & 98DTW & 99DTWf & WT Elev $\mathrm{ft}$ & Ref Elev $\mathrm{ft}$ & Depth of well & Depth of & Water left & Amount pump & Water left & Annual Rate & Years of & Change* \\
\hline & & & & & & & screen bottom & pump intake & above intake (fit) & can be lowered (ft) & in well & of decline (ft) & Service Left & \\
\hline 299-E18-1 & 09-Jun-98 & 10-Mar-99 & 320.09 & 320.8 & 399.44 & 720.24 & 332.20 & 323.93 & 3.13 & 8.27 & 11.40 & 0.95 & 11.0 & 0.62 \\
\hline 299-E32-4 & 03-Dec-98 & 17-Dec-99 & 286.52 & 286.86 & 402.64 & 689.50 & 298.00 & 296.00 & 9.14 & 2.00 & 11.14 & 0.33 & 31.0 & -0.22 \\
\hline $699-40-36$ & 07-Dec-98 & 17-Dec-99 & 120.12 & 120.93 & 407.99 & 528.92 & 222.95 & 216.75 & 95.82 & 6.20 & 102.02 & 0.79 & 128.1 & -0.26 \\
\hline $699-40-39$ & $29-0$ ct-98 & 23-Jun-99 & 133.78 & 134.31 & 407.53 & 541.84 & 218.10 & 209.00 & 74.69 & 9.10 & 83.79 & 0.82 & 101.4 & -1.12 \\
\hline $699-40-40 \mathrm{~A}$ & $07-$ Dec-98 & 17-Dec-99 & 135.82 & 136.72 & 404.49 & 541.21 & 229.55 & 218.92 & 82.20 & 10.63 & 92.83 & 0.88 & 104.8 & -2.17 \\
\hline $699-40-40 \mathrm{~B}$ & 21-Jun-96 & 19-Mar-97 & 130.92 & 132.26 & 409.92 & 542.18 & 201.30 & 193.72 & 61.46 & 7.58 & 69.04 & 1.80 & 37.7 & \\
\hline \begin{tabular}{|l}
$699-41-35$ \\
\end{tabular} & $07-$ Dec-98 & 17-Dec-99 & 110.17 & 111.03 & 409.35 & 520.38 & $\frac{203.80}{203.80}$ & 201.37 & 90.34 & $\frac{1.00}{2.43}$ & 92.77 & $\begin{array}{l}1.00 \\
0.84\end{array}$ & $\frac{3.1}{109.6}$ & 0.07 \\
\hline $699-41-40$ & 07-Dec-98 & 17-Dec-99 & 138.53 & 139.79 & 406.15 & 545.94 & 178.00 & 176.40 & 36.61 & 1.60 & 38.21 & 1.23 & 30.3 & -3.08 \\
\hline $699-41-42$ & 07-Dec-98 & 17-Dec-99 & 240.71 & 241.58 & 402.33 & 643.91 & 280.60 & 280.70 & 39.12 & 0.00 & 39.02 & 0.85 & 44.9 & -3.46 \\
\hline $699-42-37$ & $07-$ Dec-98 & 17-Dec-99 & 108.3 & 109.6 & 409.82 & 519.42 & 158.60 & 154.39 & 44.79 & 4.21 & 49.00 & 1.27 & 37.9 & -0.65 \\
\hline 699-42-39A & 19-Mar-97 & $03-0 c t-97$ & 141.41 & 141.93 & 416.21 & 558.14 & 179.90 & 173.53 & 31.60 & 6.37 & 37.97 & 0.96 & 38.6 & \\
\hline $699-42-39 B$ & $07-$ Dec-98 & 17-Dec-99 & 148.31 & 149.87 & 408.45 & 558.32 & 213.80 & 217.50 & 67.63 & 0.00 & 63.93 & 1.52 & 41.4 & -3.27 \\
\hline $699-42-40 A$ & 08-Jun-98 & 09-Mar-99 & 132.4 & 135.13 & 410.4 & 545.53 & 170.00 & 168.70 & 33.57 & 1.30 & 34.87 & 3.64 & 9.3 & -2.16 \\
\hline \begin{tabular}{|l|}
$699-42-41$ \\
\end{tabular} & $07-$ Dec-98 & 28-Sep-99 & 156.83 & 158.69 & 408.61 & 567.3 & 155.20 & 149.12 & 0.95 & 6.08 & -3.49 & 2.30 & -2.0 & -3.7 \\
\hline $699-42-42 B$ & 07-Dec-98 & 17-Dec-99 & 178.85 & 180.17 & 403.06 & 583.23 & 206.60 & 195.00 & 14.83 & 11.60 & 26.43 & 1.28 & 19.8 & -4.04 \\
\hline $699-43-40$ & 07-Dec-98 & 17-Dec-99 & 131.32 & 133.33 & 408.87 & 542.2 & 132.67 & 134.20 & 0.87 & -1.53 & -0.66 & 1.96 & -0.8 & -2.26 \\
\hline 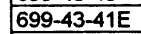 & $07-$ Dec-98 & 17-Dec-99 & 139.52 & 141.63 & 409.23 & 550.86 & 145.80 & 144.28 & 2.65 & 1.52 & 4.17 & 2.05 & 1.5 & -3.08 \\
\hline $699-43-41 \mathrm{~F}$ & 15-Jun-95 & $29-0$ ct-98 & 130.3 & 139.53 & 411.48 & 551.01 & 155.00 & 172.19 & 32.66 & -17.19 & 15.47 & 0.37 & 39.1 & \\
\hline $699-43-416$ & 07-Dec-98 & 17-Dec-99 & 143.02 & 144.58 & 406.76 & 551.34 & 202.70 & 193.70 & 49.12 & 9.00 & 58.12 & 1.52 & 37.6 & -2.1 \\
\hline $699-43-42 \mathrm{~J}$ & 09 -Jun- 98 & 09-Mar-99 & 174.97 & 176.68 & 405 & 581.68 & 177.40 & 175.50 & -1.18 & 1.9 & 0.72 & 2.29 & -0.1 & -5.7 \\
\hline $699-43-43$ & 29-Oct-98 & 28-Sep-99 & 177.74 & 178.47 & 400.9 & 579.37 & 180.80 & 177.00 & -1.47 & 3.80 & 2.33 & 0.80 & 1.7 & -4.22 \\
\hline 699-43-45 & $07-D e c-98$ & $10-$ Nov-99 & 197.66 & 198.12 & 399.56 & 597.68 & 203.30 & 200.30 & 2.18 & 3.00 & 5.18 & 0.50 & 8.4 & 0.03 \\
\hline $699-44-39 B$ & 07-Dec-98 & 17-Dec-99 & 101.64 & 103.3 & 410.1 & 513.4 & 118.90 & 117.40 & 14.10 & 1.5 & 15.60 & 1.6 & 9.0 & 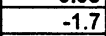 \\
\hline 699-44-42 & 29-Oct-98 & 09-Mar-99 & 169.12 & 169.74 & 409.48 & 579.22 & 175.00 & 161.00 & -8.74 & 14.00 & 5. & 1.73 & 2.5 & -2.9 \\
\hline 699-44-43B & 07-Dec-98 & 17-Dec-99 & 173.24 & 174.31 & 405.81 & 580.12 & 178.75 & 172.30 & -2.01 & 6.45 & 4.44 & 1.04 & 3.3 & -1.75 \\
\hline 299-E26-11 & 11-Jan-99 & 04-Jan-2000 & 196.08 & 196.87 & 403.6 & 599.68 & 205.90 & 206.20 & 9.33 & 0.00 & 9.03 & 0.81 & 10.0 & -0.01 \\
\hline
\end{tabular}

Calculations are based on most recent 1 year of available data.

*Change in rate of water level decline (in ft/year) between 1997-1998 and 1998-1999 calculations 


\section{Appendix C}

\section{Well Lithologic Logs and Construction Details}

The following diagrams illustrate specifications of well construction and the general lithologic records from the drilling of each of the four wells included in the revised B Pond groundwater monitoring network. All depths and distances are in feet, as they were recorded during the drilling of the wells. 


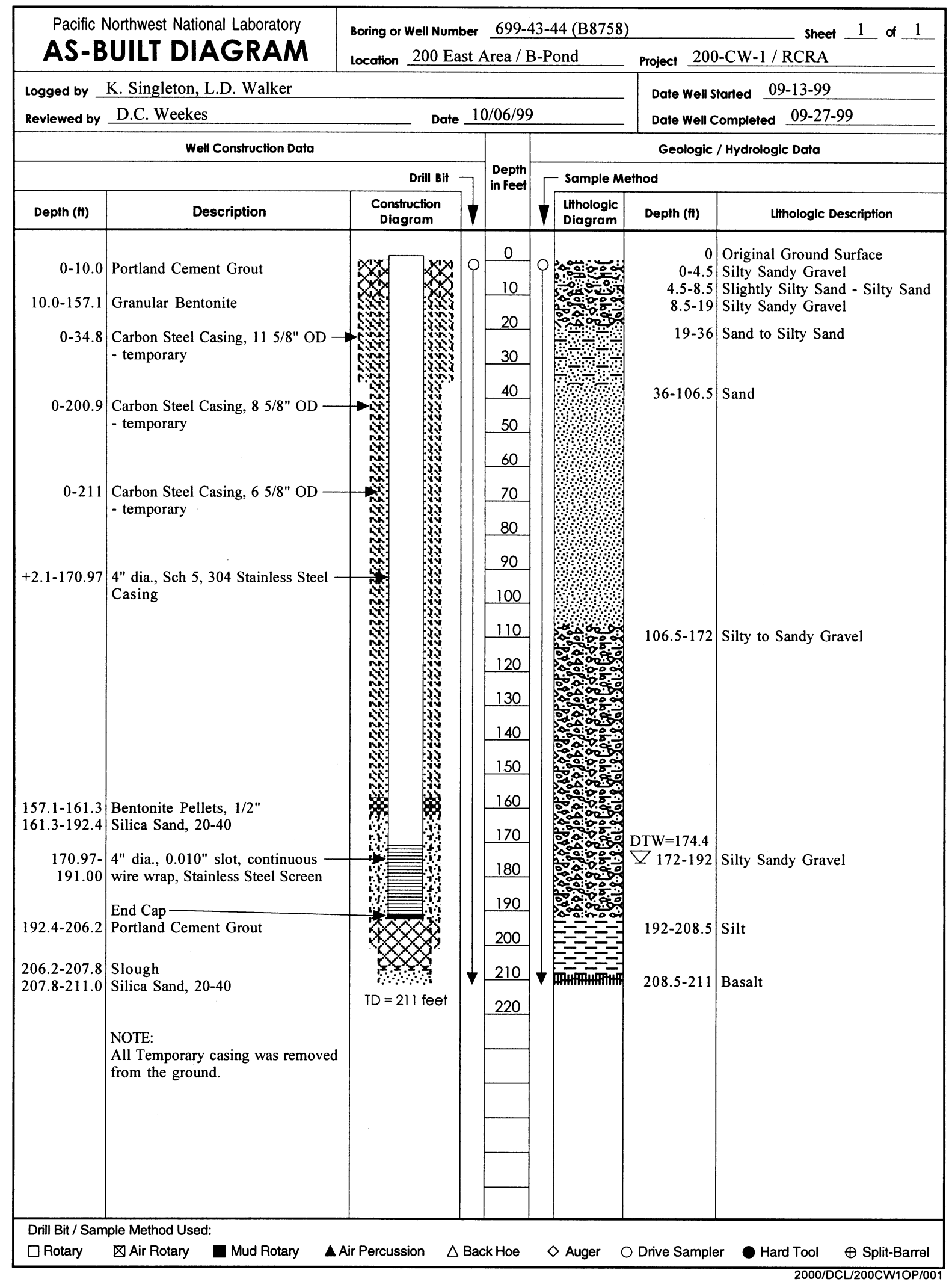




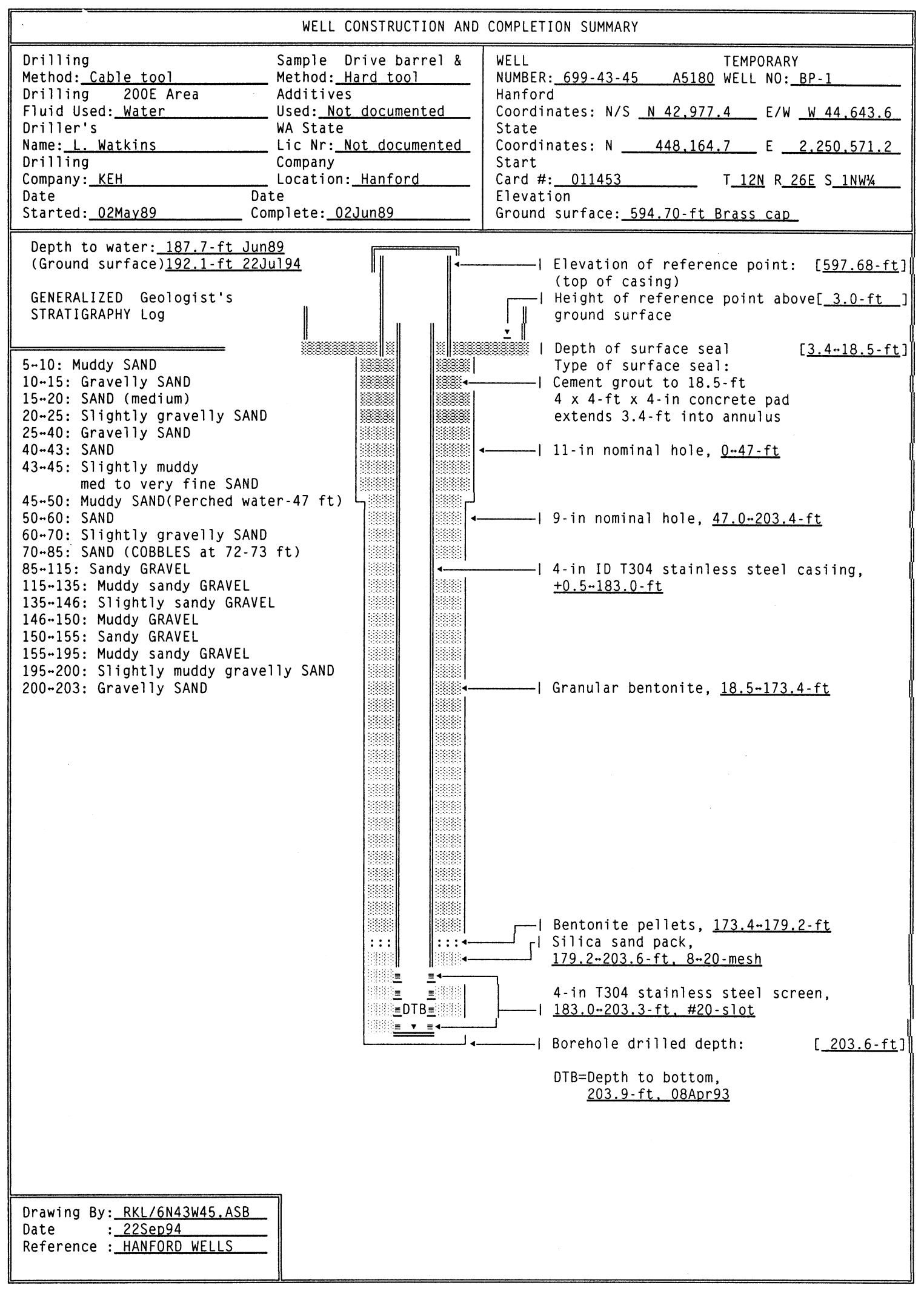




\section{SUMMARY OF CONSTRUCTION DATA AND FIELD OBSERVATIONS RESOURCE PROTECTION WELL - 699-43-45}

$\begin{array}{ll}\text { WELL DESIGNATION } & : \\ \text { RCRA FACILITY } & : \\ \text { CERCLA UNIT } & : \\ \text { HANFORD COORDINATES } & : \\ \text { LAMBERT COORDINATES } & : \\ \text { DATE DRILLED } & : \\ \text { DEPTH DRILLED (GS) } & : \\ \text { MEASURED DEPTH (GS) } & : \\ \text { DEPTH TO WATER (GS) } & : \\ \text { CASING DIAMETER } & : \\ \text { ELEV TOP CASING } & : \\ \text { ELEV GROUND SURFACE } & : \\ \text { PERFORATED INTERVAL } & : \\ \text { SCREENED INTERVAL } & : \\ \text { COMMENTS } & : \\ & \\ \text { ANTILABLE LOGS } & : \\ \text { TV SCAN COMMENTS } & : \\ \text { DATE EVALUATED } & : \\ \text { EVAL RECOMMENDATION } & : \\ \text { LISTED USE } & : \\ \text { CURRENT USER } & : \\ \text { PUMP TYPE } \\ \text { MAINTENANCE }\end{array}$

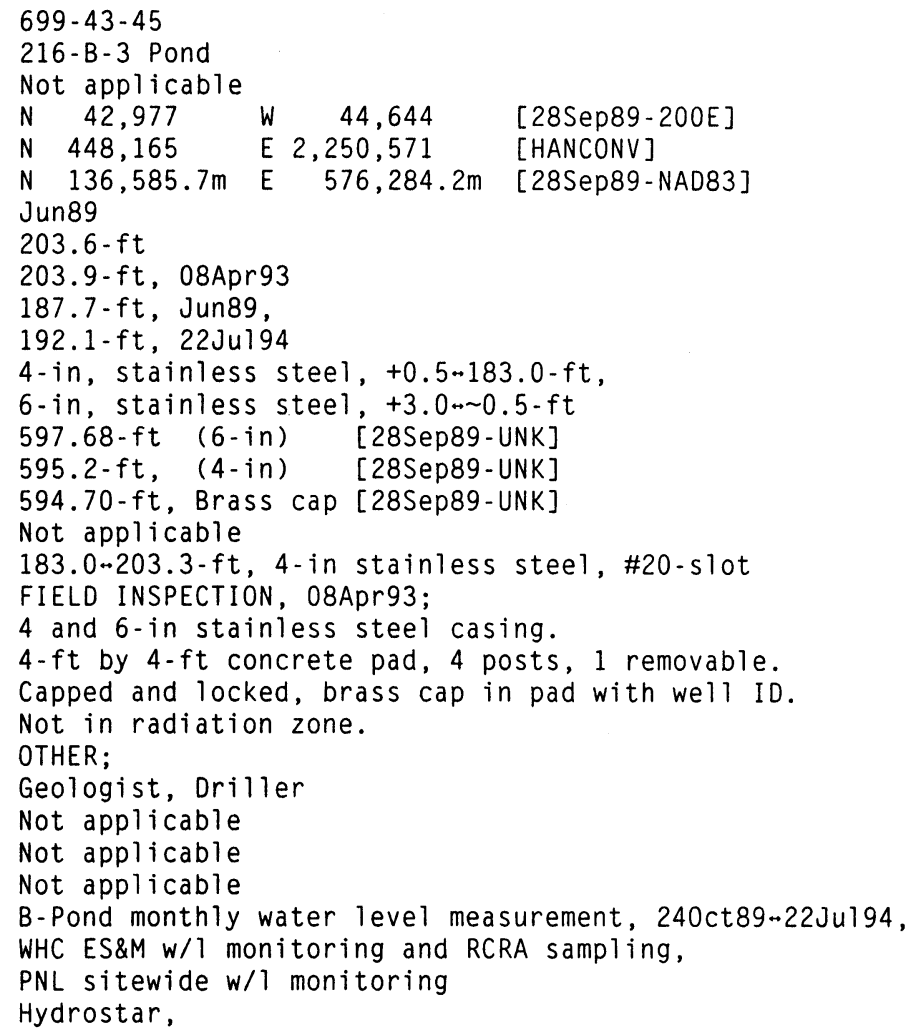




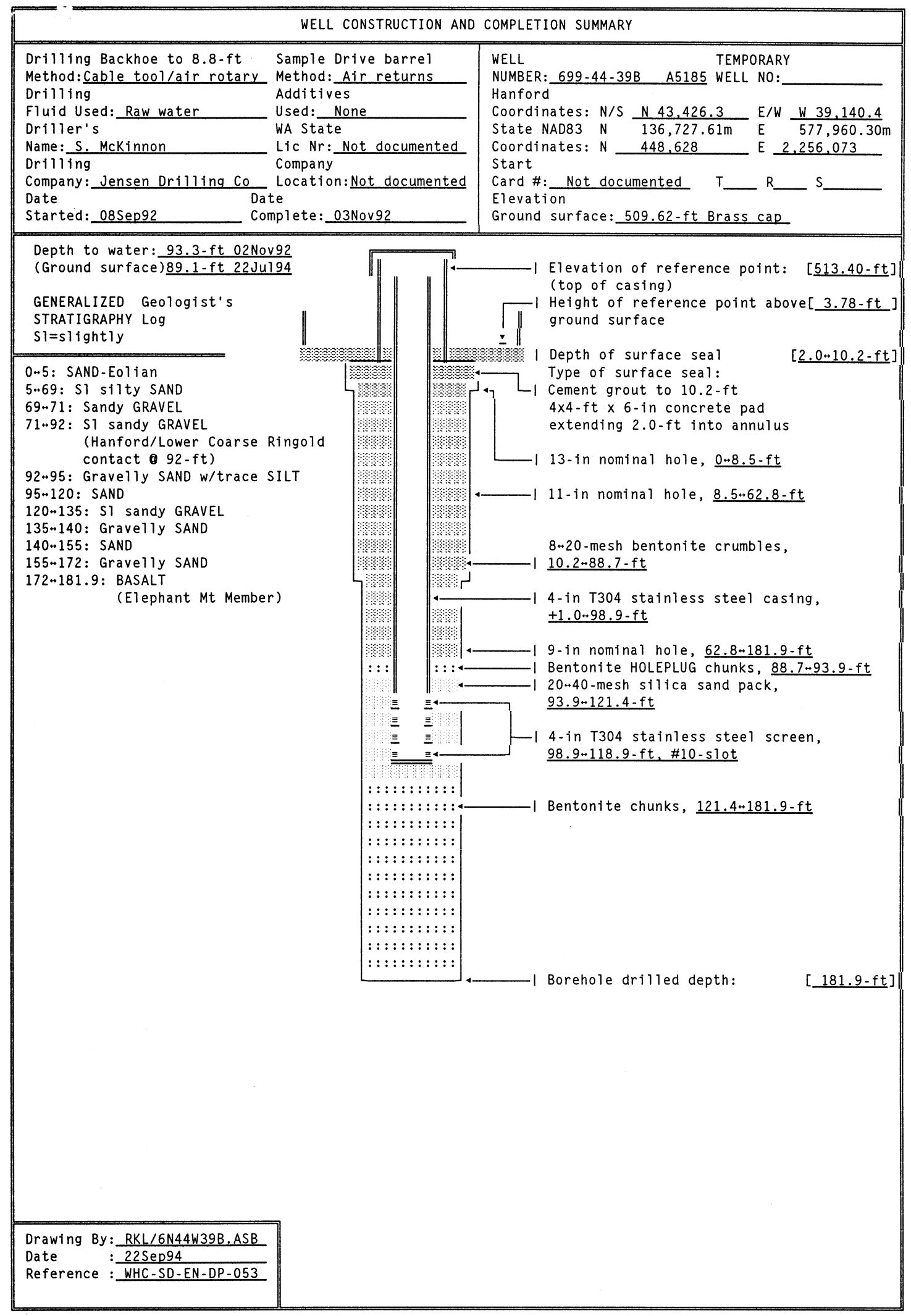




\section{SUMMARY OF CONSTRUCTION DATA AND FIELD OBSERVATIONS \\ RESOURCE PROTECTION WELL - 699-44-39B}

WELL DESIGNATION
CERCLA UNIT
RCRA FACILITY
HANFORD COORDINATES
LAMBERT COORDINATES
DATE DRILLED
DEPTH DRILLED (GS)
MEASURED DEPTH (GS)
DEPTH TO WATER (GS)
CASING DIAMETER
ELEV TOP CASING
ELEV GROUND SURFACE
PERFORATED INTERVAL
SCREENED INTERVAL :
COMMENTS

AVAILABLE LOGS TV SCAN COMMENTS DATE EVALUATED EVAL RECOMMENDATION : LISTED USE CURRENT USER PUMP TYPE MAINTENANCE
$699-44-39 B$

Not applicable 216 B-3 Pond 


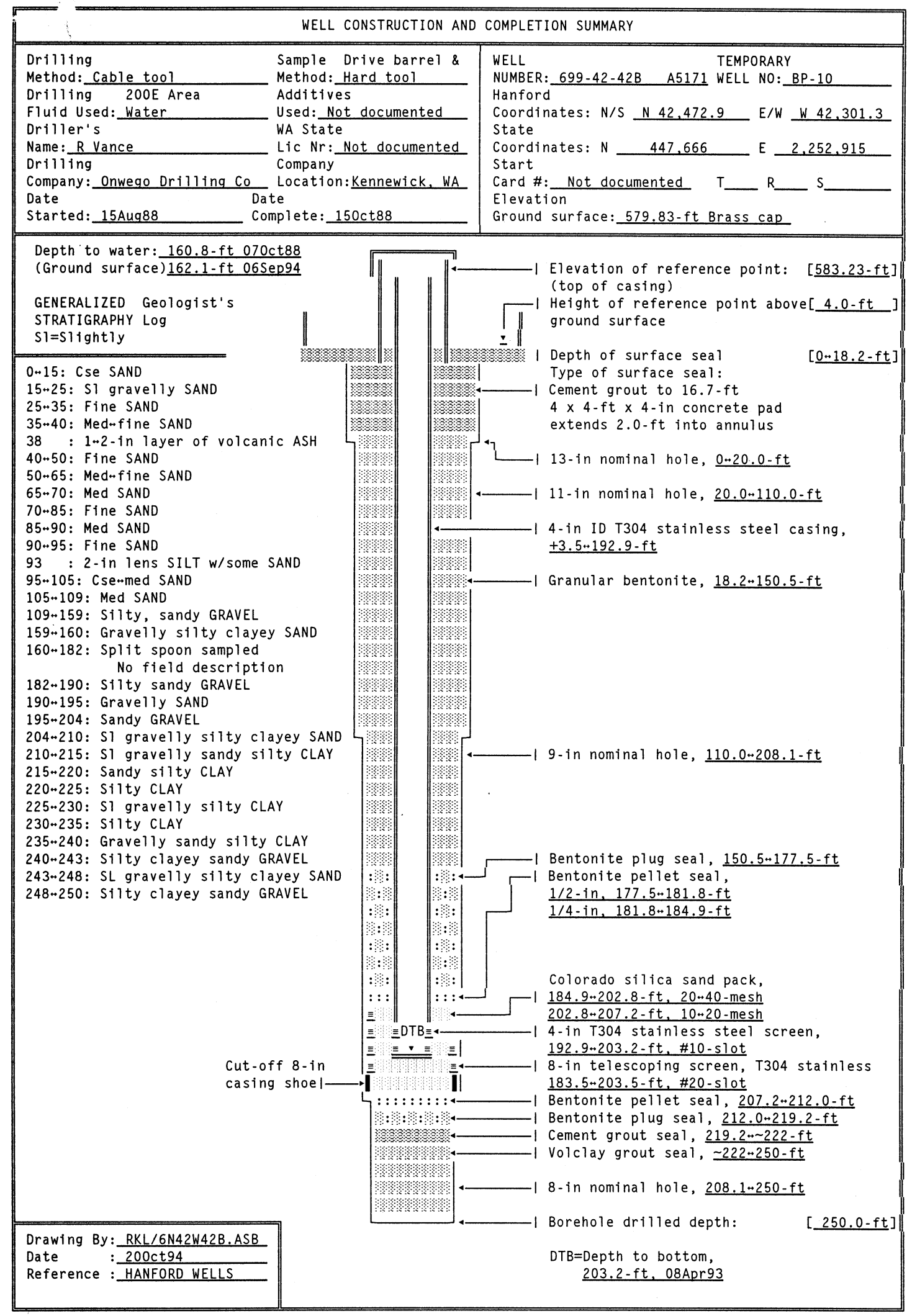




\section{SUMMARY OF CONSTRUCTION DATA AND FIELD OBSERVATIONS RESOURCE PROTECTION WELL - 699-42-42B}

WELL DESIGNATION
RCRA FACILITY
CERCLA UNIT
HANFORD COORDINATES
LAMBERT COORDINATES :
DATE DRILLED
DEPTH DRILLED (GS)
MEASURED DEPTH (GS)
DEPTH TO WATER (GS) :
CASING DIAMETER :
ELEV TOP CASING :
ELEV GROUND SURFACE :
PERFORATED INTERVAL :
SCREENED INTERVAL :
COMMENTS

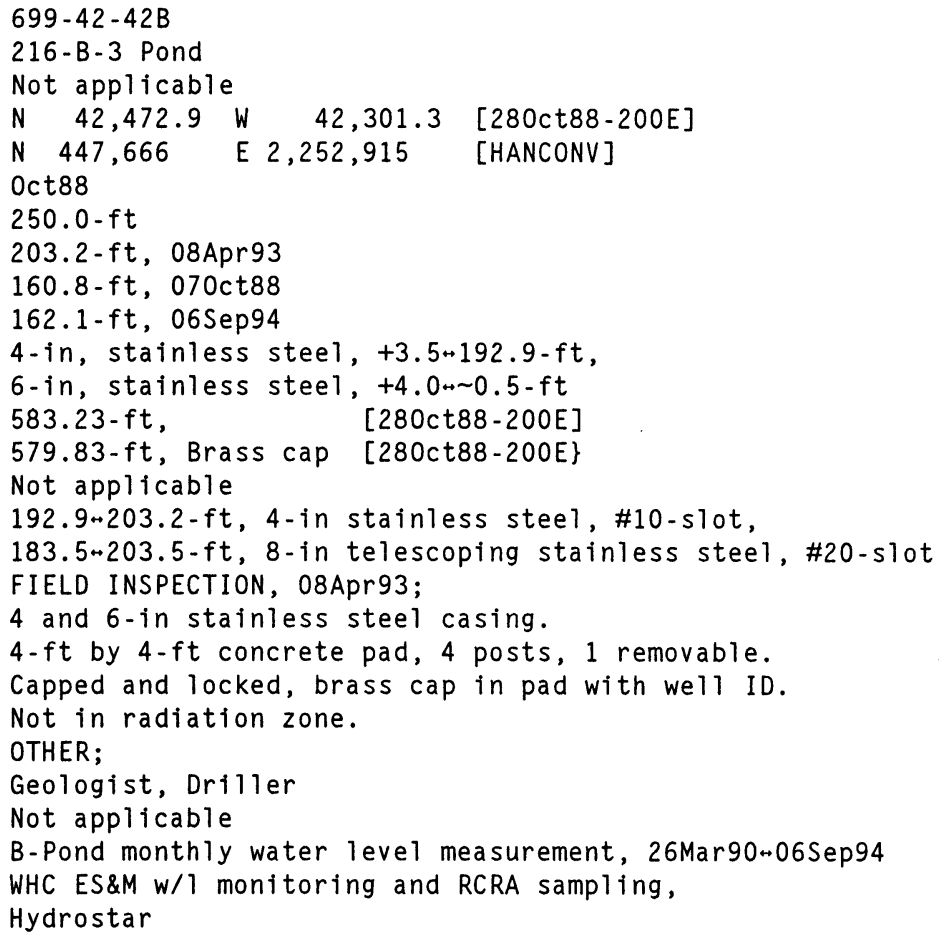




\section{Distribution}

No. of

Copies

ONSITE

4 DOE Richland Operations Office

M. J. Furman

R. D. Hildebrand

A5-13

H0-12

$\mathrm{H} 0-12$

K. M. Thompson

A. C. Tortoso

U.S. Environmental Protection Agency

D. A. Faulk

B5-01

Bechtel Hanford, Inc.

G. B. Mitchem

H0-2 1
No. of

Copies

2 CH2M HILL Hanford, Inc.
J. V. Borghese
H0-19
L. C. Swanson
H9-02

Washington State Department of Ecology

W. Soper

B5-18

20 Pacific Northwest National Laboratory

D. B. Barnett (5) K6-81

C. J. Chou K6-81

E. P. Dresel K6-96

M. J. Hartman K6-96

S. P. Luttrell K6-96

R. M. Smith K6-96

D. L. Stewart K6-96

D. Vela K6-96

B. A. Williams K6-81

Information Release Office (7) K1-06 